KJELD AAGAARD JAKOBSEN

\title{
RELAÇÕES TRANSNACIONAIS E O FUNCIONAMENTO DO REGIME TRABALHISTA INTERNACIONAL
}

Dissertação apresentada a Faculdade de Filosofia, Letras e Ciências Humanas da Universidade de São Paulo para obtenção do título de Mestre em Ciência Política.

Área de Concentração: Relações Internacionais.

Orientadora: Prof. Dra. Rossana Rocha Reis.

São Paulo

2009 
KJELD AAGAARD JAKOBSEN

\section{RELAÇÕES TRANSNACIONAIS E O FUNCIONAMENTO DO REGIME}

TRABALHISTA INTERNACIONAL

Dissertação apresentada a Faculdade de Filosofia, Letras e Ciências Humanas da Universidade de São Paulo para obtenção do título de Mestre em Ciência Política.

Área de Concentração: Relações Internacionais.

Orientadora: Prof. Dra. Rossana Rocha Reis.

São Paulo

2009 
AUTORIZO A REPRODUÇÃO E DIVULGAÇÃO TOTAL OU PARCIAL DESTE TRABALHO, POR QUALQUER MEIO CONVENCIONAL OU ELETRÔNICO, PARA FINS DE ESTUDO E PESQUISA, DESDE QUE CITADA A FONTE.

Catalogação na Publicação

Serviço de Documentação de Ciência Política

Faculdade de Filosofia, Letras e Ciências Humanas da Universidade de São Paulo

Jakobsen, Kjeld Aagaard.

Relações Transnacionais e o Funcionamento do Regime trabalhista Internacional/ Kjeld Aagaard Jakobsen; orientadora Rossana Rocha Reis.

-- São Paulo, 2009.

$154 \mathrm{f}$.

Dissertação de Mestrado - Programa de Pós-Graduação em Ciência Política. Área de concentração: Relações Internacionais. Faculdade de Filosofia, Letras e Ciências Humanas da Universidade de São Paulo.

1. Relações Transnacionais. 2. Regime Trabalhista Internacional. 3. Movimento Sindical. I. Título.

CDD 


\section{FOLHA DE APROVAÇÃO}

\section{Kjeld Aagaard Jakobsen}

Relações transnacionais e o funcionamento do regime trabalhista internacional.

Dissertação apresentada a Faculdade de Filosofia, Letras e Ciências Humanas da Universidade de São Paulo para obtenção de título de Mestre em Ciência Política.

Área de concentração: Relações Internacionais.

Aprovado em: ___ de ____ de 2009.

Banca Examinadora:

Prof. Dr.

Instituição Assinatura

Prof. Dr.

Instituição Assinatura

Prof. Dr.

Instituição Assinatura

Prof. Dr. Instituição Assinatura 


\section{DEDICATÓRIA}

A minha amada esposa e companheira Leonor que sempre me incentiva a dar um passo além. Aos queridos filhas, filhos e neto Liv, Jade, Vladimir, Vinicius e Enzo e mães "Mor" e D. Leonor que sempre apostam que tudo vai dar certo. 


\section{LISTA DE SIGLAS}

ABNT Associação Brasileira de Normas Técnicas

ABONG Associação Brasileira de Organizações Não-Governamentais

AFL-CIO American Federation of Labour - Congress of Industrial Organizations

AIT

Associação Internacional de Trabalhadores

ALCA

Área de Livre Comércio das Américas

APEC

Asia Pacific Economic Cooperation

BIAC

Business and Industry Advisory Committee

BIRD

Banco Internacional de Reconstrução e Desenvolvimento

CBTU

Coalition of Black Trade Unionists

$\mathrm{CCC}$

Clean Clothes Campaign

CCSCS Coordenadora de Centrais Sindicais do Cone Sul

CE Comunidade Européia

CEAL Coalizão Empresarial da América Latina

CECA Comunidade Européia do Carvão e do Aço

CEE Comunidade Econômica Européia

CES Confederação Européia de Sindicatos

CIOSL Confederação Internacional das Organizações Sindicais Livres

CISC Confederação Internacional de Sindicatos Cristãos

CISA Confederação Internacional de Sindicatos Árabes

CJM Coalizão para Justiça nas "Maquillas"

CLAT Confederação Latino-Americana do Trabalho

CMC Conselho de Mercado Comum

CMT Confederação Mundial do Trabalho

CSA Confederação Sindical das Américas

CSI Confederação Sindical Internacional

Cusfta Canada United States Free Trade Agreement

CUT Central Única dos Trabalhadores

ECOSOC Economic and Social Committee

EMN Empresa Multinacional 


\begin{tabular}{|c|c|}
\hline FCES & Fórum Consultivo Econômico e Social \\
\hline FIJ & Federação Internacional de Jornalistas \\
\hline FITCM & Federação Internacional de Trabalhadores na Construção e Madeira \\
\hline FITIM & Federação Internacional de Trabalhadores na Indústria de Metal \\
\hline FMI & Fundo Monetário Internacional \\
\hline FSC & Forest Stewardship Certification \\
\hline FSI & Federação Sindical Internacional \\
\hline FSM & Federação Sindical Mundial \\
\hline FTTVC & Federação Internacional de Trabalhadores Têxteis, Vestuário e Couro \\
\hline GATT & General Agreement on Trade and Tariffs \\
\hline GMC & Grupo Mercado Comum \\
\hline GRI & Global Reporting Initiative \\
\hline IBASE & Instituto Brasileiro de Análises Sócio-Econômicos \\
\hline IBGE & Instituto Brasileiro de Geografia e Estatística \\
\hline \multirow[t]{2}{*}{ ICEM } & Federação Internacional de Trabalhadores na Química, Energia e \\
\hline & Indústrias Diversas \\
\hline IDEC & Instituto de Defesa do Consumidor \\
\hline IE & Internacional da Educação \\
\hline IED & Investimento Externo Direto \\
\hline IFC & Internacional Finance Corporation \\
\hline INSPIR & Instituto Sindical Interamericano Pela Igualdade Racial \\
\hline IOS & Instituto Observatório Social \\
\hline ISO & International Standard Organization \\
\hline ISP & Internacional dos Serviços Públicos \\
\hline ITF & Federação Internacional dos Trabalhadores em Transporte \\
\hline Mercosul & Mercado Comum do Sul \\
\hline NAAEC & North American Agreement on Environment Cooperation \\
\hline NAALC & North American Agreement on Labour Cooperation \\
\hline NAFTA & North American Free Trade Agreement \\
\hline NAO & National Administrative Office \\
\hline NIC & New Industrialized Country \\
\hline
\end{tabular}




\begin{tabular}{|c|c|}
\hline OCDE & Organização para a Cooperação e Desenvolvimento Econômico \\
\hline OECE & Organização Européia para a Cooperação Econômica \\
\hline OI & Organização Internacional \\
\hline OIC & Organização Internacional de Comércio \\
\hline OIE & Organização Internacional de Empregadores \\
\hline OIT & Organização Internacional do Trabalho \\
\hline OMC & Organização Mundial do Comércio \\
\hline ONG & Organização Não-Governamental \\
\hline ONGI & Organização Não-Governamental Internacional \\
\hline ONU & Organização das Nações Unidas \\
\hline ORIT & Organização Regional Interamericana de Trabalhadores \\
\hline OUA & Organização da Unidade Africana \\
\hline OUSA & Organização da Unidade Sindical Africana \\
\hline $\mathrm{PCN}$ & Ponto de Contato Nacional \\
\hline PEA & População Economicamente Ativa \\
\hline PERC & Confederação Sindical Pan-Européia \\
\hline PG & Pacto Global \\
\hline PIB & Produto Interno Bruto \\
\hline RSE & Responsabilidade Social Empresarial \\
\hline SA & Social Accountability \\
\hline SADEC & South African Development and Economic Cooperation \\
\hline SAI & Social Accountability International \\
\hline SEWA & Self Employed Women Association \\
\hline SGP & Sistema Geral de Preferências \\
\hline SIGTUR & Southern Initiative on Globalization and Trade Union Rights \\
\hline SOMO & Centre for Investigation on Multinational Corporations \\
\hline TEC & Tarifa Externa Comum \\
\hline TUAC & Trade Union Advisory Committee \\
\hline UAW & United Auto Workers \\
\hline $\mathrm{UE}$ & União Européia \\
\hline UIS & União Internacional de Sindicatos \\
\hline
\end{tabular}


UITA União Internacional de Trabalhadores em Alimentação, Agricultura, Hotéis, Restaurantes, tabaco e Afins

UNI Union Network

Unctad United nations Conference on Trade and Development

UNICE União de Confederaçãoes Europeus de Indústrias e Empresas

ZPE Zona de Processamento de Exportação 


\section{SUMÁRIO}

1 INTRODUÇÃO 19

2 GLOBALIZAÇÃO E A DIVISÃO DO TRABALHO 32

2.1 Introdução 32

$2.2 \mathrm{O}$ desenvolvimento industrial e a divisão do trabalho 35

2.3 A globalização e a atuação das empresas multinacionais $\quad 50$

2.4 A divisão do trabalho na era da globalização 53

2.5 O paradigma neoliberal: "Estado Mínimo" e redução de direitos 58

3 O REGIME TRABALHISTA INTERNACIONAL 62

3.1 Introdução

$\begin{array}{ll}3.2 \mathrm{O} \text { regime trabalhista internacional Estado-centrado } & 67\end{array}$

3.2.1 A OIT e as Normas Fundamentais de Trabalho 68

3.2.2 As Diretrizes para Empresas Multinacionais da OCDE 73

3.2.3 O regime trabalhista internacional nos acordos de integração regional $\quad 75$

3.3 As iniciativas para fortalecer o arranjo estatal do regime trabalhista internacional 84

3.3.1 A discussão sobre comércio e direitos trabalhistas 85

$\begin{array}{ll}\text { 3.3.2 As iniciativas para fortalecer a OIT } & 89\end{array}$

3.4 O regime trabalhista internacional e seu arranjo privado 92

3.4.1 Responsabilidade Social Empresarial (RSE) 93

3.4.2 A ISO 26.000

3.4.3 O SA $8.000 \quad 96$

3.4.4 Os códigos de conduta e os Acordos Marco Globais 97

3.5 Uma situação especial: o Pacto Global da ONU 98

4 AS RELAÇÕES TRANSNACIONAIS E OS ATORES SOCIAIS 100

$\begin{array}{ll}4.1 \text { Introdução } & 100\end{array}$

4.2 As relações transnacionais 106

4.3 O Movimento Social: organizações sociais e não-governamentais 110

$\begin{array}{ll}4.4 \text { As organizações sindicais } & 114\end{array}$

$\begin{array}{ll}4.5 \text { As empresas } & 122\end{array}$

4.6 As interações entre os atores sociais e sindicais 125

5 AS INICIATIVAS PARA MUDAR A POLÍTICA TRABALHISTA DAS 
EMPRESAS

5.1 Introdução 129

$\begin{array}{ll}5.2 \text { Os limites da coerção estatal } & 131\end{array}$

$\begin{array}{ll}5.3 \text { Os limites das iniciativas privadas unilaterais } & 136\end{array}$

5.4 As ações do movimento social em defesa do regime trabalhista internacional 146

6 CONCLUSÃO 154

7 REFERÊNCIAS BIBLIOGRÁFICAS 159 


\section{RESUMO}

JAKOBSEN, K.A. Relações Transnacionais e o funcionamento do regime trabalhista internacional, 2009, 154f.

Dissertação (Mestrado). Faculdade de Filosofia, Letras e Ciências Humanas, Universidade de São Paulo, São Paulo, 2009.

A mudança do paradigma produtivo, adotado após a segunda guerra mundial, começou nos anos 1970 e provocou fortes impactos na economia, na política e no mercado de trabalho mundialmente. Mais países e trabalhadores se vincularam às cadeias produtivas globais das empresas multinacionais, mas as condições de trabalho decaíram em comparação com o paradigma anterior e em vários países até mesmo as normas fundamentais de trabalho passaram a ser violadas de forma constante. Estas normas, que compõem o regime trabalhista internacional, emanam da Organização Internacional do Trabalho. Uma vez ratificadas pelos seus países membros, cabe a eles fazê-las cumprir por intermédio da sua legislação e poder coercitivo. Uma série de reformas do Estado reduziu este poder e levou os sindicatos a buscarem mecanismos supranacionais para defender as normas de trabalho e esta pesquisa se propõe a analisar os efeitos da atuação transnacional dos sindicatos sobre o regime internacional do trabalho, com ênfase sobre os arranjos públicos e privados que o compõem.

Palavras-chave:- normas fundamentais de trabalho, regimes internacionais, atores sociais, arranjos Estado-centrados e arranjos privados. 


\begin{abstract}
JAKOBSEN, K.A. Relações Transnacionais e o funcionamento do regime trabalhista internacional, 2009, $154 \mathrm{f}$.

Dissertação (Mestrado). Faculdade de Filosofia, Letras e Ciências Humanas, Universidade de São Paulo, São Paulo, 2009.

The productive paradigm adopted after the Second World War started to change in the 1970'ies and provoked strong impacts on the world economy, its politics as well as the labor market. More countries and workers engaged with multinational corporations' global production chains but the labor conditions declined in comparison with the former paradigm and even core labor standards got constantly violated in several countries. These norms arise from the International Labor Organization and are part of the labor regime. Once ratified by its member countries it's up to them to enforce their accomplishment through their legislations and coercive power. However some state reforms reduced this power and led the trade unions to seek for supranational mechanisms to defend the labor standards and this research aims to analyze the effects of the unions' transnational relations on the international labor regime with emphasis on its public and private arrangements.
\end{abstract}

Keywords: core labor Standards, international regimes, social actors, State-centered arrangements and private arrangements. 


\section{INTRODUÇÃO}

A evolução do capitalismo a partir da primeira revolução industrial na segunda metade do século XVIII já tinha como uma de suas características a divisão do trabalho na produção manufaturada como forma de estimular a especialização, aumentar a destreza e a produtividade, reduzir o custo da mão de obra e maximizar os lucros.

Os paradigmas produtivos introduzidos posteriormente mantiveram a divisão do trabalho, mas se utilizaram de novas tecnologias e métodos de trabalho para aumentar a padronização e a produtividade, como por exemplo, o "Fordismo" que introduziu a fabricação em série por meio de linhas de produção.

O paradigma produtivo "Fordista" e o "Sistema de Bretton Woods", estabelecidos após a segunda guerra mundial, entraram em crise a partir da década de 1970. Além dos impactos que isto provocou na economia e na política internacional também gerou profundas transformações estruturais no mercado de trabalho que repercutem até os dias atuais.

O novo paradigma que substituiu o modelo "Fordista" desenvolveu-se com base no destacado progresso tecnológico, principalmente, dos meios de transporte e comunicação e ampliou ainda mais a produtividade por meio da descentralização da produção, redução de capital empatado em estoques e eliminação dos tempos de trabalho ociosos.

As corporações multinacionais se expandiram em proporção geométrica a partir deste momento e implementaram um novo modo de produção e divisão do trabalho que requer flexibilidade nos contratos de mão de obra e também a descentralização da produção por intermédio de "outsourcing” (terceirização) que jogam os possíveis riscos e prejuízos do 
sistema sobre os ombros dos trabalhadores e das empresas subcontratadas. (Chesnais, 1996).

A terceirização é um mecanismo que aprofunda a divisão do trabalho e ainda está em processo de expansão. Ela reproduz a tradicional separação entre trabalho intelectual e manual ao colocar de um lado, uma minoria de trabalhadores mais capacitados tecnologicamente, melhor remunerados, com acesso a maiores benefícios sociais e possuidores de maior estabilidade de emprego e, de outro, uma ampla maioria de subcontratados com menor capacitação profissional, menores salários e benefícios sociais e, muitas vezes sujeitos a condições precárias de trabalho. Além destes dois, há ainda um terceiro grupo expressivo composto por trabalhadores desempregados, precarizados e informais que em muitos países em desenvolvimento, ultrapassa metade da População Economicamente Ativa (PEA).

O novo paradigma e o acirramento da competitividade no mercado mundial fazem parte de um movimento das empresas multinacionais pela redução dos custos de produção, particularmente, a mão de obra, pois esta nova divisão do trabalhou não se limita apenas às empresas no interior dos Estados Nacionais, mas se estende também às cadeias produtivas internacionais.

Nos países industrializados, isso implicou em redução de empregos e salários, bem como na perda de direitos sociais tradicionais. No caso dos países em vias de industrialização como o Brasil, Coréia do Sul, entre outros, também representou a piora das condições de trabalho daqueles que já estavam integrados à industrialização nascente, porém somada ao crescimento do trabalho informal e à exclusão social. Em alguns países que se inseriram diretamente neste modelo de globalização, a exemplo da China, significou 
a adoção de condições e direitos trabalhistas precários, muito semelhantes aos do início da industrialização dos países desenvolvidos.

Esse recrudescimento da violação de direitos, por ter abrangência internacional, é enfrentada pelos sindicatos por meio da tentativa de criar instrumentos de proteção aos direitos trabalhistas, sociais e ambientais em âmbito supra-nacional para compensar o enfraquecimento ou o desaparecimento dos mecanismos reguladores nacionais.

As más condições de trabalho e ausência de direitos trabalhistas caracterizaram os primórdios da industrialização e estimularam a criação de sindicatos como instrumentos de conquista de direitos e de defesa contra os abusos.

Estes, de fato, jogaram um papel fundamental neste sentido. O período de vigência do modelo de produção "Fordista" também marcou o desenvolvimento de um abrangente "Estado de Bem Estar Social”, embora limitado basicamente aos países industrializados onde a aliança tácita entre os partidos social democratas no poder e os sindicatos exerceu uma contribuição decisiva.

Paradoxalmente, alguns empresários ainda no início da industrialização concluíram que a redução de custos por meio da ausência de direitos ou da violação daqueles eventualmente existentes representava um fator de competitividade desleal. Por exemplo, Daniel Le Grand, um industrial francês, entre 1840 e 1853, reiteradamente solicitou aos governos europeus que promulgassem uma legislação trabalhista comum para eliminar a concorrência entre as empresas. Ele apresentou vários projetos de leis internacionais versando sobre jornada de trabalho, trabalho noturno, atividades insalubres ou perigosas e regulamentação do trabalho de crianças (OIT, 1998).

Ativistas sindicais também se mobilizaram na segunda metade do século XIX na tentativa de aplicar um tratamento supranacional para as questões relacionadas ao mundo 
do trabalho como demonstra a fundação da I Internacional dos Trabalhadores e, posteriormente, de algumas federações internacionais de trabalhadores de diversos setores industriais como os da metalurgia, têxteis, couros, entre outros.

Por fim na mesma época ocorreram alguns eventos governamentais para discutir a situação do trabalho, particularmente penoso nas fábricas e minas da Europa e América do Norte, com o intuito de estabelecer um mínimo de regulamentação e proteção laboral por meio de normas internacionais. A cooperação entre os Estados Nacionais no campo das relações de trabalho ocorreu na prática com a criação da Organização Internacional do Trabalho (OIT) em 1919. Esta iniciativa ocorreu no bojo do Tratado de Versalhes que formalizou o fim da Primeira Guerra Mundial a partir do acúmulo de discussões sobre normas trabalhistas internacionais ocorridas na segunda metade do século XIX.

A OIT se tornou uma instituição especializada com participação de governos, empresários e trabalhadores na sua gestão e suas primeiras convenções trataram de temas recorrentes das reivindicações sindicais como a regulamentação da jornada diária de trabalho, idade mínima para o trabalho na indústria, proteção à maternidade, entre outros direitos que foram discutidos e aprovados nas conferências anuais de trabalho.

A organização cumpriu um mandato importante a partir do fim da Segunda Guerra Mundial em 1945 com a aprovação de uma série de convenções fortemente vinculadas a várias cláusulas da Declaração de Direitos Humanos da Organização das Nações Unidas (ONU), em particular a liberdade sindical, o direito à negociação coletiva, a proibição de discriminação de qualquer espécie no local de trabalho e a idade mínima para o trabalho.

A maioria das convenções aprovadas entre o final da década de 1940 e o início da década de 1970 mantinha coerência com as políticas de bem estar social em evolução na 
maioria dos países industrializados durante os "30 anos dourados" do capitalismo e elas geralmente também tinham o apoio dos governos dos países de regime socialista.

No entanto, diante das profundas transformações que ocorreram no mercado de trabalho mundial, principalmente, com a adoção por vários governos do ideário neoliberal do Estado Mínimo a partir do final dos anos 1970, bem como redução de direitos sociais ao lado do poder crescente das empresas multinacionais, o regime trabalhista administrado pela OIT revelou-se insuficiente e os sindicatos procuraram novos espaços institucionais visando fortalecer o cumprimento de direitos trabalhistas em nível supranacional.

Desde a conclusão da Rodada Tóquio do Acordo Geral de Comércio e Tarifas (GATT na sigla em inglês) em 1979 até a primeira conferência da Organização Mundial do Comércio (OMC) em Cingapura em 1996, o governo americano propôs vincular o respeito às normas fundamentais de trabalho às regras internacionais de comércio (Martinez, 2002). Apesar de representar uma forma de proteger os interesses comerciais dos EUA, a iniciativa foi vista pelo movimento sindical, principalmente dos países industrializados, como uma oportunidade de utilizar o poder da OMC de aplicar sanções comerciais para fortalecer o respeito pelos direitos dos trabalhadores, particularmente, nos países em desenvolvimento onde, em tese, seriam mais desrespeitados.

Esta proposta nunca alcançou consenso, sob o argumento do risco protecionista e de que a instituição apropriada para lidar com as normas de trabalho é a OIT. No entanto, vários acordos comerciais negociados posteriormente pelos EUA, como o "North American Free Trade Agreement" (Nafta) com o Canadá e o México e bilaterais com o Chile, Peru, entre outros, bem como os critérios para aplicação do Sistema Geral de Preferências (SGP) incluíram cláusulas que permitem pressionar os governos destes países para que, no mínimo, respeitem a própria legislação trabalhista nacional. 
Recentemente, até o "International Finance Corporation" (IFC), uma das instituições do Grupo Banco Mundial (BIRD) incluiu o respeito pelas Normas Fundamentais de Trabalho como um dos critérios a serem seguidos para conceder empréstimos.

Também surgiram algumas iniciativas eminentemente privadas de políticas de responsabilidade social empresarial como a "Social Accountability International" (SAI) e sua norma SA 8000, bem como a "International Standard Organization" (ISO) e sua norma 26.000 que entrará em vigor em 2010. Ambas incluem o cumprimento de direitos fundamentais previstos pela OIT.

Tanto a SA quanto a ISO são entidades privadas que administram e supervisionam políticas padronizadas que podem tratar de diferentes temas como meio ambiente, segurança no trabalho, qualidade na produção, tecnologia ou, no caso da SA 8000 e ISO 26000, também "standards" (padrões) sociais e trabalhistas. A adoção destes padrões por uma empresa é voluntária, mas para que ela receba a certificação de que cumpre as diretrizes previstas no "standard" deve se submeter a uma avaliação prévia e eventualmente modificar seus procedimentos. A entidade gestora do "padrão" SA ou ISO poderá realizar um acompanhamento periódico posterior para assegurar que a empresa em questão respeite as diretrizes sob pena, em caso contrário, de perder o certificado. Algumas empresas consideram vantajoso poder se apresentar diante dos consumidores de seus produtos como “ambientalmente ou socialmente" responsáveis e a certificação da SA ou da ISO representa um comprovante externo do seu respeito pelo compromisso assumido.

No âmbito da ONU, entre as várias medidas que fazem parte da "Declaração do Milênio" de 1.999 incluiu-se o "Pacto Global" que é um mecanismo de estímulo às empresas para cumprirem voluntariamente determinados padrões de direitos humanos, 
trabalhistas e ambientais, bem como aderirem à Convenção Anti-Corrupção das Nações Unidas. O "Pacto" é um arranjo particular porque nasce da aprovação dos Estados Nacionais no âmbito de uma organização internacional, mas não atribui nenhuma responsabilidade aos mesmos Estados pelo seu cumprimento e tampouco exige qualquer tipo de certificação ou monitoramento externo de caráter privado.

Seja qual for o arranjo, centrado no Estado ou no setor privado, o conteúdo dos padrões e normas trabalhistas é basicamente o pleno respeito à liberdade sindical e ao direito à negociação coletiva; a proibição do trabalho infantil, trabalho escravo e a discriminação de qualquer natureza no mercado de trabalho (Scherrer e Greven, 2001).

No entanto, o poder coercitivo das Organizações Internacionais (OI) às quais as normas se vinculam, é apenas moral. Nos casos da OIT e suas Convenções e da Organização para a Cooperação e o Desenvolvimento Econômico (OCDE) e suas "Diretrizes para Empresas Multinacionais", a responsabilidade de garantir o respeito por estas normas é transferida para os Estados Nacionais, pois se supõem que estes possuem poder de coerção para tanto.

No caso dos arranjos privados como a SA 8000 e a futura ISO 26000, as empresas que as adotam são responsáveis pelo seu cumprimento, pois a adesão às suas orientações é voluntária. Entretanto, para que haja reconhecimento público da sua adesão às práticas éticas na produção, elas, não apenas assumem o compromisso de se submeter a um mecanismo de certificação, como necessitam fazê-lo para comprovar que de fato as cumprem. Isto pressupõe a necessidade de algum tipo de monitoramento, público ou privado, e, portanto, o "bem comum" que os padrões trabalhistas representam, deixa de ser assegurado somente por intermédio do Estado e abre caminho para a incidência do movimento social e sindical. 
Embora o Estado detenha o monopólio do legítimo poder de coerção, freqüentemente, verificamos que seu poder coercitivo não é aplicado com o mesmo rigor no interior das fronteiras nacionais quando comparamos as situações de violação da legislação trabalhista com as da violação de outras leis. Além disso, há expressivas diferenças na qualidade dos direitos trabalhistas entre um país e outro.

No aspecto supranacional não há monopólio do poder coercitivo, salvo quando os Estados Nacionais o delegam às OIs, em circunstâncias especiais e limitadas como o poder de sanção econômica e militar do Conselho de Segurança da ONU e as sanções comerciais da OMC.

No caso da violação de direitos trabalhistas nas cadeias produtivas internacionais, ela não é considerada uma justificativa para aplicação de medidas coercitivas rigorosas em nível internacional e, inclusive, este tipo de violação gera menor sensação de urgência na opinião pública em comparação com o desrespeito aos direitos civis e políticos e ao meio ambiente.

Diante da insuficiência do regime trabalhista internacional em garantir o respeito aos direitos amplos e universais devido à ausência de instrumentos coercitivos no nível supranacional e também devido ao enfraquecimento do papel dos Estados Nacionais em garantir o respeito pelas normas fundamentais de trabalho, esta dissertação se propõe a verificar, a partir de diferentes iniciativas, se a atuação transnacional de determinados atores políticos, principalmente os sindicatos, podem fortalecer o regime trabalhista internacional e contribuir para ampliar a eficácia dos seus diferentes arranjos públicos e privados.

A hipótese da pesquisa é a de que estes elementos podem advir de uma combinação das normas emanadas de organizações internacionais cujo poder coercitivo é de responsabilidade dos Estados Nacionais com outros mecanismos de fortalecimento destas 
normas disponibilizados pelos arranjos privados, como, por exemplo, o monitoramento de empresas e campanhas sindicais pelo cumprimento de seus compromissos.

Para abarcar este conteúdo, a dissertação será dividida em quatro capítulos, além da introdução e da conclusão conforme segue.

O primeiro capítulo discutirá as mudanças ocorridas na divisão do trabalho com foco prioritário para o paradigma atual da acumulação capitalista flexível no período pós fordista (Harvey, 1990) ou produção flexível (Castells, 1999) e suas consequiências para o mundo do trabalho no tocante aos direitos sociais e trabalhistas básicos.

A discussão sobre a aplicação dos direitos fundamentais de trabalho na dissertação referir-se-á principalmente às companhias multinacionais e suas cadeias produtivas internacionais por serem responsáveis por exemplos marcantes de violações dos mesmos. Isto decorre, em grande parte, porque se utilizam de expressiva mão de obra subcontratada por meio de empresas "terceiras" que geralmente dão pouca atenção às normas fundamentais de trabalho e também por alocarem parcelas importantes de sua produção, propositalmente, em países em desenvolvimento onde os padrões trabalhistas e ambientais são rebaixados ou inexistentes (Chesnais, 1996).

Se as corporações multinacionais violam os direitos, a solução passaria pelo exercício da soberania e do poder coercitivo dos Estados, em particular frente a essas empresas (Pease, 2003). No entanto, este poder se debilitou ao longo dos anos de ajustes estruturais e os Estados Nacionais tiveram sua capacidade reguladora reduzida.

Além disso, como o capital possui grande mobilidade atualmente, ele procura os locais onde as restrições para produzir sejam menores. Desta forma, muitos governos hesitam em elevar os padrões trabalhistas e ambientais temerosos de perder investimentos produtivos. 
A acumulação flexível, a formação das cadeias produtivas globais descritas por Dupas (1999), o "Estado Mínimo" e a crescente violação dos direitos trabalhistas em partes importantes destas cadeias geram a busca pela padronização de normas trabalhistas em âmbito global para que as empresas tenham que respeitá-las em qualquer país.

Isto introduz a importância do regime trabalhista internacional, sua conceituação e seus diferentes arranjos, particularmente, a distinção entre o funcionamento do seu arranjo tradicional centrado no Estado, de "cima para baixo" e os arranjos com maior influência de atores privados, já mencionados anteriormente, de "baixo para cima". Isso será desenvolvido no segundo capítulo.

Este capítulo começará por discutir se é possível considerar a existência de um regime trabalhista internacional no âmbito da governança global e descreverá o conteúdo das Normas, Recomendações e Declarações da OIT, das Diretrizes para Empresas Multinacionais da OCDE, dos acordos e protocolos sociais ligados aos acordos regionais de comércio, do SA 8.000, do ISO 26.000, dos Códigos de Conduta e dos Acordos Marco Globais, bem como os procedimentos para a sua aplicação e as iniciativas adotadas para fortalecer o arranjo Estado - centrado do regime trabalhista.

Estas iniciativas são desenvolvidas por meio de articulações transnacionais, intersindicais e, entre sindicatos e outras organizações sociais, para introduzir cláusulas de defesa dos direitos em tratados internacionais, particularmente, nos de comércio. Houve e há várias ações transnacionais e campanhas em andamento para tentar introduzir o tema trabalhista como parte do mandato negociador da $\mathrm{OMC}$ e de outros acordos de comércio e integração regionais, bem como as iniciativas para fortalecer o poder normativo da OIT e a aplicação das Diretrizes para Empresas Multinacionais da OCDE. 
O terceiro capítulo trata das relações transnacionais com vistas a ampliar a eficácia do regime trabalhista internacional, bem como da agenda e da descrição dos principais atores, das diferenças entre eles e das alianças que eventualmente realizam.

Há profundas diferenças entre organizações sindicais e outras organizações sociais, mesmo quando há convergências entre vários aspectos da estratégia supranacional para fortalecer a aplicação das normas fundamentais de trabalho ("enforcement"). Primeiro, pela necessidade da mudança de percepções e atitudes, pois para tornar estas normas fundamentais mais eficazes, é necessário que os atores, estatais ou não, percebam a importância do "mundo do trabalho e seus direitos" e mudem de atitude em relação a eles. Esta mudança de atitude já se percebe em relação aos direitos humanos e ao meio ambiente que são hoje reconhecidos como temas importantes para a comunidade internacional, o que, por sua vez, incentiva os Estados nacionais a adotar medidas mais eficazes para defendêlos.

Em segundo lugar, no nosso caso, o ator não governamental principal que advoga a causa das normas fundamentais de trabalho é o movimento sindical internacional, embora, por motivos diferentes, haja também algumas iniciativas empresariais neste sentido, bem como de outras organizações sociais que podem, inclusive, apoiar os sindicatos. Portanto, se faz necessário identificar e qualificar este ator principal.

Atualmente, o poder no cenário internacional não advém unicamente da força militar que os países dispõem, mas também da habilidade dos atores internacionais de convencer os demais a aceitar sua posição ou de controlar o resultado final de eventuais negociações. Assim, é necessário que haja ligação entre as estratégias das organizações sociais e sindicais, construção das relações transnacionais e de sua agenda e que as organizações internacionais fortaleçam seu papel. 
A estratégia do movimento sindical internacional de incidir sobre as políticas de Estado e sobre o comportamento das empresas no tocante aos direitos sociais e trabalhistas é executada por meio de duas táticas gerais.

O capítulo quatro trata da tática para promover mudanças positivas nas relações de trabalho das empresas, particularmente, da tática efetivada pelos atores sociais e sindicais para pressionar as empresas a melhorarem seus comportamentos frente ao regime trabalhista internacional por meio de mobilizações e campanhas para convencê-las a respeitar certos direitos trabalhistas ou aprimorarem suas relações industriais.

Serão mencionadas várias destas campanhas como o "Clean Clothes Campaign" (CCC) - "Campanha por Roupas Limpas" - iniciada em 1990 para defender a melhoria das condições de trabalho no setor têxtil internacionalmente ou a campanha contra a empresa americana de calçados esportivos NIKE por terceirizar grande parte de sua produção para empresas ou para trabalhadores à domicílio na Ásia sob condições de trabalho extremamente aviltantes.

Podemos mencionar ainda as tentativas de assegurar o respeito pela legislação trabalhista nas chamadas empresas "maquillas" situadas na fronteira do México com os EUA e que montam produtos que são vendidos neste último sem impostos de importação devido ao Nafta ou a campanha mundial para pressionar a empresa mineradora Rio Tinto a respeitar a liberdade sindical e o direito às negociações coletivas na sua área de atuação.

A conclusão do trabalho procura estabelecer um balanço do resultado destas ações transnacionais em defesa dos direitos dos trabalhadores tanto na incidência sobre o regime trabalhista estatal quanto sobre o regime privado. Por exemplo, o insucesso em introduzir uma "Cláusula Social" na OMC acabou estimulando outras organizações internacionais a, de alguma forma, incluírem o respeito às normas fundamentais de trabalho no seu mandato 
e no caso da campanha frente a NIKE, a empresa acabou por adotar um código de conduta e um mecanismo de monitoramento do mesmo.

Por um lado, apesar do enfraquecimento do poder regulador do Estado Nacional, ele não deve ser desprezado. Na pior das hipóteses, é um elemento a ser combinado com outras políticas para fortalecer o regime trabalhista internacional e é também uma arena para ações políticas locais.

Por outro lado, o estabelecimento de códigos de conduta e de mecanismos de monitoramento são dois elementos chaves para assegurar um comportamento adequado das empresas que declaram voluntariamente possuir um comportamento socialmente responsável ou que foram pressionadas a respeitar as normas fundamentais de trabalho ao longo de suas cadeias produtivas.

No Brasil também há experiências concretas de algumas empresas multinacionais que, inclusive, perceberam haver vantagens em se submeter a um monitoramento externo sobre seu comportamento trabalhista e suas políticas de responsabilidade social empresarial. O temor pelo prejuízo a imagem destas empresas possibilitou a implementação de correções importantes nas falhas apontadas pelo sistema de monitoramento acordado entre elas e os sindicatos que representam seus empregados (Jakobsen, 2006).

As empresas que aplicam as normas fundamentais de trabalho e utilizam isto para aprimorar sua imagem diante do consumidor poderiam também representar um fator de indução a outras empresas.

No entanto, o consumidor necessita de uma referência para confiar se as declarações de "boa vontade" das empresas são aplicadas na prática. A necessidade desta informação poderia se tornar uma entrada para a prática da certificação de condutas e de monitoramento das mesmas. Se as empresas se convencerem das vantagens e aceitarem se 
submeter a um monitoramento permanente, isto poderia fortalecer a transparência, legitimidade e eficácia do regime trabalhista internacional.

\section{GLOBALIZAÇÃO E A DIVISÃO DO TRABALHO}

\subsection{Introdução}

O economista americano, Jeremy Rifkin, publicou um “Best seller" em 1995 chamado "Fim dos Empregos: O declínio inevitável dos níveis dos empregos e a redução da força global de trabalho" onde observava que a oferta de vagas tinha ficado aquém do crescimento da População Economicamente Ativa (PEA). A explicação para este fato decorria principalmente da evolução tecnológica e novos métodos de trabalho que permitiam produzir mais com menor participação de mão de obra e poder-se-ia projetar que em breve bastaria a ocupação de apenas $20 \%$ da PEA para manter o ritmo da economia mundial (1995).

No mesmo ano houve uma grande conferência internacional em San Francisco EUA coordenada pelo ex-dirigente da União Soviética, Mikhail Gorbachev, que reuniu vários membros da elite econômica, política e acadêmica mundial para discutir as perspectivas da chamada globalização, ainda embalados pelo fim dos regimes do socialismo real e ascensão das políticas neoliberais. Vários diagnósticos coincidiam com a avaliação de Rifkin sobre o estabelecimento de uma sociedade 20 por 80 , onde $20 \%$ da humanidade teriam empregos bons e bem remunerados com acesso ao consumo e ao lazer, enquanto $80 \%$ enfrentariam grandes problemas.

Outros comentários desdenhavam totalmente da existência de regras e direitos que pudessem "atrapalhar" os negócios como a afirmação do diretor da firma americana de 
computadores, Sun Systems, empresa criadora do "Sofware Java", que ele "empregava seu pessoal por meio de computadores, eles trabalhavam em computadores e eram demitidos por computadores" (Martin e Schumann, 1996).

Há, entretanto, outros autores mais otimistas quanto às oportunidades que podem surgir do novo paradigma produtivo como Castells, para quem a criação de novas funções devido às transformações tecnológicas suplanta as que desaparecem (1999) ou Masi (1999). Eles até reconhecem que o trabalho flexível gera um custo social, mas que esta nova divisão do trabalho também valoriza a vida social, melhora as relações familiares e introduz maior equilíbrio nas relações de gênero (Castells, 1999). Masi ainda pondera que, apesar de tudo, hoje se trabalha muito menos do que no passado e deve ser dada atenção especial a utilização do tempo livre e desenvolvimento do ócio criativo (1999).

Harvey (2004) e Dupas (1999), no entanto, chamam a atenção para a precarização das condições de trabalho em partes numerosas e importantes das cadeias produtivas globais. Dados veiculados recentemente pela OIT também apontam para esta direção ao mencionar a existência de 1,5 bilhões de trabalhadores assalariados no mundo, quase metade da PEA mundial, porém sem precisar a qualidade dos empregos deste contingente notadamente quanto ao déficit de "trabalho decente"1. Tampouco oferece maiores informações sobre a situação econômica e social da outra parcela não-assalariada da PEA mundial.

Portanto, mesmo havendo um reconhecimento de profundas transformações no mundo do trabalho, não é seguro se o prognóstico pessimista da década de 1990 mencionado no início foi cumprido. Porém, é certo que existem dados dramáticos sobre o mercado de trabalho mundial, revelados pela OIT, como a existência de centenas de

\footnotetext{
${ }^{1}$ Este conceito será tratado no Capítulo 2 da dissertação.
} 
milhões de trabalhadores discriminados por questões de gênero, raça e outros; cerca de 200 milhões de crianças trabalhando; 191 milhões de migrantes que fugiram de conflitos, desastres naturais ou da pobreza, dos quais, aproximadamente $50 \%$ são economicamente ativos; 12,3 milhões de pessoas submetidas a trabalho forçado e 2,4 milhões de pessoas traficadas anualmente, metade delas para fins de exploração sexual. Além disso, para cada 100 novos empregos gerados, 80 são informais.

Ao analisar a situação mundial dos salários, a OIT afirma que estes não acompanham o crescimento da economia há, pelo menos doze anos. Para cada $1 \%$ de crescimento do PIB entre 1995 e 2007, os salários se expandiram apenas $0,75 \%$ e nos momentos de recessão durante este mesmo período, os salários foram reduzidos em $1,55 \%$ para cada $1 \%$ de retração do PIB. Desta forma reduziu-se a participação dos salários na economia mundial no auge da globalização, o que nos aproxima da avaliação de Rifkin sobre o papel do trabalho para a movimentação da economia. (OIT, 2008).

Offe considera que o novo paradigma produtivo não gerou apenas uma crise do mercado de trabalho, mas uma crise da sociedade do trabalho, porque, embora o fluxo de bens e serviços continue crescendo, mesmo que mais lentamente, o trabalho lucrativo deixou de ser o centro das atividades vitais. Esta crise deve ser entendida como o questionamento das instituições e evidências existentes, surgimento de dificuldades inesperadas e imprevisibilidade sobre o futuro. Por exemplo, já não é possível afirmar que o crescimento econômico é condição suficiente para assegurar o pleno emprego (1984).

Há, portanto, um fio condutor entre a busca da maximização dos lucros das empresas, divisão social do trabalho inerente aos paradigmas produtivos e o custo para os trabalhadores e a sociedade em geral. A correlação de forças estabelecida em cada mudança destes paradigmas tem diferentes reflexos sobre a eficácia dos direitos trabalhistas tão 
duramente conquistadas ao longo do desenvolvimento capitalista moderno desde a primeira revolução industrial em meados do século XVIII até chegarmos a estrutura ocupacional atual que, por sua vez, começou a se conformar nos países centrais na segunda metade do século XX num processo ainda inconcluso.

\subsection{O desenvolvimento industrial e a divisão do trabalho;}

Estudos de Henri Pirenne citados por Arrighi em sua avaliação sobre a ascensão do capital afirmam que a cada estágio de desenvolvimento do capitalismo corresponde uma nova classe de capitalistas (apud Arrighi, 1996). Poderíamos acrescentar que a estes estágios também correspondem novas formas de trabalho.

Neste sentido, a primeira revolução industrial, iniciada na Inglaterra, é uma decorrência de novas formas de acumulação de capital a partir da divisão parcelada do trabalho, criação do sistema fabril, especialização dos operários e surgimento do empresário dono da indústria, bem como de mecanismos de gestão da mesma (Marglin, 2001).

A divisão parcelada do trabalho industrial se inicia com o controle e distribuição das matérias primas para os estabelecimentos artesanais, que até então caracterizavam as corporações de ofício, originárias da Idade Média, e a aquisição dos seus produtos finais para fins de comércio. Quando esta produção esparsa é organizada de modo a se realizar num mesmo local físico inicia-se a formação do sistema fabril e aos empresários - a nova classe de capitalistas - é atribuído um papel essencial neste processo, pois além de administrar o fornecimento da matéria prima e a comercialização do produto final ele passou a responder também pela expansão das instalações, melhoria dos equipamentos, 
pagamento dos salários e gestão do trabalho, esta realizada, freqüentemente, por intermédio de capatazes.

Esta mudança de paradigma ${ }^{2}$ no processo de ascensão do capitalismo foi deveras significativa na medida em que retirou do ex-artesão, o controle que este tinha sobre a produção e que passou a ser centralizado sob o domínio do empresário gerando taxas de lucro variáveis, principalmente, em função da produtividade dos operários, que, por sua vez, conformaram a nova classe produtora.

O lucro para Adam Smith era o "produto líquido" resultante da subtração da antecipação de capital feita pelo empresário para cumprir o novo papel mencionado anteriormente, do ganho da venda dos bens produzidos (Napoleoni, 2000). Para Karl Marx, além da obtenção de lucro, o empresário reproduzia seu capital por meio da expropriação da mais-valia do operário, pois uma parcela do trabalho deste compensava a antecipação de capital e o excedente de trabalho se transformava em um valor a mais, incorporado pelos empresários ao seu patrimônio. Quanto mais o operário trabalhasse e produzisse, maior seria a taxa de mais-valia e mais o capital se ampliaria, o que além de representar uma apropriação indébita, contrastava com as péssimas condições de trabalho na indústria (Marx, 2008).

Uma vez existindo demanda pelos bens a serem produzidos, o lucro poderia ser maximizado na medida em que a produção aumentasse a custos mais baixos. Uma das formas de consegui-lo seria por meio da redução de salários e aumento da jornada de trabalho, o que sem dúvida, tem sido praticado desde a primeira revolução industrial.

\footnotetext{
${ }^{2}$ Um paradigma econômico e tecnológico é um "agrupamento de inovações técnicas, organizacionais $e$ administrativas inter-relacionadas cujas vantagens devem ser descobertas não apenas em uma nova gama de produtos e sistemas, mas também e, sobretudo, na dinâmica da estrutura dos custos relativos de todos os insumos para a produção" (Freeman apud Castells, 1999).
} 
Porém, isso tem limites mais estreitos do que o aumento da "capacidade de produção" do trabalho, até porque se fosse possível trabalhar sem descanso, o dia tem somente 24 horas.

Para Adam Smith, ao analisar o caso clássico da manufatura de alfinetes, este aumento poderia ser conseguido com a especialização do operário ao reduzir progressivamente o número de operações que ele normalmente realizaria durante um processo produtivo. Se, na melhor das hipóteses o operário se especializar em uma única operação, produzirá mais e, além disso, não haverá perda de tempo durante a passagem de uma operação para outra (Napoleoni, 2000).

A coordenação das diferentes operações executadas pelo conjunto de operários foi assumida pelo empresário capitalista ou seus prepostos com a vantagem adicional de assumir o controle total da produção, pois diante deste paradigma produtivo os operários, além de não possuírem os meios de produção também perderam o conhecimento e domínio sobre o processo produtivo como um todo (Marglin, 2001).

A classe operária inicialmente formada pelos antigos mestres de ofício, ajudantes e aprendizes foi engrossada por pessoas oriundas do campo devido às transformações ocorridas na agricultura com o fim do feudalismo e da servidão no século XVIII. O desenvolvimento de máquinas ampliou a produtividade e devido à facilidade de seu manuseio possibilitou que inclusive crianças acedessem ao trabalho industrial. No entanto, as máquinas também começaram a substituir o trabalho humano gerando as primeiras situações de desemprego estrutural, pois a jornada de trabalho daqueles que continuavam empregados não se reduzia.

Para tornar o trabalho o mais produtivo possível e impor rendimento máximo ao operário, as relações de trabalho nas fábricas da primeira revolução industrial eram extremamente despóticas, influenciadas pela herança das relações hierárquicas entre os 
senhores feudais e vassalos no campo. Segundo Marx, o empresário definia as regras do trabalho ao seu bel prazer e o antigo chicote do feitor de escravos foi substituído pelo código de punições dos supervisores. Além de submeter os trabalhadores a jornadas diárias de 16 horas de trabalho, aplicava-lhes multas em caso de atrasos ou até por defeitos na matéria prima recebida para produzir. Houve casos em que os trabalhadores ficaram devendo ao patrão no final do mês. Em caso de questionamentos e oposição dos trabalhadores era comum que fossem condenados nos tribunais por rompimento de contrato (2008).

Além disso, as fábricas eram locais barulhentos, escuros e insalubres e as máquinas em geral eram perigosas, particularmente, para as crianças, causando inúmeros acidentes com mortes e mutilações. Os empresários resistiam duramente às tentativas de criação de leis que os obrigassem a adotar medidas que protegessem a integridade física dos trabalhadores na operação com máquinas perigosas. Um relatório de um inspetor da época menciona que "Certos fabricantes me falaram com leviandade imperdoável de certos acidentes - como a perda de um dedo - que consideram uma bagatela”. (Marx, 2008).

Segundo Adam Smith:

Os salários dependiam geralmente do contrato acertado entre as duas partes, cujos interesses dificilmente coincidiam. Os patrões são destinados a auferir a melhor parte, porque sendo poucos, se unem mais facilmente do que os operários que são muitos; as leis autorizam ou, pelo menos, não proíbem os patrões de se unirem em associações, o que é proibido aos operários e, finalmente, os patrões podem sustentar financeiramente um conflito trabalhista por muito mais tempo do que os trabalhadores (Smith apud Napoleoni, 2000).

A exploração atinente à revolução industrial gerou reações dos trabalhadores como revoltas e greves. Marx menciona uma greve no setor da cerâmica na Inglaterra em 1866 contra as multas impostas pelos empresários devido aos defeitos na matéria prima (2008). 
Entretanto, o movimento liderado por Ned Ludd de invasão de fábricas para destruir as máquinas às quais os operários atribuíam a responsabilidade pelo desemprego, foi inclusive anterior. O auge do "Ludismo" foi em 1812 quando ocorreu o ataque à manufatura de William Cartwright no Condado de York e a destruição de suas máquinas. Dos 64 trabalhadores posteriormente acusados pela ação, 13 foram condenados à morte e dois à deportação para as colônias. Para Hobsbawn, o "Ludismo" era "uma mera técnica do sindicalismo que precedeu a revolução industrial e as suas primeiras fases" (1982).

A resistência dos trabalhadores à exploração capitalista era contemporânea à luta social em geral pelos direitos civis, políticos e sociais. Embora eles, ao contrário dos patrões, não tivessem ainda alcançado o direito de associação, registra-se a criação de sindicatos já no início da industrialização. O sindicato dos sapateiros de Londres foi fundado em 1792 e sua abrangência já era nacional em 1804 (Hobsbawn, 1987). Os empresários resistiram o quanto puderam ao estabelecimento dos sindicatos e eles foram reconhecidos legalmente na Inglaterra apenas em 1871 e na França em 1884.

À nova divisão social do trabalho corresponde também uma divisão geográfica, pois o capital produzido pelo novo paradigma produtivo não teria como reproduzir-se estando limitado às fronteiras dos estados nacionais. A importante indústria têxtil da Inglaterra dependia da importação de matéria prima como o algodão e de mercados externos para consumir a manufatura excedente. Este país, berço da primeira revolução industrial e, por um tempo razoável, detentor do monopólio da industrialização, era também a maior potência militar da época, além de possuir a maior frota comercial. A Libra Esterlina tornou-se o padrão monetário internacional e referência para as operações comerciais. A partir desta situação o país assumiu uma posição hegemônica na economia e política mundial, pelo menos até 1914 (Pochmann, 2001). 
O modelo de desenvolvimento que estabeleceu foi o de importar produtos primários para alimentar sua indústria, além de alimentos para consumo interno, altamente compensado pela exportação de bens industrializados. Por isso, era um árduo defensor do livre comércio e do fim da escravidão para ampliar suas exportações. Os investimentos que realizava no exterior eram basicamente em infra-estruturas locais como ferrovias e portos ou processadores de alimentos, como os frigoríficos, que facilitassem o fluxo de produtos primários em direção à Inglaterra.

Assim, já em 1900, apenas 9\% da força de trabalho inglesa atuavam no seu setor primário (agricultura e mineração) enquanto a PEA no campo da Alemanha era 34\%, nos EUA 37\%, França 43\%, Itália 59\%, Espanha 67\%, Japão 69\%, México 71\%, Índia 72\%, Brasil 73\%, Rússia 77\% e China 81\% (Morris \& Irwin apud Pochmann, 2001).

Alguns países começaram a romper o monopólio industrial da Inglaterra na segunda metade do século XIX como os EUA, França e Alemanha, principalmente, contrariando o preceito liberal das "vantagens comparativas"3 defendido por David Ricardo, outro economista inglês ao adotarem políticas de estado de proteção à indústria infante por meio de altas tarifas externas. No entanto, mesmo assim, a relação importação de commodities e exportação de bens industrializados, e conseqüentemente a divisão internacional do trabalho, perdurou por muito tempo entre a Inglaterra e suas colônias asiáticas, africanas e caribenhas, bem como com os países latino-americanos que alcançaram sua independência política da Espanha e Portugal no século XIX. As relações comerciais com países soberanos como a China e Japão foram estabelecidas por meios militares.

\footnotetext{
${ }^{3}$ Grosso modo é um conceito que defende haver maior vantagem econômica para os Estados Nacionais se eles apenas exportarem bens cuja produção é favorecida pelas suas vantagens naturais como clima, existência de matéria prima, energia barata, etc e importarem o que é produzido com maiores vantagens em outros países. Desta forma, os custos cairiam, o comércio mundial cresceria e todos os países ganhariam. Assim, a Alemanha deveria priorizar a exportação de trigo, Portugal ao vinho e a Inglaterra à manufatura.
} 
O que mudou neste aspecto no final do século XIX foi a entrada de novos atores imperialistas na disputa pelos mercados coloniais como a França, Alemanha, Itália, EUA e outros de menor peso. De todo modo, o emprego nos países da periferia era essencialmente agrícola, enquanto nos países centrais era em grande proporção industrial.

Por mais impactante que fosse a primeira revolução industrial, ela ainda era limitada do ponto de vista tecnológico às máquinas movidas a vapor, embora estas permitissem a mecanização de lanifícios, teares, fundições, cerâmicas e outros. Já a segunda revolução iniciada em meados do século XIX introduziu novas tecnologias e fontes de energia como a utilização dos recursos da eletricidade, do motor de combustão interna, produtos químicos, siderurgias de grande porte, telégrafo, entre outros (Castells, 1999).

Essas inovações permitiram ampliar a escala da produção industrial e as perspectivas de crescimento de empreendimentos e capital. O centro de gravidade da industrialização passou a ser compartilhada entre Inglaterra, Estados Unidos e Alemanha, embora a lógica da divisão internacional de trabalho geográfica entre países exportadores de bens industriais e exportadores de bens primários permanecesse praticamente inalterada até o final da segunda guerra mundial.

A classe operária cresceu, surgiram mais vagas para funções com maior capacitação técnica nas áreas de engenharia, física, química e outras, mas uma alteração relevante do modo de produção somente viria a ocorrer no início do século XX com aplicação do “Taylorismo" e do "Fordismo".

O americano Frederick Taylor elaborou seus "Princípios de administração científica" partindo da constatação de que a capacidade produtiva de um trabalhador era sempre superior a sua produção real. Por mais que aumentasse sua especialização e destreza e, conseqüentemente, sua produtividade, esta nunca chegava à possibilidade real devido a 
troca de operações e de ferramentas, bem como de deslocamentos dentro do espaço de produção. Além disso, os trabalhadores desenvolviam suas maneiras particulares de trabalhar e preservar técnicas como meio de se tornarem insubstituíveis na empresa pelo temor de demissão diante da constante eliminação de postos de trabalho com a introdução de novas máquinas. Taylor acreditava que o aumento da produtividade ampliaria os lucros dos empresários, bem como seus investimentos em novas atividades produtivas e assim novos empregos e fontes de renda seriam gerados. Portanto, alcançar uma produtividade maior seria do interesse de todos e os trabalhadores estariam equivocados ao se comportar da forma mencionada (Pinto, 2007).

Para resolver essa situação era necessário subdividir as diferentes atividades em tarefas simples, assim como os movimentos para realizá-los e medi-los para se conhecer o tempo real para sua execução. Desta forma, os administradores de qualquer empresa teriam como exigir a quantidade ideal de trabalho de seus empregados, sem prejudicar sua saúde pelo excesso e nem pagando pelo que não era realizado. Além disso, assim também se separariam as funções dos administradores das dos operários. Os primeiros determinariam as técnicas e a engenharia da produção e os operários executariam estas determinações para as quais poderiam, inclusive, ser treinados se fosse necessário (Pinto, 2007).

Novamente, como ocorreu no exemplo da produção de alfinetes de Smith, o empresário buscou o máximo de produtividade sem desperdícios e o que o trabalhador sentia e pensava sobre isto, não lhe importava. Os bons resultados gerados pelas técnicas tayloristas, seu suposto cientificismo e isenção ideológica, inclusive contribuiu para a produção industrial soviética após a Revolução de 1917 também adotar seus conceitos.

Algumas das idéias de Taylor foram incorporadas na organização da produção que Henry Ford idealizou, mas seu mérito principal foi a introdução da padronização e 
massificação da produção em alta escala de bens com conteúdos mais complexos, pois já existia a produção em série de parafusos, panelas, trilhos e outros. A massificação reduziria os custos e os produtos finais se tornariam mais baratos e acessíveis ao maior número possível de consumidores. Embora o valor individual de cada bem caísse, o conjunto de vendas representava lucros enormes.

A combinação da produção contínua por meio de linhas ou esteiras de produção combinadas com montagens através de movimentos simples e repetitivos permitiu gerar este aumento, bem como sua padronização. Ford aplicou esta nova forma de produção na fabricação de automóveis e sua empresa tornou-se uma das maiores do mundo nesse setor.

Esta nova divisão do trabalho, embora extremamente alienante, era de execução tão simples que muitos imigrantes nos EUA, mesmo sem falar inglês conseguiam emprego na indústria automobilística. Quanto à alienação a posição de Henry Ford era a seguinte:

Necessariamente o trabalho de muitos homens tem de ser pura repetição de movimentos, pois de outro modo não se pode conseguir sem fadiga a rapidez da manufatura que faz descer os preços e possibilita os altos salários. Algumas das nossas operações são excessivamente monótonas, mas também são monótonos muitos cérebros; inúmeros homens querem ganhar a vida sem ter que pensar - e para estes a tarefa unicamente de músculo é a boa. Possuímos em abundância tarefas que exigem cérebro ativo, e os homens que no trabalho de repetição se revelam de mentalidade ativa não permanecem nele muito tempo (Ford apud Pinto, 2007).

É sugerido nesse posicionamento e se tornou uma crença geral que os salários pagos pela FORD eram de monta a permitir que os operários adquirissem o bem que produziam. Isto, no entanto, não fazia parte das preocupações originais de Henry Ford e foi na verdade resultado das lutas sindicais da década de 1920 ao conquistarem para os trabalhadores a incorporação de uma parte dos ganhos de produtividade em forma de aumentos salariais. Como a posição acima ilustra, Ford tinha pouco apreço pelos que aceitavam trabalhar de 
acordo com o seu método e ele chegou a empregar mais de mil funcionários para monitorar o comportamento do conjunto de empregados. O legendário dirigente sindical americano, presidente da United Auto Workers of America (UAW), Walther Reuther, sofreu um atentado a bala durante um piquete na frente da FORD em Detroit (Lichtenstein, 1995).

Foi durante a segunda revolução industrial que surgiram avanços quanto aos direitos políticos e sociais dos trabalhadores como jornada máxima de trabalho; proteção à saúde, à velhice e contra o desemprego. O primeiro país a adotar alguns deles foi a Alemanha no final do século XIX, governada por Bismarck e que tomou esta iniciativa para tentar neutralizar a crescente influência dos sindicatos e do Partido Social Democrata. Entretanto, a maioria destes direitos só viria a se consolidar após a segunda guerra mundial, embora nas décadas anteriores já houvesse experiências de participação de Partidos Socialistas em governos, bem como a constitucionalização de direitos sociais e trabalhistas em alguns países.

O auge do "Fordismo" foi no período após a segunda guerra mundial e representou a solução para o "boom" de acumulação que surgiria então com os enormes fluxos de capital para reconstruir a Europa e o Japão, a redução de barreiras ao comércio e investimentos, a descolonização e ingresso de novas nações na economia mundial e a política desenvolvimentista de substituição de importações implementada por uma série de países que tentavam romper com a dependência da primeira divisão geográfica do trabalho, como a Coréia do Sul, Brasil, Argentina, México e outros (Harvey, 2004).

Este momento e o que se seguiu até meados da década de 1970 apresentaram também uma nova divisão geográfica do trabalho com a inclusão de mais países industrializados e em vias de industrialização no cenário mundial. Os trabalhadores na agricultura migravam em número cada vez maior para as cidades em busca de empregos nas fábricas e se 
formaram os primeiros contingentes de mão de obra excedente que comporiam posteriormente o mercado informal de trabalho. Os trabalhadores na indústria representavam o setor social hegemônico e os do setor de serviços começaram a ascender ligeiramente.

O pensamento econômico liberal estava em defensiva após o término da segunda guerra mundial, exatamente porque a competição liberal e imperialista durante o final do século XIX e início do seguinte provocou a I Guerra Mundial, assim como a superprodução sem barreiras que gerou a crise de 1929 e a depressão econômica que se seguiu. A Segunda Guerra Mundial estava relacionada ao término mal resolvido da Primeira, particularmente, devido a imposição de pesadas indenizações a Alemanha, o que contribuiu para a ascensão do nazismo e reinício do conflito onde milhões perderam a vida.

O "Fordismo" coabitou perfeitamente com a visão "keynesiana"4 de intervenção do Estado na economia, adotada principalmente pelos governos social-democratas; com o marco regulatório internacional definido nos Acordos de Bretton Woods ${ }^{5}$; com o pleno emprego, com a ação sindical e alargamento dos direitos sociais. A articulação tripartite entre capital, Estado e trabalho foi a base fundamental para a evolução do modelo.

O auge do "Fordismo" entre o término da segunda guerra mundial e meados da década de 1970, ficou conhecido como os "30 anos de ouro do capitalismo". Apesar dessa denominação é necessário ressaltar que a prosperidade e o "Welfare state" correspondente se limitaram a menos de 20 países centrais situados no norte da Europa e da América, além

\footnotetext{
${ }^{4}$ John Maynard Keynes foi um economista inglês que desenvolveu uma teoria econômica alternativa ao liberalismo com papel regulador do Estado na economia para enfrentar os momentos de crise e para promover o desenvolvimento. Foi adotada pela maioria dos países capitalistas após a Segunda Guerra Mundial.

${ }^{5}$ É o nome é o do lugar onde foi definida a nova política monetária internacional e o padrão - ouro para referência do câmbio, bem como a política para reconstrução européia e as instituições que as executariam, respectivamente, Fundo Monetário Internacional (FMI) e Banco Mundial (Bird). Os principais mentores de sua constituição foram Keynes e o economista americano Dexter White.
} 
do Japão e Austrália. Estes países detinham aproximadamente $25 \%$ da população e $75 \%$ da economia mundial.

Mesmo entre eles havia diferenças quanto ao desenvolvimento econômico, alto e médio, por exemplo, comparando Estados Unidos e Canadá, e internamente também havia diferenças regionais como, por exemplo, o industrializado e rico norte da Itália em comparação com o sul do país, predominantemente agrícola, pobre e com taxas de desemprego que chegavam a $30 \%$.

Em alguns países fora desse grupo desenvolvia-se um "Fordismo periférico" como no Brasil, México, Argentina, Coréia do Sul, Malásia, África do Sul, entre outros, normalmente estimulado pelos respectivos Estados e que alcançaram resultados interessantes. Por exemplo, metade das exportações brasileiras no início dos anos 1970 era composta por bens manufaturados.

No entanto, o "Fordismo" nestes "Países de Industrialização Recente" (NICs na sigla em inglês) não favoreceu aos trabalhadores se beneficiarem dos ganhos de produtividade e tampouco desenvolver políticas sociais abrangentes como nos países centrais, pois na maioria dos NICs a economia se desenvolveu sob governos extremamente autoritários com sérias restrições à atuação sindical e política da classe trabalhadora (Munck, 2002).

Este período de prosperidade começou a apresentar sinais de debilidade nos anos 1960 e a recessão mundial de 1973, a primeira que ocorreu depois da guerra marca a sua crise, embora não se possa atribuir o fim dos "anos dourados" a uma única razão e sim a várias delas, como nos demais períodos históricos de expansão e contração do capitalismo.

Em primeiro lugar, a aceleração da competitividade entre as corporações transnacionais e a busca de liberalização financeira já não comportava a produção limitada 
às fronteiras dos Estados Nacionais, uma das características da divisão internacional do trabalho do período fordista.

Entre 1973 e 1974, quando a recessão atingiu seu ápice, os países exportadores de petróleo promoveram uma série de aumentos no seu preço e como registrou Hobsbawn "um dos motivos pelos quais a Era de Ouro foi de ouro é que o preço do barril de petróleo saudita custava em média menos de dois dólares durante todo o período de 1950 a 1973 ...” (1994). Isto, seguramente, também contribuiu para mudanças no paradigma produtivo.

Porém, o marco mais concreto da crise foi o rompimento dos "Acordos de Bretton Woods" quando os EUA abandonaram a paridade entre o dólar e o "padrão ouro" que geravam as referências, monetária e cambial, na época. Esta paridade, que durou quase trinta anos, inicialmente, oferecia a liquidez necessária para expansão mundial de investimentos americanos, pois os EUA tinham reservas de ouro suficientes devido ao peso de sua economia para imprimir mais moeda quando precisassem. Porém, quando a guerra do Vietnã, o programa espacial e outras despesas internas começaram a gerar déficit público, as reservas se erodiram e os EUA começaram a exportar sua inflação para o resto do mundo.

Paralelamente ao déficit público, os Estados Unidos começaram também a enfrentar um forte desequilíbrio da balança comercial devido à agressividade das exportações alemães e japonesas em direção ao mercado interno norte americano. Como o dólar era a referência monetária mundial, não tinham como desvalorizá-lo para se proteger da competitividade comercial externa.

Numa tacada unilateral, o governo americano provocou uma série de medidas macro econômicas em nível mundial em seu próprio benefício como, por exemplo, a atração de investimentos para os EUA. Apesar da instabilidade inicial que a iniciativa causou, foi um 
passo importante na direção da liberalização financeira em nível mundial que, entre outros fatores, tornou-se um atrativo para a realização de altos lucros por meio da especulação, inclusive desviando recursos originalmente destinados à produção para a aplicação em derivativos financeiros.

Além do câmbio flutuante e da liberalização financeira, a introdução de novas tecnologias e novos métodos de trabalho na indústria também contribuiu para gerar o novo paradigma de acumulação capitalista em substituição ao "Fordismo".

Esta substituição havia se iniciado até antes do fim do "Sistema de Bretton Woods" pela paulatina introdução de novas tecnologias nas linhas de produção. A automação de máquinas como as prensas, por exemplo, se fez presente na indústria automobilística americana ainda no início dos anos 1950 (Dofny, 1968).

Outro fator que permitiu a mudança de paradigma sem maiores resistências foi a desmistificação que a prosperidade e o "Welfare state" conviveriam com boas condições de trabalho oportunidades de ascensão profissional, inclusive gerando demandas educacionais devido a crescente inovação tecnológica na produção.

Embora os locais de trabalho, principalmente nas grandes empresas, não fossem iguais aos dos insalubres estabelecimentos do início da revolução industrial, mencionados por Marx, ainda assim o sistema de produção comportava uma maioria de trabalhadores pouco qualificados, muito especializados nas suas atividades e sob severa supervisão e uma minoria qualificada que planejava, projetava e supervisionava a produção.

A insatisfação dos trabalhadores quanto ao ritmo da produção e em relação ao trabalho repetitivo e alienante, inclusive nas atividades administrativas das fábricas e escritórios, era grande. $\mathrm{O}$ acesso a empregos mais qualificados era "uma realidade para poucos" (Braverman, 1981).

Já nos anos 1960, as gerações mais jovens de trabalhadores na indústria dos países desenvolvidos começaram a se opor à alienação do modo "Fordista" de produção e ao despotismo das fábricas por meio de sabotagens, absenteísmo, acidentes, provocação de defeitos de fabricação, "turn-over", etc, em paralelo às agitações estudantis e outros movimentos sociais que questionavam uma série de normas e costumes correntes (Gorz, 
2001). Braverman acrescentou que, além destas atitudes, a insatisfação também provocava o uso de drogas, alcoolismo, agressividade e delinquiência (1981).

Outro meio para expressar a rebeldia era por meio de greves selvagens, freqüentemente, à revelia dos sindicatos. Mesmo depois de um século de lutas para serem formalmente reconhecidos pelo Estado e empresários para representar os trabalhadores na definição das relações industriais, na opinião dos trabalhadores mais jovens eles já estavam domados, burocratizados e incorporados ao sistema capitalista. Por exemplo, nos países centrais no final dos anos 1960 e início dos 1970, as greves no Canadá somente perdiam em número para os da Itália (Heron, 1996).

O filósofo alemão, Herbert Marcusse, num de seus livros, "A ideologia da sociedade industrial", desenvolveu uma forte crítica à sociedade de consumo e a submissão da classe trabalhadora à industrialização para disponibilizar os bens consumíveis em quantidades cada vez maiores. Esta análise teve muita relevância na fundamentação política dos protestos estudantis dos anos 1960 (1967).

A somatória dos insumos novas tecnologias, resistência dos trabalhadores ao modo de produção, retorno da concepção liberal de economia em substituição ao "keynesianismo" e, principalmente, a crise da acumulação capitalista, favoreceu novamente a ocorrência de uma reestruturação produtiva, porém desta vez mais profunda e de acordo com os interesses de uma nova "classe de capitalistas" extremamente fortalecida e representada pelas grandes corporações multinacionais. Esta reestruturação seria baseada na idéia de uma “acumulação flexível”, caracterizada pela mudança tecnológica, pela automação, pela descentralização da produção (com a conseqüente dispersão geográfica para zonas de controle do trabalho mais fácil), pela especialização na produção e nos nichos de mercado, e finalmente, pelas fusões e medidas para acelerar o tempo de giro do capital

Contudo, antes de aprofundar essas características e seus efeitos sobre o mundo do trabalho, será comentado brevemente o contexto em que ocorrem como a globalização da economia, ascensão das políticas neoliberais e o papel das empresas multinacionais. 


\subsection{A globalização e a atuação das empresas multinacionais;}

A tendência histórica no sistema internacional a partir da primeira revolução industrial até a Grande Depressão do final da década de 1920 era de aumento nas interações comerciais entre o conjunto de países existentes, embora com uma interrupção durante a Primeira Guerra Mundial. Quando esta crise se iniciou em 1929 houve uma retração da tendência e as políticas comerciais nacionais assumiram altos índices de protecionismo.

Ao final da década de 1940 e superada a Segunda Guerra Mundial iniciou-se um período de gradual liberalização comercial por meio de sucessivas Rodadas de Negociações no âmbito do GATT ${ }^{6}$. Estas foram impulsionadas pelos governos dos países industrializados conforme o preparo de suas empresas multinacionais para competir no mercado internacional e desde então elas jogam um papel decisivo para a atual integração da economia capitalista.

Até a década de 1980 esta integração ocorreu basicamente através do comércio mundial entre os países industrializados e os temas de interesse dos países em desenvolvimento raramente eram considerados. Quando estes eventualmente se beneficiavam dos acordos, era como "carona". Por exemplo, em dois setores onde os países menos desenvolvidos poderiam se tornar competitivos no mercado mundial, têxteis e produtos agrícolas, a liberalização da primeira foi "congelada" por quase 40 anos e a segunda nunca ocorreu.

No entanto, o "lobby" das grandes empresas multinacionais sobre seus governos tinha efeitos opostos. A pressão de empresas como a "American Express" e "Citicorp", interessadas em expandir o mercado de cartões de crédito internacionalmente, e da "Merck" e "Phizer" que queriam fortalecer os mecanismos de proteção de suas patentes de produtos farmacêuticos em nível mundial, sobre o governo dos EUA levou-o a propor o início de uma nova rodada de negociações comerciais no início da década de 1980. Esta, a Rodada Uruguai do GATT, iniciou-se em 1986 e incluiu, entre outros temas na agenda, a liberalização do comércio de serviços e regras de propriedade intelectual, apesar de o segundo tema não ter relação direta com o comércio.

\footnotetext{
${ }^{6}$ O GATT foi fundado em 1948 tendo sido originalmente concebido como uma Organização Internacional de
} Comércio (OIC) para funcionar em cooperação com as demais instituições de Bretton Woods (FMI e BIRD). 
Após a Segunda Guerra Mundial, o comércio mundial cresceu anualmente mais do que as economias nacionais e atualmente várias Empresas Multinacionais (EMN) possuem um patrimônio superior ao Produto Interno Bruto (PIB) de muitos Estados Nacionais. Por sua vez, o estoque de investimento externo direto (IED) destas empresas superou o volume monetário do comércio internacional a partir da década de 1980, embora não de forma linear e dois terços do comércio mundial e do volume de IED passaram a ser realizados pelas EMNs a partir deste momento, sendo que um terço era aplicado em transações entre elas mesmas ou entre - firmas, termo como se tornou conhecido.

Porém, ao contrário da situação mencionada anteriormente quando o investimento direto das EMN's era dirigido aos países periféricos para facilitar a exportação de produtos primários e alimentos para os países centrais ou auferir grandes lucros com a exploração de serviços públicos, particularmente energia e transporte; em meados do século $\mathrm{XX}$ as empresas multinacionais começaram a instalar unidades de produção de bens duráveis em países como Brasil, Argentina, México, Malásia, Cingapura, entre outros.

Para demonstrar esse poderio em valores concretos temos que a média anual de IED das EMN's entre 1982 e 1986 era US\$ 61 bilhões, mas em 1996 o estoque ascendeu a US\$ 359 bilhões, em 1999 a US\$ 865 bilhões e em 2007 a US\$ 1,83 trilhão (Unctad, 2008).

A principal fonte desse investimento direto são empresas multinacionais dos países industrializados. Em 2007 responderam por quase três quartos do total de investimentos (US\$ 1, 25 trilhão) sendo que 80\% deste valor provinham da "Tríade" (EUA, União Européia e Japão). Estes são também os países que hoje controlam a maior parte do comércio mundial e é onde ficam as sedes de 91 dos 100 maiores oligopólios internacionais.

O número de empresas multinacionais também se expandiu extraordinariamente. Em 1969 existia em torno de 7.000 delas. Em 1996 o seu número se ampliou para aproximadamente 44.000 com 280.000 subsidiárias espalhadas pelo mundo e em 2007 havia 79.000 com 790.000 subsidiárias. (Unctad, 2008).

Essa quantidade de empresas e subsidiárias demonstra a interdependência existente atualmente entre as economias capitalistas por meio da agilidade e quase instantaneidade de transações comerciais e deslocamento de capitais resultantes de avanços tecnológicos dos meios de comunicação, informação e transporte com particularidades e dimensões nunca 
vivenciadas antes. O fluxo de informações ocorre 24 horas por dia. Certas empresas aproveitam-se, inclusive, dos diferentes fusos horários como os bancos, por exemplo, para enviarem dados para serem digitados em países asiáticos no final do dia, devido aos salários menores de digitadores naquela região do que nos seus próprios países, e receberem o produto acabado de volta na manhã seguinte.

No tocante ao fluxo de informações e à comunicação a novidade não está na velocidade, mas sim no barateamento de seus custos. A redução dos custos de comunicação permitiu a intensificação e massificação de seu uso, enquanto o aumento da velocidade pode ser entendido como consequiência de uma demanda, e não como causa desta (Keohane e Nye, 2000).

Esse processo foi denominado globalização econômica ou mundialização da economia conforme a preferência de Chesnais por entender que este termo corresponde melhor "à capacidade estratégica de todo grande grupo oligopolista, voltado para a produção manufatureira ou para as principais atividades de serviços de adotar, por conta própria, um enfoque e conduta 'globais'”' (1996).

Portanto, a globalização no campo econômico pode ser resumida basicamente a dois processos interligados: a globalização financeira e a atuação das grandes corporações multinacionais dentro de uma lógica transnacional.

A primeira surge a partir de uma série de medidas adotadas pelos países desenvolvidos para propiciar um cenário adequado para a retomada das taxas de lucratividade das grandes corporações multinacionais, para o desenvolvimento de novos instrumentos financeiros no mercado internacional e para a generalização das operações de securitização.

A liberalização financeira proporcionada pelo fim do "Sistema de Bretton Woods" possibilitou que o fluxo de capitais nas bolsas de valores, rapidamente, se tornasse maior que os investimentos na produção. O desenvolvimento da computação permitiu que "as operações bancárias se tornassem cada vez mais indiferentes aos limites de tempo, lugar e dinheiro”. "[...] um norte americano pode operar sua conta bancária de New York através de uma 'caixa eletrônica' instalada em Hong Kong [...]”' (Harvey, 2004).

O outro lado da globalização representa a atuação das empresas multinacionais que segundo Chesnais: “como os 'mercados financeiros' [...] erguem-se hoje como força 
independente todo-poderosa perante os Estados, [...] perante as empresas de menores dimensões e perante as classes e grupos sociais despossuídos, que arcam com o peso das 'exigências dos mercados' (financeiros)" (1996).

As empresas concentraram poder financeiro, produtivo e tecnológico de modo a, mesmo mantendo um centro num único país, desenvolverem cada vez mais a produção em escala global, além de extrair vantagens dos diferentes fatores de produção entre países, inclusive suas políticas governamentais. Elas constituíram cadeias produtivas globais ou redes que envolvem inclusive a participação de pequenas e médias empresas (Dupas, 1999).

No entanto, as mudanças impulsionadas pela globalização não se desenvolvem da mesma forma e com a mesma intensidade por toda parte. Neste sentido, a nova ordem internacional que ela marca gerou implicações assimétricas para os países, para diferentes grupos sociais e suas organizações representativas.

Harvey discute os efeitos da globalização para além do seu aspecto econômico defendendo que "há uma relação entre formas culturais pós - modernas e o surgimento de modos mais flexíveis de acumulação do capital e um novo 'giro' na 'compressão espaço temporal' da organização do capitalismo" (2004). Porém, apesar desta contribuição para a análise mais ampla do novo paradigma produtivo e seus impactos para a sociedade mundial, nos ateremos aos aspectos econômicos, políticos e sociais da globalização.

\subsection{A divisão do trabalho na era da globalização;}

A introdução da automação e robótica substituindo operários na linha de montagem e a insuficiência do "fordismo" para assegurar o crescimento da produtividade levou a experiências de novas formas de produção combinando o modelo anterior de linhas de montagem com formas flexíveis de produção (Harvey, 2004).

O novo sistema produtivo desenvolvido inicialmente no Japão e denominado "Toyotismo" permitiria que se ampliasse a produção com um número menor de trabalhadores. Ele é caracterizado pelo sistema "just in time" que permite programar a produção de modo a não gerar estoques, nem de matéria prima e nem de produtos finais, bem como utilizar integralmente a disponibilidade de máquinas e mão de obra. Este sistema requer flexibilidade nos contratos de mão de obra e também a descentralização da produção, inclusive geográfica, por intermédio de "outsourcing" (terceirização). Desta 
forma a empresa dona do bem a ser produzido, bem como de sua marca, apenas administra a sua produção e se apropria dos ganhos dela. Eventuais riscos e prejuízos do sistema são jogados sobre os ombros dos trabalhadores e das empresas subcontratadas.

Por exemplo, em 1990, a multinacional italiana Benetton, possuía um centro nevrálgico que incluía a direção central da empresa, criação e marketing, logística e informática e o controle da qualidade do corte, das cores e do produto acabado. Neste núcleo não trabalhavam mais de mil pessoas ao todo. No entanto, a partir deste centro controlava-se uma rede de vendas a varejo composta por 4.500 lojas franqueadas em 52 países que empregavam cerca de 40.000 pessoas e também uma rede de produção descentralizada de 450 empresas subcontratadas que empregavam aproximadamente 24.000 pessoas (Chesnais, 1996).

Desta forma, a Benetton e outras empresas multinacionais que adotam esquemas semelhantes, têm como negociar contratos extremamente vantajosos e isentos de riscos, pois estes ficam com as empresas subcontratadas e com as lojas franqueadas. Da mesma forma quanto às relações de trabalho, a Benetton só se responsabiliza pelos empregados no seu núcleo central e não nas redes. Ou seja, a probabilidade é que neste caso os mil trabalhadores empregados diretamente pela empresa tenham um contrato regular de trabalho com bons salários e benefícios, enquanto os 64.000 que trabalham na produção e nas vendas provavelmente são submetidos a contratos precários e mal pagos.

Para Dupas, não há um padrão espacial de distribuição da terceirização muito definida. A escolha da localização depende dos fatores de produção e custos relativos que se buscam. No caso dos segmentos produtivos que utilizam mão de obra mais intensiva e menos qualificada, escolhem-se os países, em geral na periferia, onde ela é farta e barata (1999).

Outro exemplo clássico é o da NIKE que subcontratou $100 \%$ de sua produção e fragmentou-a por muitos países. A sua produção inicialmente limitada aos EUA, Inglaterra e Japão foi paulatinamente transferida a países como Indonésia, Malásia, Filipinas, China, entre outros, utilizando-se inclusive de trabalho informal por meio de sub-fornecedores domésticos (Dupas, 1999). 
Mesmo setores produtivos mais complexos como a indústria automobilística fragmentaram-se mundialmente em diversos níveis entre os principais mercados consumidores, empresas montadoras e fornecedoras de autopeças.

Ainda assim, apesar da fragmentação e constituição das redes de produtivas globais, dois terços dos empregos gerados pelas EMN's localizam-se nos países de origem delas e um terço nos países em desenvolvimento, porém, estes são normalmente de baixa qualificação.

Alguns países de desenvolvimento mais tardio, como, por exemplo, o Brasil, Argentina e México na América Latina e Taiwan, Cingapura, Hong-Kong, Malásia e Coréia do Sul no continente asiático adotaram políticas de substituição de importações a partir da década de 1950 que lhes permitiu também competir no mercado mundial com suas vantagens comparativas, entre elas, o baixo custo de sua mão de obra.

Esse modelo tinha uma participação importante do Estado e contava também com a presença de empresas multinacionais em vários setores da indústria. Suas economias eram mais fechadas que as dos países centrais e não possuíam o mesmo nível de proteção social. Apesar da crise que a mudança de paradigma caracterizou nesses países, particularmente, devido à crise da dívida externa, algumas empresas multinacionais importantes atualmente têm origem nesses países.

Embora a descentralização da produção tenha gerado empregos, mesmo sendo de baixa qualidade, na periferia, eles representavam apenas em torno de $2 \%$ da PEA nesses países, o padrão usual da implantação do novo modelo produtivo foi o aumento do desemprego.

Este se tornou crônico na Europa a partir da segunda metade dos anos 1970 até o final da década de 1990, mantendo-se freqüentemente em patamares superiores a 10\%. Nos EUA, era menor, porém em 1997, 18,4\% da PEA americana trabalhavam em tempo parcial, o que equivalia a 21 milhões de pessoas e ao mesmo tempo, o número de trabalhadores temporários saltou de 640 mil em 1987 para mais de três milhões em 1999 (Pochman \& Borges, 2002). Em 1999 havia um total de 84 milhões de desempregados ou subempregados na América Latina e o desemprego chegou a 11\% em 2002 e 10\% em 2004. (Barbosa; Jakobsen; Barbosa, 2005). 
A subcontratação decorrente do novo modelo estimulou o crescimento do trabalho informal entendido como atividades de baixa qualificação, por conta própria ou produção familiar, em pequenos estabelecimentos, com pouca tecnologia, sem acesso á crédito e freqüentemente de curta duração ou ainda por meio de cooperativas de mão de obra.

Durante a política de substituição de importações nos países em desenvolvimento, o trabalho informal era uma consequiência do excedente de mão de obra que provinha das zonas agrícolas para as regiões urbanas e que a nova indústria não conseguia absorver. Porém, no período neoliberal tornou-se também uma alternativa ao desemprego e parte do novo paradigma, tendo em vista que na conformação das cadeias produtivas globais a utilização do trabalho informal tornou-se um fator de aumento de competitividade. O quadro abaixo mostra sua evolução mundial.

Tabela 1. Participação do trabalho informal no emprego urbano (\%)

\begin{tabular}{|c|c|c|c|c|c|}
\hline Período & Mundo & $\begin{array}{c}\text { Países } \\
\text { Desenvolvidos }\end{array}$ & África & $\begin{array}{c}\text { América } \\
\text { Latina }\end{array}$ & Ásia \\
\hline $1980-1989$ & 26,0 & 13,0 & 44,0 & 29,0 & 26,0 \\
\hline $1990-2000$ & 32,0 & 12,0 & 48,0 & 44,0 & 32,0 \\
\hline
\end{tabular}

Fonte: OIT apud Barbosa, Jakobsen e Barbosa, 2005.

Aumentou também a presença de mulheres no mercado de trabalho em função de mudanças culturais e redução da renda familiar. Em muitos países, a força de trabalho feminina chegou a 40\% (Harvey, 2004: 178).

É grande sua presença na informalidade. Por exemplo, no sistema de trabalho a domicílio do setor de vestuário e calçados, predominam as mulheres. Uma pesquisa realizada pela CUT em 1999 sobre o perfil do trabalho informal na cidade de São Paulo mostrou que as mulheres, os não brancos, os jovens até 25 anos, as pessoas com mais de 40 anos e as com baixa escolaridade tinham maior probabilidade de não conseguir um contrato regular de trabalho. A combinação de dois ou mais destes fatores ampliava esta tendência (Jakobsen; Martins; Dombrowski, 2000).

A acumulação flexível também pressupõe a flexibilização de direitos trabalhistas, inclusive nos países industrializados. As altas taxas de desemprego e ausência de 
estratégias eficazes dos sindicatos para lidar com a mudança de paradigma e seus efeitos sobre o mundo do trabalho muitas vezes os têm levado a negociar novos contratos de trabalho com várias concessões em relação aos direitos tradicionais.

Em outros casos, a produção é planejada para não conceder direitos, além do pagamento de salários, por sua vez, de baixo valor. É o caso do México com suas "maquillas" instaladas na fronteira com os EUA. Graças à tarifa zero do Nafta, as indústrias americanas mandam peças de vestuário, eletrônicos e outros, para serem montadas nestas instalações mexicanas, a custos extremamente baratos e em seguida os bens já montados retornam aos EUA para serem vendidos com bons lucros.

Para garantir estes baixos custos, ignoram-se as leis trabalhistas e ambientais nacionais, muitas vezes simplesmente demitindo todos os trabalhadores em caso de resistência ao sistema. As "maquillas" empregam hoje, aproximadamente, um milhão de pessoas, a maioria mulheres e jovens; não desenvolvem tecnologia e encerram suas atividades com a mesma rapidez que as abrem e geralmente sem pagar indenizações para ninguém. Tampouco agregam valor à sua produção, pois exportam praticamente o mesmo valor daquilo que importam de matéria prima. (Harvey, 2004).

Este exemplo, muito relacionado com a proximidade da fronteira com os EUA, espalhou-se pelo mundo e as suas formas de funcionamento, bem como seu marketing, em vários lugares tornaram-se políticas de Estado. A maioria dos governos da América Central começou a criar "Zonas de Processamento de Exportações" (ZPE) ou "Zonas Francas", onde as empresas podem se instalar gratuitamente e isentas do pagamento de impostos. Os governos de Honduras, República Dominicana, El Salvador e outros começaram a divulgar as vantagens destas zonas argumentando a proximidade dos EUA, a isenção de impostos, estrutura gratuita e pronta para começar a produzir e salários de US\$ 0.50 à hora $(\mathrm{R} \$ 1,10)$. As ZPEs começaram a se instalar também na Ásia e no caso de Bangladesh, além de prometer salários ainda menores, o governo assegurava que os sindicatos estavam proibidos por lei de atuar nestas áreas.

Esse novo quadro estrutural que combinou desemprego com informalidade e redução de direitos básicos concentrou a renda e ampliou a pobreza, bem como reduziu significativamente a capacidade de resposta dos sindicatos diante das novas condições de trabalho que as empresas começaram a exigir em nível internacional e que resultaram em 
trabalho precário proporcionado pela competitividade entre mão de obra cada vez mais barata de um país para outro.

\subsection{O paradigma neoliberal: Estado Mínimo e redução de direitos}

Após a Segunda guerra Mundial ocorreu uma reestruturação do Estado e das relações internacionais nos países desenvolvidos de modo a evitar o retorno das condições catastróficas que ameaçaram a ordem capitalista durante a profunda recessão dos anos 1930 e das rivalidades geopolíticas que provocaram esta guerra. Fortaleceu-se a concepção quanto à necessidade de um pacto político que envolvesse Estado, capital e trabalho para assegurar desenvolvimento econômico, pleno emprego, remuneração adequada e bem estar social (Harvey, 2005).

Este último aspecto, ("Welfare State") foi implementado de modos diferentes nos vários países industrializados de acordo com sua cobertura mais ou menos universal e nos países em desenvolvimento seu alcance foi bastante limitado, beneficiando basicamente os trabalhadores urbanos com contratos formais de trabalho. A sustentação financeira deste sistema de bem estar social nos países desenvolvidos, com algumas exceções de contribuições basicamente privados, dependia de forte aporte de recursos públicos por sua vez assegurados pelo sistema tributário que incidia sobre empresas e trabalhadores.

O equilíbrio dessa equação era parte do pacto tripartite mencionado anteriormente onde os partidos políticos, principalmente, social democratas e democrata cristãos; e os sindicatos foram seus maiores responsáveis nessa época. $O$ arranjo implicava na incorporação dos ganhos de produtividade do modelo "fordista" aos salários permitindo que os trabalhadores arcassem com percentuais significativos de tributos que sustentavam o sistema, além da contribuição das empresas. ${ }^{7}$

De acordo com essa concepção "keynesiana", o Estado administraria os serviços sociais e regularia o mercado tornando-se o mediador das relações e conflitos sociais (Dupas, 1999). Este esquema funcionou adequadamente enquanto vigorou o período de pleno emprego dos "30 anos dourados". Porém, quando as empresas começaram a reduzir postos de trabalho devido à inovação tecnológica e à descentralização da produção, o

\footnotetext{
${ }^{7}$ O sistema de proteção social nos EUA é uma exceção, pois sempre teve um importante componente privado e devido às mobilizações sindicais em grandes empresas, como na siderurgia e no setor automobilístico, implantaram-se vários fundos de pensão mantidos por empresas.
} 
financiamento do "Welfare State" entrou em crise porque ao mesmo tempo em que aumentou o número de usuários dos benefícios da rede de proteção social, reduziu-se a base tributária. As opções governamentais eram todas impopulares, pois implicavam em reduzir o alcance dos benefícios ou aumentar a tributação.

A pressão dos sindicatos, no entanto, prosseguia na busca de melhores salários e direitos e muitas greves foram vistas pela opinião pública como inconvenientes e meramente corporativas, particularmente na Inglaterra onde elas foram muito freqüentes na década de 1970.

As empresas, por sua vez, em sua busca por uma nova fase de acumulação começaram a pressionar pela redução de tributos e por eliminação dos regulamentos do "liberalismo engessado".

Todas essas circunstâncias geraram um clima favorável a mudanças políticas na direção conservadora. A conjuntura dos anos 1970 foi marcada por inflação e desemprego, e as novas gerações que não vivenciaram as agruras da Segunda Guerra Mundial não valorizavam os direitos assegurados pelo "Welfare State" da mesma forma que as gerações anteriores que lutaram pela sua implantação.

Houve um deslocamento geral das normas e valores coletivos - que eram hegemônicos, ao menos, nas organizações da classe operária e nos movimentos sociais das décadas de 1950 e 1960 - para um individualismo muito mais competitivo entendido como valor central de uma cultura empresarial que penetrou em muitos aspectos da vida (Harvey, 2004).

Os liberais reconstruíram seu discurso em novos patamares e nas eleições parlamentares de 1979, o Partido Conservador britânico liderado por Margareth Thacher conquistou a maioria parlamentar e ela se tornou Primeira Ministra do primeiro de uma série de governos neoliberais que se seguiriam até a atualidade.

As críticas de certos autores do pensamento neoliberal como Friedrich Von Hayek, Milton Friedman e James Buchanan à economia do "Welfare State", à intervenção do Estado na economia e ao modelo de economia planificada dos países do socialismo real transformaram-se em políticas de governo a partir da eleição dela, Reagan, Kohl e outros.

O mote central dessas políticas era, por meio da democracia política, promover o desenvolvimento da economia de livre-mercado. Isto implicaria em privatizar empresas pertencentes ao Estado, desregular o funcionamento dos serviços públicos, reduzir 
impostos, promover equilíbrio fiscal através da redução do custeio dos direitos sociais, reduzir custos de mão de obra eliminando direitos trabalhistas e conter os sindicatos.

Para Castells, as medidas que reduziram o poder do Estado trouxeram estabilidade para o sistema após a crise do "keynesianismo" (1999).

Porém, a mudança fundamental que ocorreu no poder e papel do Estado é que ele passou a servir principalmente a interesses privados. Como afirmou Chesnais:

As multinacionais são atualmente as instituições mais poderosas do mundo, mas sem a intervenção direta de governos como o de Thacher na Inglaterra a partir de 1979, o de Reagan nos Estados Unidos a partir de 1981 e em seguida de outros, não teriam conseguido implementar as políticas de liberalização comercial e de investimentos, bem como as políticas de desregulamentação, privatização e desmantelamento do 'Welfare State', tão rápida e radicalmente (1996).

Até meados da década de 1970, quando o "keynesianismo" entrou em crise, fortaleceu-se a visão neoliberal de que a regulação do Estado ameaçava a expansão capitalista e, portanto, era necessário libertar o capital do seu controle. Porém, o que a regulação realmente limitava era o poder e os ganhos do extrato populacional superior, em particular, nos países industrializados. Um estudo realizado pelos professores franceses Gerard Dumenil e Veronique Levy mostra a redução da apropriação da renda americana pela parcela de $1 \%$ mais rica da população de $48 \%$ em 1930 para 22\% em 1975, bem como a queda da relação de 1 para 16 entre as pessoas de maior e menor renda em 1930 para a metade nos anos posteriores a Segunda Guerra Mundial até 1975 (apud Harvey, 2005).

Entretanto, quando a desregulação do Estado começou, a situação se reverteu por meio do pagamento de altos salários, participação em lucros e resultados, especulação financeira e redução de impostos. A concentração de renda nos EUA em 1998 já retornara aos patamares de 1930 e os 0,1\% mais ricos que em 1978 se apropriavam de $2 \%$ da renda nacional passaram a $6 \%$ em 1999. A diferença entre os menores salários, em média, e os salários dos executivos nas empresas que era de 30 vezes em 1970 saltou para 500 vezes em 1999 (apud Harvey, 2005).

Estes dados apresentaram perfis semelhantes na Inglaterra, mas a concentração de renda não se limitou aos países centrais, pois apesar do desempenho medíocre de países em desenvolvimento como México, Brasil e outros durante as décadas de 1980 e 1990, começaram a aparecer milionários mexicanos e brasileiros entre os 500 mais ricos nas 
revistas "Forbes" e "Fortune". Todavia, o fenômeno foi mais severo nos países centrais, pois a diferença de renda entre seu quintil superior de renda e dos países em desenvolvimento, que, em média, era de 30 vezes em 1960, passou a 60 vezes em 1990 e 74 vezes em 1997 (Harvey, 2005).

Considerando, além disso, que o crescimento do PIB mundial tem sido baixo desde a segunda metade dos anos 1970, em média 2\%, ao contrário do comércio que cresceu em média $6 \%$, podemos concluir que a principal consequiência da mudança de paradigma foi a restauração do poder político da elite e das corporações multinacionais. Ou seja, o neoliberalismo não é um projeto meramente econômico e sim, em essência, político e de classe.

A discussão em torno do desenvolvimento do livre mercado nos termos mencionados, portanto, também introduziu o debate sobre a construção política do papel do Estado e sua relação com o indivíduo. Por isso, foi considerado "democrático", por exemplo, o estabelecimento de controle sobre os sindicatos, pois ao funcionarem como associações corporativas na defesa de seus interesses, se sobrepunham aos indivíduos e à sociedade. Thacher e Reagan deliberadamente procuraram enfraquecer o movimento sindical de seus países para levar sua política neoliberal adiante. A primeira deixou uma greve dos mineiros de carvão durar 400 dias sem fazer qualquer concessão e o segundo enfrentou uma greve de controladores de vôo demitindo todos sumariamente e cancelando o seu direito de trabalhar nesta profissão. Além disto, os dois introduziram uma série de novas leis para reduzir o papel dos sindicatos.

As grandes corporações multinacionais aproveitaram tanto a desregulação e a liberalização dos mercados nacionais, quanto a sua imbricação com as novas instituições financeiras internacionais (FMI, BIRD e OMC) para impulsionar a adoção de medidas neoliberais que além de favorecer sua rápida expansão mundial proporcionariam também a flexibilização e a desregulamentação da legislação trabalhista.

Precisamente por serem recomendados pelas instituições financeiras e outras organizações internacionais, além de "Think - tanks" e especialistas de diferentes origens, estes dois procedimentos em relação ao mercado de trabalho foram adotados mundialmente com mudanças nas legislações nacionais. 
Os principais objetivos das reformas trabalhistas implantadas nos anos 1980 e 1990 eram reduzir os custos de contratação e demissão dos trabalhadores. O primeiro objetivo implicava em reduzir ou eliminar os salários indiretos como o pagamento de horas extras, insalubridade, entre outros e transformar parte do salário em renda não tributável, por exemplo, através da concessão de auxílio alimentação, transporte, bônus, etc. O segundo objetivo buscava desvincular ao máximo as relações entre empresas e trabalhadores por meio da ampliação das possibilidades de subcontratações, terceirizações e redução dos entraves e compensações em caso de demissões sem justa causa.

A instabilidade do trabalho se generalizou devido à globalização e a reação dos trabalhadores se deu tanto no nível nacional quanto no internacional, embora obedecendo a táticas diferentes.

\section{O REGIME TRABALHISTA INTERNACIONAL}

\subsection{Introdução}

Após a Segunda Guerra Mundial constituiu-se, principalmente, nos países desenvolvidos o que Ruggie denominou de "liberalismo embutido" onde os processos inerentes ao mercado, bem como atividades empresariais e das corporações multinacionais foram "envoltos" por um conjunto de regulamentações sociais e políticas, embora o conteúdo delas fizesse parte da estratégia estatal de promoção do desenvolvimento industrial e econômico. Tratava-se a rigor de estabelecer a estrutura de uma nova ordem mundial que garantisse o multilateralismo das relações econômicas e políticas com estabilidade doméstica para evitar a repetição dos distúrbios dos anos 1930 (1983).

Esta nova ordem mundial implicava na introdução de uma série de acordos, mecanismos e organizações internacionais para dirigir o funcionamento da relação entre o multilateral e o doméstico, particularmente quanto aos aspectos do comércio, estabilidade monetária, desenvolvimento econômico, paz e segurança e até integração econômica como se tornou o caso da construção da União Européia.

Já tinham ocorrido iniciativas desde o final do século XIX de estabelecer organizações técnicas e administrativas para coordenar políticas internacionais comuns como a União Postal Internacional ou a União para a Proteção da Propriedade Intelectual, 
bem como outras que surgiram no bojo das negociações de paz ao término da Primeira Guerra Mundial, como a Liga das Nações de caráter mais político para assegurar a paz mundial ou, ainda, a OIT para promover um concerto social internacional.

Porém, as implantações mais consistentes de governança global ocorreram depois de 1945, particularmente, através dos tratados que estabeleceram a ONU, FMI, GATT, Banco Mundial e outras organizações internacionais. De acordo com Williamson, governança global é qualquer forma de criar ou manter ordem política e prover bens comuns para determinada comunidade política em qualquer nível (apud Risse, 2004).

Inicialmente, os atores que formalmente definiam e se responsabilizavam pela governança global eram essencialmente os Estados nacionais com certa exceção da OIT que preservou uma gestão com participação de empresários e trabalhadores desde seu início. Aliás, até hoje é a única organização internacional com esta característica. No entanto, mesmo neste caso particular, os Estados membros possuem 50\% dos votos nas deliberações e também recai sobre eles a responsabilidade de sustentar financeiramente seu funcionamento e a de transformar suas resoluções em normas nacionais.

Contudo, se a correlação de forças políticas no período dos "anos dourados" do capitalismo, pelo menos na maioria dos países industrializados, introduziu uma governança que possibilitou o estabelecimento do "Welfare state" e uma distribuição de renda mais equilibrada em benefício da maioria de suas sociedades, conforme os dados mencionados no capítulo anterior, a mudança nesta correlação, particularmente em favor do capital, permitiu a “acumulação pela 'despossessão"” (Harvey, 2005) por meio de estímulos e orientações viabilizados pelos aparatos políticos, econômicos e sociais das organizações internacionais e dos Estados nacionais.

Porém, houve reações nacionais e globais a este processo invertido de "acumulação" não apenas dos trabalhadores afetados pela perda de direitos e empregos como também por outros setores sociais prejudicados pela degradação ambiental ou pela perda de terras e propriedades ou, ainda, atores que ampliaram seu peso político como, por exemplo, as mulheres pela sua crescente participação no mercado de trabalho e em outras atividades sociais. Como já afirmava Karl Polanyi em sua importante obra "A grande transformação" ao analisar alguns dos efeitos da acumulação capitalista de épocas anteriores sobre o estado 
físico do homem e do meio ambiente e criticando a idéia do "mercado autoregulado": “...inevitavelmente a sociedade adotou medidas para se proteger" (2009).

A partir de determinados momentos, marcadamente as mobilizações dos anos $1960 \mathrm{e}$ a mudança de paradigma de acumulação na década seguinte, vários atores sociais buscaram influência na governança global por intermédio de ações e relações transnacionais, tema que será aprofundado mais adiante na dissertação.

Os teóricos que atribuem papéis de destaque para os atores não estatais nas relações internacionais, particularmente na emergência da globalização, têm se dedicado ao estudo da governança global, aplicada ao capitalismo global, direitos humanos, saúde, meio ambiente, sociedade civil global, entre outros, embora sem, necessariamente, constituir consensos sobre sua consistência teórica e prática. Por exemplo, Cox afirma que a governança global dos anos 1990 é, no mínimo, "nebulosa" porque há forte influência ideológica nesta conceituação pelos que fomentaram o neoliberalismo e porque pode haver exclusões de "Estados falidos" ou dos de menor desenvolvimento reduzindo o alcance da dimensão "global” (apud Murphy, 2005).

Por sua vez, Held e outros em sua análise sobre a globalização política concluíram que há um deslocamento das políticas Estado-centradas para uma nova governança global complexa e de múltiplas camadas devido a muitos processos políticos que se sobrepõem na atual conjuntura (apud Munck, 2003).

De fato, a idéia de governança global no tocante aos direitos fundamentais do trabalho, ao movimento social e ao sindicalismo pode ser encontrada em vários temas atuais que se sobrepõem ou se entrelaçam como o capitalismo global, os direitos humanos e a sociedade civil. Entretanto, a verificação se há uma governança global que considere os direitos dos trabalhadores em nível mundial será mais objetiva a partir da análise sobre a perspectiva de um regime trabalhista internacional, considerando que regimes internacionais são definidos como:

[...] grupos de princípios implícitos ou explícitos, normas, regras e procedimentos de decisão em torno dos quais as expectativas dos atores convergem em uma determinada área de relações internacionais. Os princípios são crenças de fatos e causalidades. As normas são padrões de comportamento definidos em termos de direitos e obrigações. As regras são prescrições ou proscrições para as ações e os procedimentos de decisões, as práticas para fazer e implementar as escolhas coletivas (Krasner, 1983). 
Não existe autoridade suprema ou governo no sistema internacional e, ainda por cima, detentor do monopólio legítimo da violência e assim capaz de impor a ordem mundial ou cumprimento das regras e normas dos regimes. Apesar disso, podemos falar em ordem no sistema internacional, ou, nas palavras de Rosenau, em "governança sem governo" como um conjunto de "atividades apoiadas em objetivos comuns que podem ou não derivar de responsabilidades legais e formais e não dependem, necessariamente, de poder coercitivo para que sejam aceitas...” (2000).

Ainda de acordo com Rosenau, a governança assegura a ordem por meio de entendimentos e arranjos que abrangem instituições governamentais e também mecanismos informais e não-governamentais ao contrário do governo que é somente formal e institucional (2000). Assim, governança é mais ampla do que governo e é também mais ampla do que um regime, pois este de acordo com a definição, mencionada anteriormente, é composto por princípios, normas, regras e procedimentos que convergem para uma determinada área de relações internacionais, o que define uma "questão" ou "área temática" menos abrangente e mais especializada (como, por exemplo, as normas internacionais de comércio ou as de trabalho) do que a ordem mundial regida pela governança (2000).

Portanto, os regimes são fontes de governança ao possibilitar que atores governamentais e não governamentais definam objetivos e persigam políticas em áreas particulares ou em busca do bem comum. Isso significa que os regimes internacionais estão encerrados na governança global e esta representa seus mecanismos de direção. (Rosenau, 2003).

Igualmente ao conceito de governança global e tantos outros aplicados às relações internacionais, a denominação regime internacional também possui aspectos contraditórios ou imprecisos a começar pela própria denominação que pode se confundir com a conceituação de modelos de política e também porque a definição mencionada no parágrafo anterior sugere certa rigidez conceitual.

No entanto, apesar de os regimes internacionais poderem ser embrionários ou decadentes, o seu sentido de cooperação internacional não tem nada de estático, pois eles podem mudar de acordo com suas dinâmicas internas e pela variação de fatores econômicos, sociais e políticos (Young, 1983). 
Para os teóricos realistas os regimes internacionais são estabelecidos pela pressão dos elementos que compõem o sistema internacional, particularmente, para responder aos desequilíbrios que podem surgir nos sub-sistemas como, por exemplo, os conflitos relativos à distribuição de renda ou a degradação ambiental. Porém, podem também ser concebidos como arranjos para administrar e limitar conflitos de interesse quando o Estado percebe que o "bem comum” não é distribuído espontaneamente (Haas, 1983).

Os regimes internacionais mais tradicionais possuem um importante caráter estatal pela sua formulação e implantação a partir dos acordos entre Estados Nacionais, pela governança no âmbito das organizações internacionais e pela aplicação prática por intermédio dos Estados Nacionais. Isto é, são Estado-centrados ou arranjos de "cima para baixo" como são especialmente os casos do sistema econômico mundial, o sistema mundial de segurança e, até mesmo, a OIT apesar da gestão tripartite mencionada anteriormente.

No entanto, ao contrário destes, os modelos modernos de governança asseguram sua eficiência por intermédio de uma forte incidência de setores não-estatais, em particular do movimento social e da opinião pública, o que caracteriza um arranjo de "baixo para cima". Porém, uma questão fundamental nos dois casos é saber em que medida podem mudar o comportamento de Estados Nacionais.

No modelo Estado-centrado isto seria possível desde que um determinado regime esteja vinculado a uma organização internacional com poder coercitivo no seu mandato e, principalmente, se o Estado Nacional optar por se tornar membro dela. Ao fazê-lo assume o compromisso de implementar nacionalmente as normas e regras implícitas ao regime utilizando seus próprios instrumentos legítimos de coerção. Portanto, a avaliação de custo benefício de tal filiação inclusive implica em avaliar vantagens e desvantagens de aceitar o eventual poder coercitivo das Organizações inerentes ao regime em questão.

Isso se aplica, por exemplo, no caso dos países que escolheram se tornar membros da OMC porque avaliaram que o benefício de participar do sistema mundial de comércio sob as regras de liberalização comercial que ela administra é mais vantajoso do que se manter excluído, mesmo com a possibilidade de sofrer uma sanção econômica na hipótese de eventual descumprimento das suas normas e regras.

Entretanto, há poucas instituições internacionais que possuem algum poder de coerção em nível internacional com a possibilidade de ser aplicado aos Estados Nacionais. 
Uma delas é a União Européia pela sua institucionalidade e normatização que inclui a possibilidade de sanções por desrespeito às suas normas, regra acordada e aceita pelos seus membros e outra é a própria OMC pela sua capacidade de aplicar sanções comerciais. Porém, a instituição com poder coercitivo mais abrangente é o Conselho de Segurança da ONU, mas que ainda assim exclui seus cinco membros permanentes com poder de veto da possibilidade de sofrer sanções.

Este quadro demonstra que, na prática, não existe hierarquia formal na direção do sistema internacional e nada que possa ser comparável à estrutura estatal nacional (Risse, 2004). Portanto, no arranjo Estado-centrado ou de "cima para baixo", os regimes internacionais somente obterão a anuência e cooperação dos Estados Nacionais pelo convencimento ou pela coerção exercida por Estados Nacionais mais poderosos. Porém, para isso acontecer, dependerá sobremaneira dos interesses em jogo, da agenda em questão e da conjuntura do momento.

A nossa hipótese é que as ações transnacionais e/ou locais de atores não-estatais podem convencer Estados Nacionais a adotarem medidas para que as regras e normas internacionais sejam cumpridas ou ainda, que alguns dos atores privados como, por exemplo, empresas, podem também ser convencidas a cumpri-las voluntariamente.

\subsection{O regime trabalhista internacional Estado-centrado}

O conteúdo das regras e normas que se busca fortalecer na governança global atual emana, sobretudo, de regimes internacionais Estado-centrados, a exemplo dos direitos humanos universais, da preservação do meio ambiente e também dos direitos fundamentais do trabalho.

Por isso, começaremos pela descrição dos diferentes arranjos do regime internacional de trabalho considerando seus princípios, regras, normas, modos de direção e atores para verificar seus limites e possibilidades diante da flexibilização de direitos trabalhistas e instabilidade do mercado de trabalho num contexto de redução da presença do Estado na economia, fenômenos que se intensificaram a partir dos anos 1980. 
As medidas introduzidas naquele momento para promover o mercado auto-regulado provocaram alguns debates sobre a ordem econômica e social desejável, no entanto sem soluções convincentes. Contudo, a pressão política pela regulação dos negócios e, em particular, das atividades das EMNs cresceu anos 1990, inicialmente, devido às acusações contra grandes empresas mineradoras e petroleiras por abusos de direitos humanos nas suas áreas de operação, bem como pelos rumores de seu envolvimento no fomento de conflitos armados e golpes de Estado para favorecer a aquisição de concessões e posteriormente quando se tornou público de que havia abusos de todo tipo também em outros setores produtivos (Rathgeber, 2006).

Os principais regimes de trabalho Estado centrados em consideração na dissertação são a OIT, com destaque para suas normas de trabalho fundamentais; as "Diretrizes para empresas multinacionais da OCDE" e os arranjos incluídos em alguns tratados de integração regionais. Além destes, há iniciativas para tentar fortalecer o arranjo Estado centrado.

\subsubsection{A OIT e as Normas Fundamentais de Trabalho}

Até o final do século XIX e início do século XX, houve várias tentativas de promover encontros governamentais supranacionais com o intuito de discutir a aprovação de leis comuns relativos ao trabalho e criar mecanismos para aplicá-las. Por exemplo, em 1900 durante um destes encontros foi fundada a Associação Internacional de Legislação do Trabalho, que realizou diversas conferências posteriores, e de certa maneira foi uma precursora da OIT.

A primeira revolução socialista na forma prevista por Marx ocorreu na Rússia em 1917, paradoxalmente num país onde nem o capitalismo estava tão adiantado e nem o proletariado era tão expressivo se comparado com Inglaterra, França ou EUA. No entanto, esta revolução convenceu muitos governantes de que a questão social deveria ser tratada 
com maior atenção e concerto daí por diante. Inclusive, os dois primeiros países a constitucionalizarem direitos trabalhistas foram a URSS e o México, país que também passou por um processo revolucionário entre 1910 e 1918, embora com desdobramentos muito diferentes da russa.

A Primeira Guerra Mundial terminou em 1918 com a derrota da Alemanha e seus aliados e no bojo das negociações de paz em Versalhes também havia preocupações em relação à "questão social”, pois terminada a guerra, os trabalhadores voltaram a pressionar pelo atendimento de suas reivindicações e o exemplo da Revolução Russa estava muito presente, além das tentativas revolucionárias debeladas na Alemanha e Hungria logo após o fim da guerra.

Além disso, aos EUA, que já despontava como potência mundial, interessava a paz na Europa e a introdução de regras que favorecessem o livre comércio para expandir sua economia Este item fazia parte da proposta dos "14 pontos para a paz" apresentados pelo então presidente Woodrow Wilson durante as conversações em Versalhes.

Esta visão liberal favoreceu a criação da Organização Internacional do Trabalho como um instrumento para igualar as condições de competitividade entre as nações e liberalizar o comércio sem por os níveis de vida em perigo (Polanyi, 2009).

Por fim, um setor importante dos socialistas em nível mundial já não era partidário da revolução proposta por Marx e sim a favor de reformas, cujo espírito seria contemplada na parte XIII do Tratado de Versalhes que aprovou a criação da OIT e uma "Carta de Trabalho" que, por sua vez, apresentou uma série de princípios, entre eles:

[...] o trabalho não é uma mercadoria; a liberdade de expressão e de associação é essencial para o progresso constante; a pobreza em qualquer lugar constitui um perigo para a prosperidade de todos; a luta contra a necessidade deve prosseguir com energia incessante em cada nação e mediante um esforço internacional, contínuo e concertado, no qual os representantes dos trabalhadores e empregadores, colaborando em pé de igualdade com os representantes dos governos, participem em discussões livres e em discussões de caráter democrático com o fim de promover o bem estar comum (OIT, 1998).

Particularmente, o último princípio que propunha o concerto tripartite, rompia com o materialismo histórico de transformação social via luta de classes e revolução.

Todo o funcionamento da OIT é tripartite. Desde a composição de seu Conselho de Administração - 28 representantes governamentais, 14 dos trabalhadores e 14 dos 
empresários - passando pelo quadro funcional do escritório sede em Genebra e de outras estruturas regionais ou nacionais, até a composição de reuniões de mera consulta, embora nas votações os governos representem $50 \%$ e os trabalhadores e empregadores $25 \%$ cada.

Além de defender seus princípios, o papel da OIT é elaborar normas trabalhistas, estimular sua implantação nos países membros e promover sua aplicação. Elas se expressam por meio de convenções, recomendações e declarações e sua figura jurídica mais importante é a convenção que normalmente vem acompanhada por uma ou mais recomendações. Todas são negociadas e aprovadas nas Conferências Anuais da OIT que, formalmente, é a instância máxima da organização composta por delegações tripartites de cada Estado membro.

Nestas conferências debatem-se vários aspectos do tema trabalho e há um mecanismo para que as convenções e recomendações afins sejam negociadas e aprovadas. Além desta atividade anual, ocorrem, periodicamente, reuniões especiais sobre temas específicos que também podem aprovar recomendações e declarações.

Uma vez aprovada uma convenção, ela é submetida à apreciação de cada Estado Nacional membro da OIT que por sua vez decide se a ratifica ou não. Uma vez ratificada, a legislação nacional deve ser adaptada ao conteúdo da convenção da melhor maneira possível para assegurar sua eficácia.

É possível relacionar os temas em discussão nas convenções com aspectos conjunturais de cada momento ao longo deste quase um século. A Convenção número 1 , por exemplo, tratou da regulamentação da jornada de trabalho na indústria e as demais que foram aprovadas entre 1919 e 1939 (início da II Guerra Mundial) tratavam também de várias reivindicações dos trabalhadores que vinham sendo defendidas desde o século XIX, como a proteção ao desemprego, à maternidade, ao trabalho noturno, aos acidentes de trabalho; idade mínima para o trabalho na indústria; descanso semanal; seguro contra doença, velhice, invalidez e morte; etc.

Os temas tratados durante o período da "guerra fria" - 1948 a 1989 - buscavam fortalecer os mecanismos de concerto social do "liberalismo embutido". As convenções dessa época tratavam de liberdade sindical, negociação coletiva, trabalhadores migrantes, política de emprego, discriminação, igualdade de pagamento, representação sindical, 
estatística de trabalho, servidores públicos, trabalho forçado ${ }^{8}$, entre outros e tratavam também das "modernas" ameaças à saúde no trabalho devido ao contato com radiações, benzeno, amianto e a possibilidade de adquirir diferentes cânceres.

O novo paradigma de acumulação e o neoliberalismo, também influenciaram o mecanismo de formulação de normas e seu conteúdo. Os temas discutidos eram relacionados às novas formas de trabalho, como a convenção sobre trabalho em tempo parcial, o trabalho a domicílio, intermediação de trabalho, créditos em caso de falência, entre outros, no entanto, com formulações menos determinativas em comparação com as normas anteriores.

Atualmente, há mais de 170 países membros da OIT e cerca de 200 convenções aprovadas. Aproximadamente $25 \%$ referem-se a normas específicas sobre os direitos de trabalhadores no mar que por esta razão vivem uma situação particular.

Entre o conjunto de convenções, existe um núcleo que têm origem em normas internacionais de direitos humanos fundamentais. São as oito convenções e suas recomendações que tratam da promoção da liberdade sindical e da negociação coletiva, bem como da proteção contra trabalho forçado, trabalho infantil e discriminação de qualquer espécie no mercado de trabalho.

O núcleo também tem sido denominado de "Normas Fundamentais do Trabalho" e é composto pelas Convenções 87 de 1948 sobre a Liberdade Sindical e o Direito de Sindicalização; 98 de 1949 sobre o Direito de Sindicalização e Negociação Coletiva; 29 de 1930 sobre o Trabalho Forçado; 105 de 1957 sobre a Abolição do Trabalho Forçado; 138 de 1973 sobre Idade Mínima; 182 de 1999 sobre Abolição das Piores Formas de Trabalho Infantil; 100 de 1951 sobre Igualdade de Remuneração e a 111 de 1958 sobre Discriminação no Emprego e Ocupação.

Essas convenções são consideradas fundamentais, porque se pressupõe que, se forem plenamente respeitadas, os trabalhadores serão capazes de defender seus próprios interesses. Se todos puderem se organizar livremente e negociar periodicamente seus contratos de trabalho com os empregadores, sem ter que competir no mercado de trabalho

\footnotetext{
${ }^{8}$ Trabalho forçado é um termo espanhol que significa trabalho escravo. Em 1957 aprovou-se a Convenção 105 que proibia o trabalho forçado de prisioneiros de consciência ou por razões político-ideológicos. Era uma medida voltada à condenação dos "Gulags" da URSS e dos "campos de reeducação" na China e outros.
} 
com escravos e crianças ou com grupos sociais que são discriminados e trabalham por menos, em tese os contratos seriam justos e construídos de forma democrática.

As eventuais violações de qualquer norma da OIT podem ser denunciadas por intermédio da apresentação de queixas que serão analisadas nas suas diferentes instâncias. Inicialmente os comitês que tratam dos diferentes assuntos solicitarão esclarecimentos ao governo do país em questão e posteriormente à luz dos fatos emitirão pareceres reconhecendo ou não ou em parte, a procedência da queixa e farão também alguma recomendação para lidar com o problema. Se a queixa for sobre violação da liberdade sindical, ela será tratada pelo Comitê de Liberdade Sindical do Conselho de Administração que se reúne três vezes ao ano para analisar os casos apresentados.

Em cada conferência anual, uma Comissão de Aplicação de Normas se reúne para discutir e emitir resoluções sobre o desenvolvimento da aplicação das normas no geral e em países específicos. O segundo caso, normalmente, envolve países onde determinadas normas são violadas de forma contumaz e visa pressioná-los, pelo menos moralmente, para que corrijam o problema. Os casos piores são mencionados num "parágrafo especial" da resolução. Há ainda a possibilidade de ser aprovado um monitoramento direto do problema por meio de comissões de investigação ou da instalação de um representante especial e permanente da OIT no país em questão. No limite, o país acusado pode perder o direito de voto na organização conforme prevê o Artigo 33 da Constituição da organização.

O conjunto de normas da OIT forma um arcabouço jurídico de direitos que, pela articulação entre sua formulação em nível internacional e suas ratificações nacionais deveria implicar em ampla aceitação e representar um regime eficaz. Porém, isto está longe da realidade, pois falta muito para assegurar que as normas sejam respeitadas universalmente e, particularmente, ao longo dos últimos anos, ficou claro que a OIT, embora Estado - centrada, não possui "dentes" para coagir seus membros a serem mais exigentes em garantir o cumprimento local, pelo menos, das convenções fundamentais.

No entanto, ao longo dos últimos anos, suas "Normas Fundamentais de Trabalho" tornaram-se a referência para a criação de novos mecanismos de proteção dos direitos trabalhistas e também para fortalecer o funcionamento da própria OIT. Além da referência para os arranjos centrados no Estado, as "Normas" também se tornaram referência para os arranjos de "baixo para cima" que contam com maior incidência social e sindical. 


\subsubsection{As Diretrizes para Empresas Multinacionais da OCDE;}

Quando o Plano Marshall foi aceito pelos países europeus em 1948, foi criada uma instituição para coordenar a aplicação de seus recursos denominada Organização Européia para a Cooperação Econômica (OECE) que em 1961 mudou suas funções, bem como seu nome para Organização para a Cooperação e Desenvolvimento Econômico (OCDE). A partir deste momento os países considerados industrializados em todo o mundo e não apenas da Europa e Estados Unidos, passaram a fazer parte da organização e suas funções eram reunir informações e desenvolver políticas nas áreas do comércio e investimentos para promover o crescimento e desenvolvimento econômico.

Hoje há 30 países membros da organização ${ }^{9}$, além de alguns, como o Brasil, que participam com o status de observador.

A OCDE possui várias diretorias e dois órgãos consultivos: a "Trade Union Advisory Committee" (TUAC) que representa os trabalhadores e que é composta e sustentada financeiramente pela maioria das centrais sindicais dos países membros e a "Business and Industry Advisory Committe" (BIAC) que representa os empresários.

A organização elaborou sua primeira versão das "Diretrizes para Empresas Multinacionais" em 1976, com o intuito de oferecer algumas recomendações para uma conduta empresarial responsável e evitar que se alocassem simplesmente para obter vantagens de regimes regulatórios menos restritos nos países em desenvolvimento (Clapp; Utting, 2008: 1).

Elas foram revistas duas vezes. Em 1992 para adaptá-las à nova conjuntura da globalização e, finalmente, entre 1999 e 2000, os países membros aceitaram incluir também uma série de referências a normas trabalhistas e ambientais. Quanto às normas trabalhistas, o termo de referência foi a "Declaração de Princípios e Direitos Fundamentais" da OIT e quanto às normas ambientais, foi principalmente a "Declaração do Rio sobre Meio Ambiente e Desenvolvimento" (IOS, 2004).

\footnotetext{
${ }^{9}$ Os países membros são a Alemanha, Austrália, Áustria, Bélgica, Canadá, Coréia do Sul, Dinamarca, Eslováquia, Espanha, EUA, Finlândia, França, Grécia, Holanda, Hungria, Islândia, Irlanda, Itália, Japão, Luxemburgo, México, Noruega, Nova Zelândia, Polônia, Portugal, Suécia, Suíça, Reino Unido, República Tcheca e Turquia.
} 
Além dos países membros da OCDE, outros quatro que não são membros como a Argentina, Brasil, Chile e Eslováquia também aderiram às "Diretrizes". Embora o cumprimento delas pelas EMNs seja voluntário, a versão de 2000 apresentou uma novidade que foi a criação de um sistema de apresentação de queixas e conciliação, em caso de desrespeito a elas pelas empresas multinacionais. As reclamações devem ser dirigidas aos "Pontos de Contato Nacionais" (PCN) dos países que aderiram às "Diretrizes" ou ao PCN do país sede da empresa em questão ou ainda, diretamente à OCDE. O papel dos pontos de contato é tentar colocar as partes "em contato" para estimular a solução de pendências por meio do diálogo e negociação (TUAC, 2002).

O PCN pode ser um representante do governo ou uma comissão tri ou quadripartite ${ }^{10}$. De acordo com a revista do Instituto Observatório Social, as "Diretrizes" estão divididas em quatro partes que são os princípios gerais, divulgação de informações, normas de trabalho e questões específicas. Os princípios gerais são os seguintes:

1) Colaborar com o progresso econômico, social e ambiental.

2) Respeitar os direitos humanos e os compromissos internacionais assumidos pelos paises onde tenham unidades.

3) Estimular a criação de capacidades locais em cooperação com a comunidade.

4) Criar oportunidades de emprego e estimular a formação profissional.

5) Abster-se de procurar ou aceitar exceções não previstas no quadro legal ou regulamentar, em domínios como o meio ambiente, a saúde, a segurança, o trabalho, a tributação, os incentivos financeiros ou outros.

6) Desenvolver e aplicar as boas práticas de gestão empresarial.

7) Estabelecer práticas que promovam uma relação de confiança mútua entre as empresas e as sociedades.

8) Divulgar para os trabalhadores as políticas da empresa e estimular que suas ações sejam adequadas a elas.

9) Não perseguir trabalhadores que denunciem práticas que contrariem a lei, as Diretrizes ou as políticas da empresa.

10) Estimular os fornecedores e terceirizados a ter também uma conduta empresarial adequada às Diretrizes.

11) Evitar qualquer ingerência indevida em atividades políticas locais. (2004)

As informações que as "Diretrizes" mencionam dizem respeito, em primeiro lugar, às atividades, estrutura, razão social, endereços, entre outras, das empresas. Em segundo lugar, à contabilidade e aspectos financeiros. Terceiro, a composição do controle acionário, do

\footnotetext{
${ }^{10}$ Comissão quadripartite significa a presença também de ONG's e organizações sociais, além de governo, empresários e sindicatos.
} 
conselho de administração e da diretoria. Em quarto lugar, informações sobre fatores e sistema de gestão de riscos relevantes e previsíveis. Por último, a disseminação de informações sobre alterações no processo produtivo como o encerramento de atividades e unidades, bem como sobre as políticas de gestão da empresa. (IOS, 2004).

Quanto às normas de trabalho, as "Diretrizes" reafirmam os direitos fundamentais e os temas da Declaração Tripartite sobre Empresas Multinacionais e Política Social da OIT mencionada mais adiante na dissertação. Além disto, assumem o compromisso de respeitar padrões de trabalho não menos favoráveis que os observados por outras empresas da mesma dimensão e setor; tomar medidas para garantir saúde e segurança no trabalho; empregar o maior número possível de pessoal local; informar os representantes dos trabalhadores sobre alterações que possam afetá-los e cooperar para atenuar os efeitos adversos; não influenciar de maneira desleal as negociações com os representantes dos trabalhadores e nem prejudicar seu direito de associação mediante ameaças de transferência de unidades ou trabalhadores para outro local e permitir que os representantes dos trabalhadores negociem acordos coletivos de trabalho ou termos de relações entre trabalhadores e empregadores (IOS, 2004).

Por fim, os itens específicos dizem respeito ao meio ambiente, combate à corrupção, interesses dos consumidores, ciência e tecnologia, concorrência e tributação (IOS, 2004).

\subsubsection{O regime trabalhista internacional nos acordos de integração regional}

O advento de numerosos tratados regionais de integração econômica a partir do final dos anos 1980 foi visto pelo movimento sindical como mais um movimento para liberalizar a circulação de capitais e ampliar a competitividade empresarial trazendo novas ameaças aos direitos e condições de trabalho.

A sua reação quase unânime foi reivindicar a incorporação de padrões trabalhistas fundamentais, referenciadas na OIT, nos tratados assinados pelos países participantes, na prática mais um exemplo de regime trabalhista Estado-centrado. Há vários casos onde isso ocorreu de alguma forma como resultado dessa pressão e serão descritas três experiências 
importantes devido ao peso de suas economias e às características do regime trabalhista que adotaram. Trata-se da União Européia (UE), do Acordo de Livre Comércio da América do Norte (Nafta) e do Mercado Comum do Sul (Mercosul).

Com exceção da experiência pioneira e mais profunda da UE que já atingiu o estágio de união monetária e também admite a livre circulação de pessoas, o Mercosul ainda é uma União Aduaneira Incompleta ${ }^{11}$ e o Nafta não tem a pretensão de ser mais do que uma área de livre trânsito de capitais através do comércio e investimentos entre Canadá, Estados Unidos e México.

O temor de que a padronização de procedimentos comerciais entre países com estágios de desenvolvimento muito diferenciados pudesse nivelar os padrões trabalhistas por baixo levou os sindicatos nos três casos a reivindicarem a introdução de cláusulas nos respectivos tratados comerciais ou de integração que obrigassem os países participantes a respeitar um patamar mínimo de normas trabalhistas e sociais.

A União Européia acelerou a implantação de políticas de cunho social a partir da aprovação da “Ata Única Européia” em 1985, bem como de políticas de emprego quando seus países membros adotaram as medidas previstas no "Livro branco do mercado único"12 de Jacques Delors a partir de 1993, principalmente, a eliminação de barreiras comerciais não tarifárias, ampliando a circulação de capitais no interior do bloco que, a esta altura, possuía 12 Estados membros.

Anteriormente já haviam sido adotadas algumas medidas para facilitar a livre circulação de pessoas entre os países da UE como as autorizações para os cidadãos

\footnotetext{
${ }^{11}$ É uma "União Aduaneira" porque possui tarifa externa comum (TEC) em relação a países externos ao Mercosul e é incompleta porque cada país tem uma lista de produtos que não seguem a TEC.

12 O "Livro branco" foi um relatório encomendado em 1984 pelo presidente da Comissão Européia sobre o estado da integração européia e que descreveu os obstáculos físicos, técnicos e fiscais ainda remanescentes a livre circulação de bens e serviços.
} 
trabalharem e viverem em outro país membro, o direito de votar e ser votado no país de residência, apresentação de documento de identidade comum em algumas das fronteiras invés de passaporte, equiparação de currículos de profissionais liberais para efeito de trabalho em outro país, formação universitária integrada possibilitando iniciar a graduação num país e concluir ou fazer parte do estudo em outro, medidas de proteção aos consumidores e regras ambientais.

No tocante ao regime trabalhista também houve iniciativas visando estabelecer patamares mínimos de direitos trabalhistas a serem respeitados pelas empresas em qualquer país da UE onde se estabelecessem. Embora o fortalecimento destes direitos seja de interesse dos sindicatos, o seu objetivo também era o de impedir a competição desleal entre empresas de um país e outro por meio da prática de "Dumping Social", isto é, a redução de padrões trabalhistas para diminuir custos e ganhar competitividade.

Embora houvesse uma proposta de "Carta Social" que data dos anos 1960, as tentativas mais eficientes de introduzir uma dimensão social à "Comunidade Européia" somente ocorreram a partir da entrada em vigor da "Ata Única" em 1987 que eliminou totalmente as restrições ainda vigentes à livre circulação de pessoas e propunha aprovar uma legislação trabalhista e social comum.

No entanto, não houve consenso governamental quanto a este último aspecto, mas ainda assim foram aprovadas algumas normas trabalhistas com alcance comunitário quanto à saúde e segurança no trabalho, além de uma diretriz para fixar os princípios gerais das eventuais reformas da legislação trabalhista promovidas pelos Estados membros.

A "Ata Única" também introduziu o conceito do "diálogo social" entre os "parceiros" do mercado de trabalho com o intuito que Confederações de Trabalhadores e Associações Empresariais pudessem se colocar de acordo sobre determinados direitos e 
procedimentos uma vez que no nível governamental não se chegava a acordos sobre a proteção dos trabalhadores, principalmente, diante das novas formas "atípicas" de trabalho como o subcontratado, a domicílio, a tempo parcial, entre outros, além da promoção de formas avançadas de "democracia industrial", embora o "diálogo" tampouco produzisse resultados num primeiro momento (Santaniello, 1999).

Em 1989 foi aprovada uma "Carta de Direitos Sociais Fundamentais" pelo Conselho Europeu (CE), órgão máximo da então Comunidade Econômica Européia $(\mathrm{CEE})^{13}$ que, no entanto, não obteve efeitos vinculantes ao Tratado de Roma que a estabeleceu e se transformou em uma declaração de princípios sem nenhum efeito jurídico Para superar este problema, onze membros da UE, com exceção da Inglaterra, aprovaram um protocolo anexo ao Tratado de Maastrich que permitia ao Conselho interferir nas políticas sociais do bloco exceto quanto a salário, direito de greve dos trabalhadores e "lock out" das empresas.

O conteúdo das eventuais interferências quanto a condições de trabalho e elementos concernentes á "democracia industrial" como informação e consulta aos trabalhadores, seriam decididas no Conselho Europeu por maioria qualificada de votos. Outras questões relacionadas a proteção social e defesa de interesses coletivos dos trabalhadores seguem dependentes de consenso dos membros do CE.

O protocolo também estabeleceu o direito de empresários e trabalhadores, através de suas organizações centrais, serem consultados e poderem interferir em propostas do CE sobre novas normas comunitárias relacionadas a questões sociais. Desta forma estabeleceram-se, no âmbito comunitário, as diretrizes para licença maternidade, trabalho

\footnotetext{
${ }^{13}$ Em 1951 foi criada a Comunidade Européia do Carvão e do Aço (CECA) com seis países que se transformou em Comunidade Econômica Européia (CEE) em 1957 e em 1992, já com 12 membros, se transformou em União Européia a partir da aprovação do Tratado de Maastrich.
} 
em tempo parcial e mecanismos de consulta entre empresários e dirigentes sindicais. (Santaniello, 1999).

Por fim, foi aprovada uma diretriz que permite estabelecer "Comitês de Empresas Europeus" de 3 a 30 membros em EMNs com mais de mil empregados atuando em mais de um Estado membro da UE. Uma vez acordado que o Comitê será estabelecido, as partes definirão um Estatuto que regerá seu funcionamento e o apoio que será provido pela empresa como, por exemplo, o custeio da tradução. A obrigação legal que a empresa tem se o Comitê for estabelecido é o de informar e consultá-lo, pelo menos uma vez ao ano sobre suas estratégias empresariais como investimentos, reestruturação, demissões e novos produtos.

Além destas normas e regras, os representantes dos trabalhadores na Europa têm assento em diversas instituições comunitárias, em particular, no Conselho Econômico e Social junto com os empresários e representantes do chamado "Terceiro Setor" que são outras organizações da sociedade civil.

Percebe-se que a normatização européia no que tange ao regime trabalhista define princípios e mecanismos que privilegiam o entendimento direto entre trabalhadores e empresários sobre a forma mais adequada de contemplar determinadas demandas.

Porém, em outros processos não é assim. A integração econômica na América do Norte, desde o início, teve um caráter muito diferente da experiência européia, pois se limitou à livre circulação de capitais. O primeiro passo foi o "Canada United States Free Trade Agreement" (Cusfta) que entrou em vigor em janeiro de 1989, liberalizando ainda mais as relações comerciais entre o Canadá e Estados Unidos. Em 1994 este tratado foi substituído pelo Nafta ao incluir o México e reafirmar praticamente o mesmo conteúdo do Cusfta. 
Trata-se de um Tratado de Livre Comércio muito detalhado, com mais de um milhar de itens e sub-itens, mas que basicamente trata de desgravação tarifária, regras de origem, unificação de padrões técnicos, compras governamentais, regras de investimentos, política de competitividade, comércio de serviços, direitos de propriedade intelectual, direitos de entrada temporária para comerciantes profissionais, entre outros.

Cabe destacar também que o Nafta não aborda políticas de migração nem o movimento de trabalhadores através das fronteiras, exceto a entrada temporária de profissionais e executivos (Compa, 1998).

$\mathrm{O}$ anúncio do fim das negociações e a chegada a um acordo entre os três países em agosto de 1992 deu-se exatamente quando a disputa eleitoral entre George Bush e Bill Clinton se acirrava. O movimento sindical, organizações ambientais e grupos de defesa dos direitos humanos pressionavam Clinton para repudiar as negociações do Nafta, pois consideravam este tratado uma peça da agenda neoliberal que favorecia as empresas transnacionais e investidores à custa dos trabalhadores e do meio ambiente. Porém, a candidatura democrata dependia muito do respaldo financeiro da comunidade empresarial e dos investidores, a quem o Nafta interessava e muito (Compa, 1998).

A opção adotada por Clinton e anunciada num discurso pronunciado na Universidade de Carolina do Norte em 4 de outubro de 1992 foi a de apoiar o Tratado negociado e trabalhar pela sua aprovação no Congresso, desde que incluísse acordos complementares em matéria trabalhista e ambiental. Desta maneira, nasceram e foram assinados em setembro de 1993 os "acordos paralelos" North American Agreement on Labor Cooperation (NAALC) - Acordo Norte- Americano de Cooperação sobre o Trabalho - e North American Agreement on Environment Cooperation (NAAEC) - Acordo NorteAmericano de Cooperação sobre Meio Ambiente.

O NAALC é um instrumento detalhado e de complexa aplicação, mas que não tem caráter vinculante, o que significa que o seu cumprimento depende da vontade dos governos de cada país. É enfático nas suas declarações de respeito à soberania de cada um no tocante à aplicação da legislação trabalhista nacional e não cria nenhum tribunal ou órgão decisório de caráter supra-nacional para decidir sobre o mérito do respeito ou não às normas de trabalho. Podemos dividir os compromissos assumidos em quatro níveis:- 
1. A importância de novas oportunidades de emprego e de melhoria das condições de trabalho e níveis de vida, citadas no seu preâmbulo e nos objetivos;

2. Onze princípios mencionados no Anexo 1 a serem observados pelos três países: liberdade de associação e proteção ao direito de organização, direito à negociação coletiva, direito à greve, proibição do trabalho forçoso, restrições sobre o trabalho de menores, condições mínimas de trabalho, eliminação da discriminação no emprego, salário igual para homens e mulheres, prevenção de lesões e doenças ocupacionais, indenização em caso de ocorrência destas, proteção aos trabalhadores migrantes;

3. Obrigações nas áreas de legislação e aplicação no tocante a níveis de proteção, ações governamentais para aplicação da legislação trabalhista, ações individuais, garantias processuais, publicidade, informação e conhecimentos públicos;

4. A obrigação assumida é a de "aplicar efetivamente sua legislação trabalhista" no que tange a Salário Mínimo, Trabalho Infantil e Segurança e Saúde Ocupacional (os três compromissos fundamentais).

É no último parágrafo que reside a essência da aplicação do NAALC, pois nele define-se a aceitação, pelos três países, de investigações inclusive internacionais sobre o cumprimento das respectivas leis nacionais referentes aos três compromissos, porém a partir de determinada estrutura e procedimentos.

A estrutura do NAALC inclui uma Comissão para Cooperação Trabalhista, três "National Administrative Offices" (NAO) - Escritórios Administrativos Nacionais, um Comitê Avaliador e a possibilidade de instalar Painéis Arbitrais.

A Comissão é composta por um Conselho Ministerial e um Secretariado. Do Conselho participam os Ministros ou Secretários de Trabalho do Canadá, EUA e México e é a instância máxima, inclusive para decidir sobre a instalação de painéis ou não, no caso de queixas analisadas em instâncias inferiores sobre a violação dos três compromissos fundamentais. O Secretariado tem sede em Dallas, no Texas, e é composto por 15 técnicos originários dos três países membros, bem como um staff burocrático. É coordenado por um Diretor Executivo, com ajuda de um Diretor para Legislação Trabalhista e Análise Econômica e um Diretor para Cooperação e Avaliação, cargos preenchidos pelos três países e com mandatos rotativos a cada três anos. Sua responsabilidade é produzir informes comparativos sobre legislação e mercado de trabalho da região, além de estudos 
específicos. É o braço administrativo da Comissão Ministerial, bem como dos Comitês de Especialistas ou dos Painéis Arbitrais que eventualmente venham a ser instalados.

Há um NAO em cada país-membro com o papel de receber as queixas apresentadas, com a característica que o indivíduo, grupo ou entidade(s) reclamante não pode apresentar queixas sobre a violação de direitos em seu próprio país. Somente pode se referir a violações ocorridas nos outros dois. Um dos encaminhamentos adotados pelos NAOs é o de promover consultas junto a instituições do país acusado. Os NAOs do Canadá e EUA têm promovido audiências públicas no trato das queixas, mas o escritório do México não.

O Comitê Avaliador de Especialistas pode ser instalado, inclusive, em caráter internacional, sobre cada assunto incluído nos princípios do NAALC, desde que o tema esteja relacionado com comércio, que a(s) empresa(s) acusada(s) atue(m) no âmbito do Nafta em pelo menos dois países e que ambos tenham legislação sobre o assunto podendo funcionar mais de um Comitê ao mesmo tempo.

Para um Painel Arbitral ser instalado, pelo menos, dois Ministros devem concordar e ele tratará exclusivamente dos três compromissos fundamentais. Tem o poder de aplicar multas, se constatado descumprimentos e os recursos provenientes delas destinar-se-ão a promover a legislação do tema violado. Em caso de recusa de pagamento poder-se-á aplicar sanções comerciais. É permitido funcionar mais de um Painel, concomitantemente.

O movimento sindical dos três países tem tentado utilizar os procedimentos e instrumentos de avaliação do NAALC para enfrentar o comportamento de certas EMNs após a entrada em vigor do Nafta, mas afirmam que os resultados são pobres devido ao caráter voluntário do acordo e a complexidade de seu funcionamento.

O Mercosul, por sua vez, sofreu inspirações de processos anteriores de integração econômica ocorridas na América Latina durante a vigência dos modelos econômicos de substituição de importações e da própria União Européia, mas começou a vigorar de fato já sob os auspícios do paradigma neoliberal quando Argentina, Brasil, Paraguai e Uruguai assinaram o Tratado de Assunção em 1991.

Hoje, além destes quatro países, associaram-se ao Mercosul, por meio de acordos especiais, o Chile, a Bolívia e o Peru. A Venezuela solicitou ingresso como membro pleno, o que, no entanto, ainda está pendente. 
O Mercosul é um acordo que almeja chegar a uma integração mais ampla do que a existente, mas sua institucionalidade é pequena e centralizada. As suas resoluções são tratadas desde o início, supranacionalmente, pelo Conselho do Mercado Comum (CMC) composto pelos Chefes de Estado - Presidentes - dos países membros plenos e pelo Grupo Mercado Comum (GMC), um organismo executivo composto por quatro membros por país, incluindo obrigatoriamente os Ministros da Economia e das Relações Exteriores, que responde ao CMC (Oliveira, 2003).

Como as negociações estão a cargo dos Ministérios de Relações Exteriores e, pelo menos no caso brasileiro, com alguma influência dos Ministérios da Fazenda e do Desenvolvimento, Indústria e Comércio, a arena decisória é praticamente limitada ao poder executivo, representado pela Presidência da República e Ministro das Relações Exteriores.

Foi exatamente nesta arena que as Centrais Sindicais dos quatro países iniciantes do Mercosul atuaram para tentar influenciar seus rumos, principalmente, no tocante aos aspectos sociais e trabalhistas. As referências para suas reivindicações provinham de resoluções adotadas nas reuniões da Coordenadora de Centrais Sindicais do Cone Sul (CCSCS), uma rede de centrais sindicais da Argentina, Bolívia, Brasil, Chile, Paraguai e Uruguai, criada em 1986, inicialmente, para fortalecer os laços sindicais de solidariedade na região e que posteriormente se dedicou intensivamente ao tema da integração regional.

Enquanto as centrais sindicais buscavam dialogar com seus respectivos governos, a Coordenadora buscava interlocução diretamente, por meio de audiências, com o CMC durante as Cúpulas Presidenciais do Mercosul que se realizam semestralmente.

As principais reivindicações eram a adoção de uma Carta Social para proteger os trabalhadores e setores sociais mais vulneráveis de eventuais efeitos negativos da integração, a criação de fundos estruturais para financiar processos de reconversão produtiva e requalificação profissional dos setores econômicos prejudicados pela competição comercial entre os países membros e, finalmente, a democratização do processo assegurando maior participação social e mais poder para os parlamentos dos quatro países.

Os resultados foram: a conquista do direito das Centrais Sindicais de participarem dos Sub Grupos de Trabalho setoriais do Mercosul, além da criação do Sub Grupo de Trabalho 10 para tratar de assuntos trabalhistas e previdenciários; a criação do Fórum Consultivo Econômico e Social (FCES) e a aprovação de uma "Declaração Sócio - Laboral 
do Mercosul" que incluiu uma série de direitos trabalhistas e sociais a serem respeitados pelas empresas e governos na região, devidamente acompanhada por uma Comissão Regional Tripartite.

Esta "Declaração" é composta por 13 artigos que contemplam as Normas Fundamentais de Trabalho da OIT, bem como direitos relacionados á saúde e segurança no trabalho, previdência social e trabalhadores migrantes. O papel da Comissão Regional Tripartite é o de analisar e se pronunciar sobre as queixas de violações do conteúdo da "Declaração".

Os atores não governamentais que buscaram incidir desde o início sobre as negociações do Mercosul foram basicamente as centrais sindicais dos quatro países, bem como as respectivas associações empresariais. Após a criação do FCES em 1995 reunindo empresários, trabalhadores e ONG's começou a haver também a participação de organizações de representação de consumidores como o Instituto de Defesa do Consumidor do Brasil (IDEC) e na mesma época foi criada a Rede Mercocidades por iniciativa de alguns prefeitos, como os de Montevidéu, Porto Alegre, Belo Horizonte, entre outros.

Foi somente a partir de 2006 que, principalmente, por incentivo dos quatro governos do Mercosul, começaram a se realizar as "Cúpulas Sociais do Mercosul" reunindo uma multiplicidade de representações sociais e sindicais do campo e da cidade, trazendo nova dinâmica para o debate da sociedade, bem como novas reivindicações.

O movimento sindical, apesar de crítico desde o início com a priorização dos aspectos comerciais; a ausência de discussões sobre políticas industriais, livre circulação de mão de obra, entre outras e a baixa institucionalidade do Mercosul, ainda assim, o considera uma oportunidade para o desenvolvimento da região no contexto da globalização e adotou uma estratégia pró-ativa quanto a sua evolução, embora esta se apresente como um processo de avanços e paralisias.

Quanto, à utilidade da "Declaração Sócio Laboral", a percepção dos sindicatos do Cone Sul do continente é semelhante à de seus colegas do movimento sindical norte americano e, pelas mesmas razões, de que ela em si mesma é pouco eficaz.

\subsection{As iniciativas para fortalecer o arranjo estatal do regime trabalhista} internacional 
Desde os anos 1960 algumas entidades sindicais com representação internacional tentaram incluir suas visões sobre desenvolvimento econômico e o respeito aos direitos trabalhistas em decisões adotadas por organizações internacionais como o Banco Mundial, o Fundo Monetário Internacional, o Acordo Geral de Comércio e Tarifas, entre outros, além de sua atuação rotineira junto à Organização Internacional do Trabalho (Kyloh; O’Neill; Whelton, 2001).

Duas razões motivavam estas iniciativas. Em primeiro lugar porque os ajustes estruturais que, particularmente, o FMI impunha como condições para conceder ou avalizar empréstimos implicavam em equilíbrio na balança de pagamentos nacionais normalmente executados com políticas recessivas e profundos cortes no custeio de políticas sociais agravando o desemprego e a pobreza nos países tomadores de empréstimos. Imaginava-se que a menção aos direitos dos trabalhadores pudesse contribuir de alguma forma para amenizar esses problemas.

A segunda razão era que as normas da OIT e seus mecanismos de cumprimento se revelavam insuficientes para lidar com a nova realidade da incorporação de países em desenvolvimento na produção internacional utilizando-se de sua mão de obra barata como vantagem comparativa, não só devido ao baixo custo de vida como também com frequiência à inexistência de legislação trabalhista nacional eficiente. Isto gerava preocupações quanto ao rebaixamento de padrões de trabalho que poderia até mesmo se estender aos países onde estes tradicionalmente eram elevados.

A preocupação com o custo do trabalho reduzido com o propósito de ampliar a competitividade esteve na origem da OIT conforme já mencionado, mas também provocou debates em outros fóruns sobre o vínculo entre comércio e direitos trabalhistas diante da percepção da incapacidade desta organização de garantir este princípio.

\subsubsection{A discussão sobre comércio e direitos trabalhistas;}

Uma das primeiras medidas conhecidas sobre a relação entre comércio e direitos trabalhistas foi a "Lei do Trabalho Infantil" do presidente Woodrow Wilson aprovado pelo Congresso nos Estados Unidos já em 1916. Esta lei proibia o comércio interestadual de 
produtos manufaturados por crianças com menos de 14 anos; de minérios extraídos por menores de 16 anos ou ainda de qualquer produto fabricado com a participação de menores de 16 que trabalhassem mais de oito horas diárias. Ela acabou sendo invalidada pela Suprema Corte do país e o Congresso então aprovou outra legislação que aplicava multas de $10 \%$ sobre o valor dos produtos feitos com a participação de crianças (Link e Catton, 1965).

O Artigo $7^{\circ}$ do Capítulo II da "Carta de Havana" dizia que "Os Estados reconhecem que a existência de condições de trabalho não eqüitativas, especialmente nos setores da produção destinados à exportação, cria dificuldades aos intercâmbios internacionais”. Esta "Carta" de 1948 constituiu a Organização Internacional de Comércio (OIC), que, no entanto, nunca entrou em vigor e foi substituída pelo GATT, cujo Artigo XX, alínea "e" proibia o comércio de bens produzidos em prisões (Martinez, 2002).

Os sistemas gerais de preferências dos EUA e da UE também incluem o respeito pelas "normas de trabalho internacionalmente reconhecidas" como uma condição para acessá-lo, embora nenhum dos dois possua mecanismos de monitoramento sobre o tema. Porém, vez ou outra e apesar da terminologia vaga, alguns países têm perdido o seu acesso ao SGP por não haver ratificado alguma convenção fundamental da OIT.

Em 1987, durante as negociações da Rodada Uruguai do GATT, o governo norte americano propôs formalmente a criação de um grupo de trabalho "que estudasse a relação entre comércio e as normas de trabalho internacionalmente reconhecidas" (Martinez, 2002). Na conferência final da rodada em 1994 em Marrakesh, o representante norteamericano, com apoio de seu colega francês, insistiu no tema ao propor que a futura organização - OMC - deveria adotar medidas para preservar padrões mínimos de trabalho para coibir a concorrência desleal no comércio mundial devido ao "dumping social".

Embora alguns países como o México e o Brasil se dispusessem a aceitar alguma proteção trabalhista nos respectivos acordos de integração regionais, a proposta dos Estados Unidos foi criticada pelos representantes destes dois e de outros países em desenvolvimento sob a alegação de que a vinculação entre direitos trabalhistas e comércio no âmbito da OMC poderia criar novos instrumentos protecionistas e que o organismo adequado para tratar de normas de trabalho era a OIT. Porém, a intervenção americana manteve 
informalmente o tema na agenda, pelo menos até a I Conferência Ministerial da OMC realizada em Cingapura dois anos depois.

A Confederação Internacional das Organizações Sindicais Livres (CIOSL) com o apoio de algumas centrais sindicais filiadas e aproveitando o discurso do representante dos EUA em Marrakesh, lançou uma campanha pela inclusão de uma "Cláusula Social na OMC”, na primeira conferência ministerial da nova organização que obrigasse seus países membros a respeitarem as normas de trabalho fundamentais da OIT.

Embora nunca fosse explicitado, o objetivo era aproveitar o poder coercitivo da OMC para obrigar todos os países a cumprirem corretamente as normas, sob o risco de sofrerem sanções comerciais.

A campanha da CIOSL iniciou-se na Conferência da OIT em junho de 1994, onde todos os representantes do grupo dos trabalhadores que usariam a palavra no plenário foram incentivados a manifestar seu apoio à cláusula social. Em seguida foi iniciado um processo de lobby junto a diversos governos, principalmente, dos países desenvolvidos. Entre eles, além do governo americano, foi conquistado certo apoio dos países escandinavos, em particular da Noruega que se tornou um advogado importante da "Cláusula Social".

No ano seguinte, foi dado outro passo por meio da inclusão da necessidade do respeito às normas fundamentais de trabalho da OIT, entre as resoluções da Conferência Social da ONU em Copenhagen (Alves, 2001).

Em 1996, a CIOSL realizou seu XVI Congresso Mundial que aprovou a realização de uma campanha mundial em defesa das normas fundamentais de trabalho incluindo a introdução de uma cláusula social na OMC.

No mesmo ano, a TUAC convenceu a OCDE a realizar um estudo sobre possíveis benefícios no comércio mundial para os países que respeitavam as normas fundamentais de trabalho seguido de uma série de seminários e "work-shops". O estudo revelou que cumprir ou não as normas, não fazia diferença para o desempenho econômico dos países analisados e os sindicatos usaram isto como argumento que, se não importava, porque então não cumpri-las?

O "lobby" sindical foi feito também com os governos de alguns países em desenvolvimento na América Latina, África e Ásia. O único que se dispôs a apoiar a proposta foi o governo da África do Sul que buscava mecanismos de proteção contra a 
"invasão" de produtos têxteis extremamente baratos vindos de seus países vizinhos e que competiam com a produção local. Porém, este governo sugeriu que a reivindicação deveria mudar para algo mais palatável para quebrar a forte resistência dos países opositores.

Ressuscitou então a sugestão da criação de um grupo de trabalho ${ }^{14}$ no âmbito da OMC, que em cooperação com a OIT, pudesse analisar o assunto e formular propostas. A mudança de tática não ajudou muito. A ampla maioria dos países membros da OMC se opunha à proposta e tampouco havia consenso no próprio meio sindical. Nem todas as centrais dos países em desenvolvimento filiadas à CIOSL estavam de acordo, preocupadas com eventuais usos protecionistas da medida, e menos ainda as organizações independentes ou as filiadas a Federação Sindical Mundial (FSM) e a Confederação Mundial do Trabalho (CMT). Também não havia consenso entre várias ONGs que acompanhavam as negociações de liberalização comercial.

De todo modo, o assunto polarizou a primeira conferência ministerial da OMC em Cingapura. Havia um pequeno grupo de países que apoiavam a instalação do grupo de trabalho e outro que radicalizou a posição que "trabalho" jamais deveria ser assunto de pauta da OMC, convencendo, inclusive, o governo anfitrião de Cingapura e que presidiria a conferência, a desconvidar o Diretor Geral da OIT, Michel Hansenne a participar.

No final prevaleceu uma resolução que sepultou o assunto e que se tornou o Parágrafo 4 da Declaração da I Conferência Ministerial da OMC:

Renovamos nosso compromisso de respeitar as normas fundamentais de trabalho internacionalmente reconhecidas. A Organização Internacional do Trabalho (OIT) é o órgão competente para estabelecer estas normas e ocupar-se delas, e afirmamos nosso apoio ao seu trabalho de promoção das mesmas. Consideramos que o crescimento e desenvolvimento econômico impulsionados pelo crescimento do comércio e da maior liberalização comercial contribuirão para a promoção destas normas. Rechaçamos a utilização destas normas com fins protecionistas e convimos que não se deve, em absoluto, questionar as vantagens comparativas, particularmente, dos países em desenvolvimento com baixos salários. A este respeito tomamos nota que as secretarias da OMC e OIT prosseguirão com sua atual cooperação $(\mathrm{OMC})$.

Alguns sindicalistas, mais otimistas, avaliaram que a Resolução de Cingapura não era de toda má, pois ao afirmar que "as secretarias da OMC e OIT prosseguirão com sua atual

\footnotetext{
${ }^{14}$ A criação de grupos de trabalho para analisar temas sobre os quais não havia ainda um mínimo de consenso era usual no GATT e foi utilizado para discutir a relação entre comércio e investimentos, comércio e meio ambiente, entre outros.
} 
cooperação" estaria indicando que os vínculos entre as regras de comércio coordenadas pela OMC e as normas de trabalho promovidas pela OIT haviam sido reconhecidos pela Conferência de forma que eventualmente se poderia pensar em promover alguma atividade conjunta daí em diante.

No entanto, nunca mais houve qualquer discussão no âmbito da OMC sobre este assunto. A III Conferência Ministerial da OMC realizada em 1999 em Seattle nos EUA não conseguiu aprovar sequer o início de uma nova rodada de negociações comerciais. Uma entrevista dada pelo Presidente dos Estados Unidos, Bill Clinton, durante a conferência propondo a aplicação de sanções comerciais contra os países onde existia trabalho infantil aumentou a espécie sobre o tema.

A única medida adotada quanto à resolução de 1996 sobre o "prosseguimento" da cooperação ente OMC e OIT foi a realização de uma publicação conjunta 11 anos depois denominada "Comércio e emprego: os desafios da investigação sobre políticas, um estudo conjunto OIT/OMC" sobre trabalhos acadêmicos relacionados ao tema.

Ainda assim, apesar da oposição da maioria dos países membros da OMC, mesmo à criação do Grupo de Trabalho na OMC e as divergências no interior do movimento sindical e social sobre a proposta, foi chamada a atenção para a contumaz violação de direitos humanos e trabalhistas na competição mundial no comércio e o debate que ocorreu mundialmente contribuiu para colocar o tema dos padrões trabalhistas na agenda em outras negociações e instituições internacionais.

\subsubsection{As iniciativas para fortalecer a OIT}

A iniciativa de propor o envolvimento de outras instituições internacionais para reforçar a governança do regime trabalhista usualmente administrado pela OIT, sob o argumento da sua falta de poder coercitivo, também provocou a discussão sobre a necessidade de fortalecer o papel desta organização, embora sempre sob a ótica Estadocentrada.

Deste modo adotaram-se várias medidas no âmbito da OIT, entre elas:

- uma campanha para ampliar o número de ratificações nacionais das convenções que compõem as normas fundamentais de trabalho;

- a aprovação da Convenção 182 que abole as piores formas de trabalho infantil; 
- a "Declaração Tripartite de Princípios sobre Empresas Multinacionais e Política Social da OIT" foi revista e ampliada;

- aprovou-se a "Declaração de Princípios e Normas Fundamentais no Trabalho";

- instalou-se um grupo de trabalho Ad Hoc para analisar a "Dimensão Social da Globalização";

- uma campanha mundial pela implantação de uma agenda de "Trabalho Decente".

Especificamente em relação às EMNs havia sido aprovada a "Declaração Tripartite de Princípios sobre Empresas Multinacionais e Política Social da OIT” em 1977, que foi revista e ampliada em 2000. Ela fora uma resposta às reivindicações de governos de países em desenvolvimento e sindicatos que sentiam a necessidade de regulamentar internacionalmente a conduta das empresas multinacionais e a relação delas com os países onde se instalavam (IOS, 2004). Inclusive estavam se estabelecendo zonas francas de exportação em vários deles e havia uma preocupação com a ausência geral de regras (Scherrer e Greven, 2001).

A "Declaração" possui oito partes que tratam de promoção do emprego, segurança no emprego, formação profissional, condições de trabalho e de vida, segurança e higiene no trabalho, sistema de consultas, exame de reclamações e mecanismo de solução de conflitos.

Em 1998, a direção da OIT lançou uma campanha para ampliar a quantidade de ratificações das Normas Fundamentais de Trabalho. Por exemplo, a Convenção 138 que determina a idade mínima para o trabalho, havia sido aprovada em 1973, mas 25 anos depois, menos da metade dos países membros a haviam ratificado. Esta campanha foi bem sucedida e o número de ratificações das normas fundamentais ampliou-se significativamente. O Brasil, por exemplo, ratificou a Convenção 138 nesta época e definiu a idade de 16 anos como a mínima para o trabalho, permitindo o trabalho a partir dos 14 anos apenas sob a forma de aprendizagem.

O Conselho de Administração da OIT aprovou neste mesmo ano, a "Declaração de Princípios e Direitos Fundamentais no Trabalho" que reforçava a importância das convenções e recomendações fundamentais cujo conteúdo é considerado normativo para todos os países membros, independentemente das ratificações individuais das Normas Fundamentais no Trabalho. 
Foi nomeada também uma comissão de especialistas da organização para produzir relatórios anuais de avaliação global sobre o grau de cumprimento e progresso de cada uma delas consecutivamente. Estes relatórios ao serem discutidos e aprovados nas conferências anuais da OIT permitem avaliar o progresso feito, não apenas globalmente, mas também em cada país individualmente.

O passo seguinte foi a criação de uma Comissão sobre a "Dimensão Social da Globalização". Ela foi proposta pela OIT com a participação de uma série de personalidades notáveis ${ }^{15}$ e seu funcionamento foi financiado pela organização. Entretanto, a comissão tinha autonomia e seus trabalhos foram co-dirigidos pelos presidentes da Finlândia e Tanzânia. O relatório de seu trabalho foi depois aprovado pelo Conselho de Administração da OIT e quanto ao fortalecimento do cumprimento das normas fundamentais de trabalho apresentou as seguintes propostas:

- As instituições internacionais pertinentes devem assumir suas responsabilidades na promoção da "Declaração de Princípios e Direitos Fundamentais" da OIT e assegurar que nenhuma de suas políticas ou programas impeça a sua aplicação.

- Se as causas das violações se devem mais à falta de capacidade do que de vontade política, devem ser implementados programas de assistência técnica.

- Devem ser aumentados os recursos da OIT para reforçar sua capacidade supervisora e de controle da aplicação das normas.

- Aplicação do Artigo 33 da Constituição da OIT em caso de violações contumazes das convenções fundamentais.

- Apoio da OIT às iniciativas das empresas de adoção de códigos de conduta, responsabilidade social empresarial, entre outras (OIT, 2009a).

Por fim, em 2003 foi dado início à implantação da chamada Agenda de Trabalho Decente onde esta qualificação de trabalho era definida como um "trabalho produtivo adequadamente remunerado, exercido em condições de liberdade, eqüidade e segurança, sem quaisquer formas de discriminação e capaz de garantir uma vida digna a todas as pessoas que vivem de seu trabalho" (OIT, 2009b).

Esta definição incorpora cinco eixos que são o emprego de qualidade, extensão de proteção social a todos, promoção do diálogo social, respeito ás normas fundamentais de

\footnotetext{
${ }^{15}$ A professora Ruth Cardoso era a única participante do Brasil.
} 
trabalho e o trabalho exercido sob condições de segurança - não apenas quanto á integridade física, mas também quanto ao aspecto psicológico de o trabalhador não ser demitido sem motivo, assediado moralmente, entre outras medidas arbitrárias.

O aspecto prático desta agenda é o compromisso firmado pelos países membros da OIT de estabelecer agendas nacionais para promoção do "Trabalho Decente" sobre as quais prestarão contas periodicamente a partir de indicadores de maior ou menor déficit de trabalho decente.

Estas iniciativas são contemporâneas e vigentes com o intuito de dinamizar o papel da OIT e obedecem a lógica "Estado-centrada", mas também oferecem algumas agendas que o movimento social e sindical em tese poderiam agarrar para mobilizar seus constituintes e desencadear campanhas para fortalecer o regime trabalhista.

\subsection{O regime trabalhista internacional e seu arranjo privado;}

A modificação na divisão internacional do trabalho inerente à evolução do capitalismo estabeleceu diferentes resultados econômicos e sociais, mas percebe-se que a regulação empresarial que a acompanha adota padrões praticamente iguais em todo o mundo, em prazo relativamente curto, independentemente do papel que eventualmente caiba a cada nação nesta divisão.

Isto se torna evidente, por exemplo, a partir do desenvolvimento das ferrovias em 1840, da segunda revolução industrial em 1890, da "Era do Jato" em 1950 e da "Era da Informação" em 2000. As respectivas regulações empresariais adotaram certos procedimentos a partir do início de cada inovação tecnológica e produtiva que uma vez testados pelas empresas líderes, rapidamente se padronizaram mundialmente e extrapolaram o marco meramente empresarial.

Foi assim com os paradigmas produtivos como o Taylorismo, o Fordismo, a terceirização e flexibilidade, bem como quanto a aspectos trabalhistas e sociais que implicaram no reconhecimento de certos direitos, mesmo que freqüentemente violados, como o trabalho livre, jornada máxima de trabalho, descanso semanal, negociação coletiva, proteção social, entre outros e mais recentemente a chamada Responsabilidade Social Empresarial (RSE) e outros arranjos privados que visam estabelecer padrões básicos de ética empresarial. 
Os arranjos privados evoluíram sobremaneira a partir da década de 1980 quando, sob a predominância do pensamento neoliberal, as empresas preferiam a adoção de iniciativas voluntárias e procedimentos auto-regulados invés de regras introduzidas pelo Estado (Clapp; Utting, 2008). Quando muito elas adotaram algumas referências dos arranjos trabalhistas Estado-centrados como as normas fundamentais de trabalho, padrões ambientais, direitos humanos, entre outros.

A iniciativa privada assumiu uma agenda ampla sob o termo responsabilidade social empresarial envolvendo temas como direitos trabalhistas, padrões ambientais, coibição de corrupção, parcerias público-privado, monitoramento, certificações e outros. Em alguns casos as empresas discutem o conteúdo da agenda com organizações sindicais ou com outras partes interessadas ${ }^{16}$ para definir as políticas, mas na maioria das vezes adotam-nas unilateralmente.

O arranjo privado, todavia, ainda é um processo em formação e sua cobertura freqüentemente é mais restrita que o regime trabalhista internacional Estado-centrado, mas em vários casos tem se demonstrado mais eficaz por implicar em convencimento e aceitação dos atores envolvidos, principalmente, no caso das empresas que vêem alguma vantagem em adotá-las.

Diante disso comecemos por comentar a RSE e depois mencionar algumas das agendas mais relevantes.

\subsubsection{Responsabilidade Social Empresarial (RSE)}

Não existe um conceito universalmente aceito sobre o que venha a ser RSE e como geri-la, mas há uma série de parâmetros quanto ao conteúdo e funcionamento, aceitos de forma razoavelmente consensuais.

A idéia que norteia a RSE é que uma empresa não deve ser responsável somente perante seus acionistas, mas também diante da sociedade em seu sentido mais amplo ou

\footnotetext{
${ }^{16}$ As partes interessadas no caso de uma empresa podem ser acionistas, clientes, empregados, fornecedores, comunidades, governos e até futuras gerações quando o tema é ambiental (IOS, 2004: 20).
} 
perante suas partes interessadas ("stakeholders") que podem ter preocupações sociais, ambientais e humanas específicas (Freeman e Morgera apud Clapp e Utting, 2008).

Porém, segundo Archie B. Carrol citado pela Revista do Observatório Social há pelo menos quatro entendimentos sobre o que seria responsabilidade social de empresas e que podem inclusive ser combinadas:

- a principal função das empresas é produzir bens e serviços demandados pela sociedade e vendê-los com lucro;

- as empresas devem exercer sua atividade produtiva respeitando a legislação vigente;

- a sociedade espera que as empresas sigam comportamento e normas éticas;

- o papel social das empresas é filantrópico assumido voluntariamente e sem clara expectativa da sociedade. As ações são realizadas por escolha individual dos administradores que definem onde investir tempo, dinheiro e talento; (2004).

A preferência do movimento sindical é pela adoção de uma política de RSE pelas empresas que vá além de simplesmente cumprir a lei, ser eficiente e praticar filantropia, até porque os dois primeiros itens são obrigações e não meras atitudes responsáveis.

A sua expectativa é a geração de uma cultura empresarial com caráter internacional que também incorpore o regime trabalhista internacional às suas práticas e que envolva as partes interessadas no acompanhamento delas.

Este tipo de abordagem implicaria na superação da noção de RSE centrada em esquemas voluntários e auto-regulados para incluir maior aceitação de regulação legal e vinculante, maior confiança em políticas públicas para promover voluntariado e aceitação de governança multi-dimensional, multi-stakeholder e multi-escalar para assegurar controle social sobre atividades corporativas e mercados (Clapp e Utting, 2008). 
Entretanto, isto tem sido mais aceito no tocante à responsabilidade empresarial e desenvolvimento ambientalmente sustentável do que em relação ao regime trabalhista internacional. De acordo com pesquisa realizada por Clapp e Utting em 2007 a adesão das EMNs a esquemas de RSE ainda é limitada considerando o universo de 79.000 empresas e suas 790.000 subsidiárias ${ }^{17}$, além de milhões de fornecedores. Eles identificaram aproximadamente 138.000 iniciativas multi-stakeholder das quais 130.000 se relacionam a iniciativas ambientais e 8.000 a combinações entre regimes de meio ambiente, direitos humanos e trabalho (2008).

Estas iniciativas estão contidas em instituições como a ISO, a SA e o Pacto Global da ONU que serão comentadas mais adiante e outros esquemas como "Forest Stewardship Council" (FSC) que certifica o manejo sustentável de florestas; o "Global Reporting Initiative" (GRI) que orienta a publicação de relatórios de balanço social de empresas; a "Fair Labor Association" e "Fair Wear Foundation" que focam em condições de trabalho e direitos trabalhistas no setor de vestuário; Fundos de Investimento Éticos que somente investem em ações de empresas que cumprem determinados critérios de direitos humanos, trabalhistas, ambientais, entre outros; além das "Diretrizes para EMNs da OCDE” e outras.

\subsubsection{A ISO 26.000;}

A ISO é uma organização não governamental fundada em 1947 com sede em Genebra na Suíça e atualmente formada a partir de 157 institutos nacionais, públicos ou privados, encarregados de definir normas técnicas padrão nos seus respectivos países. No caso do Brasil o membro da ISO é a Associação Brasileira de Normas Técnicas (ABNT), uma entidade privada.

Seu mandato é elaborar normas ("Standards") para a produção e procedimentos técnicos em setores díspares como a produção industrial, agricultura, construção,

\footnotetext{
${ }^{17}$ Ver página 36 da dissertação.
} 
engenharia, equipamentos médicos, desenvolvimento da tecnologia da informação, entre outros.

O entendimento que motiva a organização é que a padronização de normas técnicas em nível internacional oferece ganhos de escala na produção e maior qualidade dos produtos. A ISO elabora as normas de acordo com a demanda do mercado e a aplicação delas é voluntária e já elaborou aproximadamente 17.000 delas desde sua fundação. Porém, não se responsabiliza pela sua certificação e nem pela auditoria ou pelo monitoramento de seu cumprimento. Para isto há instituições locais. No Brasil é o INMETRO.

Mais recentemente atuou na padronização de normas relativas à gestão administrativa - ISO 9.000, gestão de meio ambiente interno e saúde ocupacional - ISO 13.000 e gestão ambiental ISO 14.000. Atualmente está concluindo uma padronização sobre Responsabilidade Social Empresarial (RSE) por meio da ISO 26.000 que deverá ser publicada e entrar em vigor em 2010.

Porém, ao contrário das demais normas ISO, a 26.000 não será certificável e representará na prática um guia internacional sobre RSE e uma referência para analisar e comparar a política de empresas que declarem adotar esquemas de responsabilidade social.

O seu conteúdo trata de meio ambiente, democracia, cooperação social e solidariedade (filantropia), participação das partes interessadas, transparência e envolvimento da cadeia produtiva. Foi assinado um memorando de entendimento entre a ISO e a OIT para assegurar sua compatibilidade com as convenções desta última, principalmente, em relação às normas fundamentais de trabalho.

\subsubsection{O SA 8.000}

Este é um padrão internacional proposto em 1997 pela SAI, uma ONG inglesa, que permite emitir certificados quanto ao comportamento social de empresas

Ela é voltada para orientar a gestão empresarial a partir do sistema de auditoria da ISO 9.000, inspirada nos princípios de convenções internacionais de direitos humanos para promover melhores condições de trabalho (SAI, 2009a).

A SA 8.000 é passível de certificação, auditoria e verificação por terceiros. Ela aborda nove requisitos de responsabilidade social que são as cinco normas fundamentais de 
trabalho da OIT, a proibição de assédio moral como prática disciplinar, jornada semanal máxima de trabalho, remuneração e sistema de gestão (IOS, 2004).

Uma empresa para ser certificada necessita cumprir com todos os requisitos da SA 8.000, respeitar a legislação nacional e normas internacionais relacionados a eles, divulgar amplamente sua política de RSE, realizar avaliações periódicas sobre esta política, nomear um representante da alta administração da empresa como responsável pela gestão dela, controlar que seus fornecedores também respeitem os requisitos da SA 8.000 e disponibilizar as informações referentes à aplicação dela e também para verificações externas (IOS, 2004).

De acordo com o relatório de 2008, a SAI já havia emitido 1.835 certificações SA 8.000 até então para 67 atividades industriais diferentes em 68 países e beneficiando 985.847 trabalhadores (SAI, 2009b).

A SA 8.000 é provavelmente a instituição privada mais incisiva quanto a governança do regime internacional de trabalho embora quantitativamente suas certificações sejam limitadas.

\subsubsection{Os códigos de conduta e os Acordos Marco Globais;}

Estas são duas iniciativas contraditórias porque normalmente os códigos de condutas relacionados ao regime de trabalho são adotados unilateralmente por empresas e freqüentemente visam dispensar a presença do sindicato como intermediário e negociador das relações de trabalho entre a empresa e seus empregados, enquanto os Acordos Marco Globais são negociados entre EMNs e Federações Sindicais Internacionais que representam trabalhadores de diferentes ramos econômicos, internacionalmente.

Os códigos de condutas voluntários sofrem várias críticas porque normalmente não incluem as normas fundamentais de trabalho no seu conteúdo, não são negociados com o respectivo sindicato, não utilizam as definições e formulações das autoridades competentes 
como a OIT, não estabelecem mecanismos de acompanhamento, não cobrem os trabalhadores terceirizados e subcontratados, não são transparentes, entre outros motivos.

Vejamos o que diz o "Código de Ética" da empresa americana Caterpillar: "Esperamos conduzir nosso negócio de tal forma que os empregados não sintam a necessidade de representação por sindicatos ou terceiros [...]" (IOS, 2004: 74).

Já os Acordos Marco Globais começaram a ser negociados em 1995 entre EMNs e as respectivas Federações Sindicais Internacionais. Normalmente visam promover o respeito pelas Normas Fundamentais de Trabalho da OIT nestas empresas em qualquer parte do mundo e podem ou não incluir mecanismos de monitoramento.

Há quase 200 deles assinados até o momento com empresas multinacionais originários de quase 20 países, europeus em sua maioria, e que atuam em dezenas de setores da indústria, serviços e agricultura.

A sua eficácia, como será discutido mais adiante, está relacionada à maneira como os AMGs são negociados, se eles possuem mecanismos de monitoramento e se os sindicatos de base das respectivas Federações Sindicais Internacionais têm conhecimento de seu conteúdo e capacidade de utilizá-los em seu mandato sindical.

\subsection{Uma situação especial: o Pacto Global da ONU}

O "Global Compact" ou "Pacto Global" da ONU difere em algum grau dos demais arranjos, pois não foi negociado com ninguém, mas acabou se tornando uma iniciativa que chamou certa atenção. A sua proposta foi anunciada pelo Secretário Geral da ONU, Kofi Annan durante o Fórum Econômico Mundial de Davos em janeiro de 1999, como parte do pacote das iniciativas que seriam apresentadas naquele ano na transição para o novo século e milênio. 
O "Pacto" não tem uma estrutura de coordenação e nem de acompanhamento do seu cumprimento. É uma plataforma de promoção de práticas empresariais consideradas positivas (IOS, 2004). Possui dez princípios baseados na Declaração Universal de Direitos Humanos da ONU, nos Direitos Fundamentais no Trabalho da OIT, na Declaração do Rio sobre Meio Ambiente e Desenvolvimento da ONU e no Pacto Anticorrupção das ONU. Estes princípios são os seguintes:

1) Apoiar e respeitar a proteção aos direitos humanos dentro de sua esfera de influência;

2) Assegurar que suas corporações não sejam cúmplices de abusos contra os direitos humanos;

3) Garantir a liberdade de associação e reconhecimento do direito da negociação coletiva;

4) Eliminar todas as formas de trabalho forçado e compulsório;

5) Eliminar efetivamente o trabalho infantil;

6) Eliminar a discriminação em relação ao emprego e ocupação;

7) Apoiar uma abordagem preventiva aos desafios ambientais;

8) Adotar iniciativas promotoras de maior responsabilidade ambiental;

9) Encorajar o desenvolvimento e a difusão de tecnologias ambientais limpas;

10) Abster-se de favorecer autoridades públicas com fins de benefícios empresariais (IOS, 2004);

Para aderir, as empresas devem assumir três compromissos básicos:

- Assumir um compromisso público de promover os princípios e objetivos do "Global Compact";

- Publicar pelo menos um exemplo concreto de suas "melhores práticas" anualmente na página Web da ONU;

- Associar-se a uma organização especializada da ONU com a finalidade de promover projetos em parceria (IOS, 2004);

Portanto, ele representa um arranjo especial, pois nasce de uma iniciativa estatal supra-nacional, a ONU, sem que fosse demandado pelos Estados Nacionais ou pelos atores sociais, fossem empresas ou sindicatos e mesmo a própria ONU sequer toma nota se as empresas que aderiram ao Pacto Global cumprem com os requerimentos básicos acima.

A própria Sub-Comissão da ONU para Promoção e Proteção dos Direitos Humanos aprovou em 2003 um documento intitulado "Normas da ONU sobre Responsabilidades das Corporações Transnacionais e outras Empresas quanto a Direitos Humanos" que resume 23 
normas pinçadas do sistema de direitos humanos da ONU, da OIT e de alguns pactos ambientais (Rathgeber, 2006).

No entanto, esta resolução que possui mecanismos de monitoramento e a possibilidade de sanções financeiras, por intermédio de indenizações aos prejudicados, ainda não foi adotada pelo Conselho de Direitos Humanos da Organização e encontra-se em debate.

\section{AS RELAÇÕES TRANSNACIONAIS E OS ATORES SOCIAIS}

\subsection{Introdução}

A utilização prática dos arranjos descritos no capítulo anterior pressupõe a existência de mecanismos que possibilitem às diferentes organizações sociais e sindicais, organizações não-governamentais, empresas, governos, organizações internacionais e outras interagirem de acordo com seus interesses através das fronteiras dos Estados Nacionais.

Além das empresas, cuja atuação e papel foram desenvolvidos no primeiro capítulo, cabe identificar também três outros atores sociais que buscam participação na governança global:- os sindicatos, as organizações sociais e as organizações não-governamentais (ONGs). Os três fazem parte do movimento social lato sensu, mas devido a algumas características particulares e pela importância política que cada um demonstrou em determinados momentos históricos, é mais adequado começar por conceituá-los individualmente.

Os sindicatos são associações de trabalhadores que historicamente surgiram com a formação das empresas ainda durante a "primeira revolução industrial", embora sua 
existência tenha se consolidado a partir da "segunda" nas últimas décadas do século XIX quando, inclusive, começaram a obter reconhecimento legal como entidades de representação de classe ${ }^{18}$. Eles representam um tipo de associação que Leonardo Avritzer classificou de "conflitiva com o campo sistêmico e que se institucionalizou num campo prédefinido de ação" (apud Vieira, 2001) porque defendem direitos e interesses de trabalhadores perante empresas e o Estado e as ações desenvolvidas para exercer essa defesa nem sempre são pacíficas ao implicarem na utilização de táticas como greves, mobilizações, ações judiciais, entre outras. Os primeiros trabalhadores a organizarem sindicatos e obter seu reconhecimento perante o Estado e empresas foram os da indústria e serviços, enquanto, os trabalhadores na agricultura e serviços públicos, na maioria dos países, quase sempre conquistaram esse direito muito tempo depois.

Estruturalmente, os sindicatos exercem representações por empresa, por ramo de atividade econômica, por categoria profissional ou por profissão. A diferença entre o terceiro e o quarto modelos é que todos trabalhadores de uma firma serão considerados de uma determinada categoria profissional a partir da atividade produtiva desta empresa. Por exemplo, quem trabalha numa indústria metalúrgica é da categoria dos metalúrgicos, quem trabalha no comércio é comerciário e assim por diante, sem distinguir se o trabalhador é escriturário, pintor, eletricista ou de outra profissão, cujas uniões de trabalhadores da mesma profissão, independentemente de onde trabalham, representariam o último modelo mencionado.

Há países onde existe mais de um sindicato da mesma natureza de representação num mesmo local de trabalho, o que é conhecido como pluralismo sindical e outros onde se admite apenas um, que é o modelo de unicidade sindical. Independentemente dessa escolha,

\footnotetext{
${ }^{18}$ Ver página 22 da dissertação.
} 
os sindicatos de base normalmente se juntam em estruturas verticais da mesma empresa, ramo de atividade econômica, categoria ou profissão que são as federações regionais ou nacionais e nas horizontais que são as centrais sindicais. $\mathrm{O}$ direito de o trabalhador se organizar e ser representado por um sindicato está assegurado internacionalmente nas Convenções 87 e 98 da OIT.

A concepção do papel dos sindicatos e sua definição ideológica evoluíram das associações criadas para o socorro mútuo entre os trabalhadores por razões de doenças, falecimentos ou outras questões sociais desatendidas no início da industrialização, para sua transformação em instrumentos de defesa de direitos e interesses da classe trabalhadora, inclusive de forma "conflitiva". Esta segunda concepção gerou duas vertentes de sindicalismo classista ainda no século XIX:

- o anarquismo cujos representantes eram partidários da ação direta contra as empresas por meio de greves e até atentados contra suas instalações e que rejeitavam a idéia da sociedade organizada pelo Estado, um ente que consideravam opressor. Esta vertente declinou a partir das primeiras décadas do século XX.

- o socialismo originário do marxismo que combinava a luta pelos direitos imediatos dos trabalhadores com a proposta de disputar o poder político no estado nacional, uma concepção que representou no final do Século XIX o que Hobsbawn chamou de "novo sindicalismo" (1987). Este modelo ideológico foi o que mais se desenvolveu e atualmente é conhecido como "sindicalismo sócio-político" por representar os interesses dos trabalhadores na definição das relações de trabalho com as empresas em combinação com a busca de influência sobre o Estado e as políticas públicas.

As organizações sociais como as associações de pequenos agricultores, comunitárias, estudantes entre outras guardam muitas semelhanças com os sindicatos, embora nem todas 
as organizações sejam igualmente conflitivas com o campo sistêmico como é o caso das associações recreativas, religiosas e outras que não transformam os problemas sociais em temas de atuação.

Atualmente, registra-se a ascensão política de setores sociais que não têm a mesma tradição organizativa e, muito menos, institucional que o movimento sindical e outras associações semelhantes, como o associativismo de mulheres, camponeses sem-terra, indígenas, imigrantes e outros, bem como militantes da causa dos direitos humanos, do meio ambiente, das opções sexuais livres, etc. Contudo, estes atores sociais têm conseguido colocar uma série de temas na agenda do Estado e do mercado (Avritzer apud Vieira, 2001), mas freqüentemente são confundidos com as ONGs, pois muitas destas se envolvem com as mesmas causas.

O termo "Non-Governmental Organization (NGO) ou Organização NãoGovernamental (ONG) foi utilizado formalmente pela primeira vez por uma resolução do Conselho Econômico e Social da ONU (ECOSOC na sigla em inglês) em 1950 para se referir a organizações supranacionais e internacionais, definindo-as como "qualquer organização que não seja estabelecida por uma entidade governamental ou por um acordo intergovernamental" (Menescal, 1996). Para a Associação Brasileira de ONGs (ABONG), formalmente uma ONG "é constituída pela vontade autônoma de mulheres e homens que se reúnem com a finalidade de promover objetivos comuns de forma não-lucrativa" (ABONG, 2009). Costuma-se atribuir os seguintes atributos às ONGs, inclusive para viabilizar seu reconhecimento legal nos Estados Nacionais:

- determinado grau de organização e institucionalização formalizada;

- são de caráter privado e autônomo, situando-se entre o aparato do Estado e o mercado, muitas vezes servindo de intermediárias entre indivíduos ou grupos e o Estado; 
- guiam-se pelos seus próprios regulamentos e normas internas e somente sofrerão eventuais controles financeiros e jurídicos quanto ao manejo de recursos públicos;

- não têm fins lucrativos e a participação ou filiação é voluntária (IRELA, 1999);

Portanto, há várias definições de ONG, mas o conceito de que qualquer organização de natureza não-estatal é uma ONG, praticamente inclui qualquer organização nesse rol independentemente de seus objetivos e papéis. Embora a maioria atue de acordo com as premissas do "novo associativismo" há ONGs que foram criadas para defender causas conservadoras como as que militam contra o direito ao aborto ou empresariais como algumas que foram criadas no Brasil nos anos 1990, por exemplo, para apoiar o programa local de privatização.

Por isso, a definição de Herbert de Souza, o "Betinho" que presidiu o Instituto Brasileiro de Análises Sócio-Econômicas (IBASE), por sua vez uma ONG, ajuda a compatibilizar a definição formal desta organização com seu caráter político de atuação no campo da transformação da realidade:-

[...] uma ONG se define por sua vocação política, por sua positividade política: uma entidade sem fins de lucro cujo objetivo fundamental é desenvolver uma sociedade democrática, isto é, uma sociedade fundada nos valores da democracia - liberdade, igualdade, diversidade, participação e solidariedade. [...] as ONGs são comitês da cidadania e surgiram para ajudar a construir a sociedade democrática com que todos sonham (ABONG, 2009).

No entanto, mesmo antes de se elaborar conceitos e definir denominações já existiam organizações não-governamentais internacionais (ONGI) desde o século XIX e a mais conhecida dentre elas talvez seja a Cruz Vermelha, uma organização humanitária que desde o princípio atuou em vários países buscando amenizar o sofrimento causado pelas guerras e em pouco tempo se tornou mundialmente reconhecida e institucionalizada. 
De um modo geral pode-se dizer que na medida em que as organizações internacionais eram criadas, se estabeleceram também diferentes grupos de interesse e ONGIs para tentar influenciar as suas políticas ou beneficiar-se delas. No caso da OIT, por exemplo, seus dois constituintes sociais formais, trabalhadores e empresários, tiveram que buscar mecanismos para se articular internacionalmente com seus respectivos pares de modo a apresentarem vozes únicas nas conferências anuais e outras atividades promovidas pela organização.

Thomas Risse menciona a existência de, em média, quase cinco ONGIs por organização internacional existente, já em 1909, número que passou para sete a nove entre 1950 e 1970, sendo que em 1988 a ONU contabilizava 4.518 ONGIs atuando junto às 309 organizações internacionais existentes naquele momento, portanto, uma relação de 14 ONGIs para cada OI (1995: 11).

A quantidade de atores não-estatais atuando de algum modo no cenário internacional cresceu na segunda metade do século XX e alcançaram certos níveis de reconhecimento e participação no sistema ONU. Também começaram a obter alguns resultados políticos de sua atuação como, por exemplo, a implementação do boicote político e econômico mundial contra a África do Sul na segunda metade dos anos $1970^{19}$, devido à política de discriminação racial (“Apartheid”) vigente naquele país. Isso coincidiu com a ascensão do ideário neoliberal cujos mentores valorizavam a economia de mercado e consideravam excessiva a interferência do Estado na economia e na regulação social. Estes

\footnotetext{
${ }^{19}$ A Assembléia Geral da ONU já havia aprovado o rompimento de relações com a África do Sul após o massacre de dezenas de pessoas que protestavam contra o regime na cidade de Sharpeville em 1960, mas isso não se efetivou realmente. Porém, quando houve um novo massacre vitimando estudantes secundaristas em Soweto em 1976, a pressão do movimento social em nível internacional viabilizou o boicote.
} 
fatores contribuíram para o desenvolvimento de novas formulações teóricas sobre relações internacionais.

\subsection{As relações transnacionais}

Os primeiros autores a admitirem que as sociedades possam influenciar as organizações internacionais, não somente por intermédio dos Estados Nacionais e suas relações transgovernamentais, mas também por meio das organizações não-governamentais internacionais, foram Robert Keohane e Joseph Nye. Para eles, as instituições não-estatais defendem interesses comuns e ao possuírem políticas externas próprias e independentes dos seus respectivos Estados Nacionais desenvolvem relações internacionais que são chamadas de relações transnacionais. Estas podem afetar as relações internacionais de várias maneiras ao mudar percepções e atitudes; ao ampliar dependência, interdependência e capacidade de influência dos Estados e favorecer a emergência de atores autônomos (1971).

Tarrow considera esta análise insuficiente, pois em sua opinião a visão de Keohane e Nye considerava "um eixo inteiramente horizontal onde os atores não-estatais possuíam relações um com o outro em paralelo às relações interestatais" e também porque eles se concentravam principalmente na emergência das empresas multinacionais. No entanto, ele reconhece a importância desta primeira abordagem ao tema que possibilitou o desenvolvimento posterior de visões mais pluralistas (2005).

Risse, por sua vez, apresentou a definição de relações transnacionais de maneira sucinta e ao mesmo tempo aberta como "interações regulares através de fronteiras nacionais quando, pelo menos, um dos atores é um agente não-estatal ou que não opera em nome de um governo nacional ou de uma organização intergovernamental" (1995).

Porém, o espectro destes atores não-estatais é amplo e nem todos se posicionam do lado da ética, das boas intenções e da transformação positiva da realidade, pois traficantes de drogas, terroristas e outros do gênero, também desenvolvem relações transnacionais assim como as associações não-conflitivas. No entanto, vamos nos ater às EMNs e aos 
atores que tentam modificar a realidade em busca do bem comum, por meio da interação mútua e de mecanismos de influência sobre a governança dos diferentes regimes, particularmente daqueles que os afetam diretamente. Os arranjos que buscam influenciar para além do Estado Nacional, podem até se transformar em governança transnacional se os atores não-estatais de fato conquistarem participação nas suas instâncias de direção (Risse, 2004).

Os principais atores não-estatais que são afetados diretamente pelo regime trabalhista internacional são as empresas e os trabalhadores. Embora, em tese, uma empresa nacional e um sindicato local também possam participar do ativismo transnacional, o usual é que as empresas multinacionais e organizações sindicais internacionais se façam mais presentes, uma vez que já possuem caráter internacional.

Contudo, há movimentos sociais e ONGs que também têm interesse no funcionamento mais eficaz do regime trabalhista internacional. Por exemplo, a luta pela igualdade de oportunidades entre os gêneros no mercado de trabalho é parte da causa do movimento feminista e de ONGs que atuam nesta área, assim como há diversas organizações sociais e ONGs que combatem o trabalho infantil e escravo como parte da agenda de defesa dos direitos humanos.

Porém, o quadro desse ativismo transnacional apresenta várias características que valem a pena mencionar, inclusive, algumas que são contraditórias. Antes de nada, é preciso ter claro que quando os atores não-estatais apresentam questões que transcendem as fronteiras o fazem a partir de sua realidade nacional e se utilizam dos recursos, redes e oportunidades que suas sociedades oferecem e, assim, conectam o local com o global (Tarrow, 2005: 2). Porém, diante dos desafios colocados para o movimento social em geral pela globalização neoliberal, surgiram posições diferenciadas quanto ao caráter desta 
conexão. Por um lado há argumentos de que a globalização está impulsionando a criação de um Estado global e esta tendência deveria ser apoiada e, por outro, argumenta-se que isto somente interessa ao capital e por isso há organizações sociais e sindicais, bem como ONGs que defendem o rompimento das nações com a economia global para reassumir a soberania econômica nacional (Brecher, Costello e Smith, 2000).

Da mesma forma há diferenças culturais entre os atores sociais, paradoxos entre a proteção ao meio ambiente e as necessidades humanas e contradições entre os interesses dos movimentos sociais e entidades sindicais do Norte e do Sul. Por exemplo, a posição de dirigentes sindicais americanos é ilustrativa quanto ao último aspecto na crítica que fizeram ao seu governo pelo estabelecimento de "Relações Comerciais Normais e Permanentes" com a China em 2000 e a perspectiva de "um programa de pleno emprego para as pessoas na China em detrimento da perda de um milhão de postos de trabalho nos Estados Unidos" (Jimmy Hoffa Jr. apud Brecher, Costello e Smith, 2000).

Por fim, a identidade dos quatro atores relacionados ao regime trabalhista, além de diferenciada, chega a ser contraditória. No caso das EMNs incluídas neste grupo, não há como ignorar que, antes de tudo, a natureza de uma empresa é buscar a maximização do lucro, o que frequientemente se choca com os direitos trabalhistas e outras questões sociais defendidos pelos demais atores. Quando isso ocorre pode haver conflitos, localizados ou generalizados que às vezes sequer são resolvidos, mas também podem acontecer negociações que levem a acordos, inclusive, em nível internacional.

Todavia, do lado das entidades sindicais, movimento social e ONGs, procura-se atenuar as contradições por meio do diálogo e busca de convergência política uma vez que há, pelo menos, um ponto em comum que é o interesse em transformar a realidade. Freqüentemente, os atores sociais desenvolvem objetivos comuns, mesmo a partir de 
motivações diferentes e até contraditórias. Por exemplo, a oposição ao "Acordo de Livre Comércio das Américas" (Alca) incluiu sindicatos do Norte que temiam o deslocamento de empregos para o Sul, sindicatos do Sul que temiam a perda de empregos devido ao livre trânsito de bens a partir do Norte, pequenos produtores rurais que temiam a concorrência com produtos agrícolas mais baratos de outros países, ONGs ambientalistas que eram contrários aos produtos transgênicos e assim por diante, incluindo os que simplesmente pretendiam defender a soberania nacional.

Esta diversidade de identidades e de conteúdo quanto aos interesses produz formas de ativismo transnacional em níveis diferenciados. Khagram, Riker e Sikkink identificam três formas diferentes de ações coletivas a depender da identidade e dos recursos que os atores sociais dispõem:-

1. Rede transnacional que é o formato mais informal de organização onde os atores trocam informações e discursos através das fronteiras, freqüentemente sem manter contatos face a face e somente utilizando os meios modernos de comunicação;

2. Coalizão transnacional que implica em nível superior de coordenação do que a existente nas redes. Neste caso os atores se conectam internacionalmente e coordenam estratégias comuns e/ou conjuntos de táticas para influenciar transformações sociais publicamente, quase sempre, por meio de campanhas. Estas podem ser "não-institucionais" como os boicotes internacionais ou institucionais utilizando mandatos domésticos ou de OIs. Este formato requer contatos pessoais para definir estratégias, táticas e avaliações.

3. Movimentos sociais transnacionais que são conjuntos de atores com propósitos comuns e identidade mais forte, vinculados internacionalmente e com capacidade de coordenar e sustentar mobilizações sociais em mais de um país para também influenciar transformações sociais publicamente. Diferentemente dos formatos anteriores, os 
movimentos sociais possuem constituintes que eles podem mobilizar para ações coletivas de protesto ou de ruptura da ordem. (2002).

As estratégias e conjuntos de táticas adotadas atualmente pelas entidades sindicais, movimento social e ONGs para tornar o regime trabalhista mais eficaz, particularmente, em benefício dos trabalhadores mais vulneráveis, além das atuações institucionais como na OIT, adotam, principalmente, o segundo e o terceiro formato.

\subsection{O Movimento Social: organizações sociais e não-governamentais}

A partir dos anos 1980 houve um crescimento significativo das organizações sociais e, principalmente, das organizações não-governamentais e não apenas na quantidade como também na sua qualidade.

Há várias explicações para este crescimento. Offe menciona, entre outras razões, a

[...] incapacidade das instituições políticas e econômicas para perceber e atuar com eficácia sobre as privações que afetam os planos fundamentais da vida física, pessoal e social dos indivíduos e que levam à colonização do mundo da vida gerando novas formas de controle social (apud Gohn, 1997).

Dessa forma, "surgem novos movimentos sociais, cujo modo de atuar politicamente aparece como uma resposta racional a um conjunto específico de problemas" (Offe apud Gohn, 1997).

As privações mencionadas eram decorrentes das mudanças do paradigma de acumulação capitalista, bem como das transformações políticas e aberturas democráticas que acompanharam esta mudança em vários continentes. O paradigma do movimento social após o fim da segunda guerra mundial apoiado no crescimento e na seguridade social mudou nos anos 1970 e passou a incluir temas como a ecologia e o meio ambiente, o 
feminismo, a paz, a oposição à energia nuclear, o movimento estudantil, entre outros temas (Offe apud Gohn, 1997).

Johnston, Laraña e Gusfield citados por Maria da Glória Gohn apontam algumas características que oferecem uma base para o chamado "Novo Movimento Social":

[...] sociedade transcendeu a estrutura de classes, a pluralidade de idéias e valores ascendeu, surgiram novas dimensões de identidade, obscureceu-se a relação entre o individual e o coletivo, aspectos pessoais e íntimos da vida humana foram incluídos na agenda, surgiram novas táticas de mobilização de ruptura e resistência como a desobediência civil e a nãoviolência, houve perda de credibilidade dos canais convencionais de participação democrática e os partidos políticos de massa tradicional se centralizaram e burocratizaram (1997).

Em resumo, a classe operária que na visão marxista era a vanguarda das transformações sociais e de fato exerceu um papel preponderante nas conquistas políticas e sociais desde o século XIX até o advento do neoliberalismo, perdeu esta posição para os excluídos que o "novo movimento social" buscou organizar ou representar. Porém, apesar da ascensão deste "movimento novo" e os impactos de várias mobilizações, inclusive com caráter transnacional como a de Seattle em 1999 e outras, ele dificilmente será considerado transformador na acepção marxista como era visto anteriormente o movimento operário. Castells ao analisar o movimento social urbano não o considerava sequer um agente de transformação e sim um ator que contribuía para a democratização da gestão das cidades ao identificar as necessidades coletivas (apud Gohn, 1997).

Offe também chamou a atenção para as dificuldades de continuidade do movimento social devido à fragilidade de suas estruturas organizativas, estratégia de resistência, falta de programa político definido e carência de lideranças marcantes (apud Gohn: 1997). Tarrow afirma que "os movimentos sociais ocorrem quando as oportunidades políticas se 
ampliam, quando há aliados e quando as vulnerabilidades dos oponentes se revelam" (apud Gohn, 1997).

De fato, se olharmos para o histórico recente do movimento social, a sua dinâmica em termos de capacidade de mobilização é cíclica e os temas também variam de um momento a outro. Por exemplo, o banimento do trabalho infantil foi objeto de uma campanha mundial em meados dos anos 1990, envolvendo sindicatos, organizações sociais, ONGs, empresas e governos e obteve resultados positivos na redução do problema. No entanto, apesar disso, dez anos depois, o número de crianças trabalhando ainda é grande, mas já não existe campanha ou outras iniciativas, salvo o trabalho rotineiro das organizações sociais e sindicatos que se dedicam ao tema.

Outro exemplo, é o movimento anti-nuclear que foi muito forte nos anos 1970, principalmente na Europa, em função das preocupações ecológicas e da corrida armamentista da guerra fria, e conseguiu que vários países deixassem de gerar eletricidade por meio de usinas atômicas. No entanto, até hoje o destino do resíduo nuclear continua sem solução e embora a guerra fria tenha terminado, o número de países detentores de armas nucleares aumentou, mas o movimento social não mobiliza mais em torno deste tema, pois, por várias razões, a agenda mudou. Atualmente a prioridade em relação ao tema ambiental é a mudança climática e quanto à paz, a preocupação geral gira em torno de alguns dos muitos conflitos regionais, como Darfur e Palestina.

Embora o movimento social tenha estas características de pluralidade, flexibilidade, pragmatismo e experimentação de diversas ideologias, os seus componentes se constituem de várias maneiras, entre elas as organizações de trabalhadores, estudantes, camponeses, mulheres e outras com membros filiados que pagam quotas e que possuem hierarquia e estrutura, além de outros tipos de associações e as ONGs. 
Estas últimas cresceram numericamente de forma extraordinária durante os anos 1990 e de acordo com Khagram, Riker e Sikkink seriam em torno de 30.000 no final da década que operariam programas internacionais (2002).

Embora algumas ONGs, particularmente, as americanas possuam redes de pessoas associadas que as sustentam financeiramente, normalmente elas não prestam contas politicamente a nenhum grupo social, nem mesmo àqueles aos quais eventualmente prestam serviços de intermediação junto ao Estado, a não ser por intermédio dos resultados de suas ações. É muito diferente nas organizações que possuem hierarquia e dirigentes eleitos pelos membros filiados que para serem reconduzidos à direção necessitam manter uma boa relação com seus constituintes.

O fato de não terem membros filiados não significa que as ONGs não tenham capacidade de mobilização. Por exemplo, a campanha contra a fome e a miséria capitaneada por Betinho, presidente da ONG brasileira IBASE, no início dos anos 1990, seguramente envolveu mais pessoas do que qualquer outra organização social já conseguiu.

As ONGs, portanto, não trazem membros ou "representados" para as mobilizações, mas contribuem com informações, propostas, assessoria, articulações, recursos materiais, entre outros que podem engajar a opinião pública e fortalecer o movimento social.

Muitas organizações sociais e ONGs assumem a defesa de algumas das normas fundamentais de trabalho, em particular as que se relacionam com os interesses e necessidades de setores sociais excluídos ou vulneráveis como crianças, mulheres, trabalhadores precários e informais, minorias étnicas, pessoas em situação de trabalho forçado. Entre as organizações sociais e as não-governamentais que participam regularmente de ações transnacionais em defesa de direitos trabalhistas podemos mencionar:- Anistia Internacional, "Anti-Slavery International”, Juventude Operária 
Católica, "Consumers International", Mórmons Internacional, "Clean Clothes Campaign", "Human Rights Watch", "Labour Net", "Street Net", Coalición por la Justicia para las Maquillas, "Sweatshop Watch", "Bank Watch", "Multinational Monitor", "Global Exchange", SOMO, Instituto Observatório Social, Oxfam, Instituto Max Havelaar, entre muitas outras. Algumas destas serão vistas mais de perto na análise do ativismo social transnacional do próximo capítulo.

As ações coletivas transnacionais dessas organizações acima em relação ao regime trabalhista internacional dizem respeito principalmente à abolição do trabalho forçado e obrigatório, abolição do trabalho infantil, combate à discriminação, proteção às mulheres no trabalho e salário igual para trabalho igual, proteção aos idosos, acesso dos povos indígenas à terra e seus recursos naturais, proteção ao emprego, condições justas de trabalho, condições de trabalho seguras e sãs, remuneração justa, direito à seguridade social, direito de acesso à função pública, proteção aos imigrantes, entre outras.

\subsection{As organizações sindicais}

A primeira atividade transnacional com caráter sindical foi a criação da Associação Internacional dos Trabalhadores (AIT), conhecida como a I Internacional, quando se realizou em 1864 um encontro de ativistas sindicais, anarquistas e socialistas em Londres para debater a difícil situação da classe operária européia diante das péssimas condições de trabalho impostas pela revolução industrial e do desemprego que afetava naquele momento, principalmente os trabalhadores do setor têxtil.

A iniciativa surgiu exatamente a partir da necessidade de uma maior articulação dos trabalhadores deste setor industrial na Europa, pois a indústria têxtil se encontrava em crise devido à guerra civil americana que impedia a importação da principal matéria prima, o algodão. Durante o encontro houve várias discussões sobre as condições de trabalho na 
indústria da época e a necessidade da redução da jornada de trabalho, embora sem adotar qualquer decisão formal, exceto a criação da própria AIT.

Nos dois primeiros congressos da AIT, respectivamente em Genebra e Lausanne na Suiça em 1866 e 1867, o assunto da redução da jornada de trabalho voltou à baila com a proposta de fixação de uma jornada de oito horas diárias como sendo suficiente e a eliminação de todo trabalho noturno, salvo em atividades previstas pela lei.

O terceiro congresso da AIT se realizou em Haia na Holanda em 1872 e decidiu mudar a sede da I Internacional para New York para escapar do ambiente repressivo na Europa daquele momento, o que na prática significou o fim da organização, agravado pela recessão econômica de 1873 que atingiu quase todos os países industrializados e afetou gravemente a organização operária devido ao desemprego. Em 1876, ocorreu o último congresso da AIT já bastante esvaziado.

Foi uma experiência que durou apenas nove anos em termos mais práticos e reunia apenas ativistas dos países industrializados da época. No entanto, deixou um legado importante ao reconhecer a dimensão internacional da exploração dos trabalhadores e a necessidade de articular uma resposta igualmente internacional. A continuidade dos contatos entre os movimentos operários dos diversos países europeus amadureceu a idéia da criação de uma II Associação Internacional de Trabalhadores.

Por ocasião da celebração dos cem anos da Revolução Francesa, em julho de 1889 reuniu-se em Paris um congresso operário socialista com o intuito de criar uma nova organização para substituir a primeira AIT. Eram cerca de quatrocentos delegados de 19 países, quase todos comprometidos com as idéias marxistas e que declararam seu objetivo de emancipar os trabalhadores, abolir o trabalho assalariado, bem como criar uma sociedade onde todos os homens e mulheres, independente de seu sexo e nacionalidade, usufruirão da riqueza produzida pelo esforço de todos os trabalhadores (Sassoon, 1996).

O funcionamento desta Internacional foi especialmente marcado pelas questões das conquistas políticas e econômicas do proletariado na época e de como se posicionar frente ao imperialismo ascendente. No entanto, o posicionamento sobre estas questões nunca foi unânime, pois a expansão da organização operária, mesmo no limite da Europa, não foi homogênea, acontecendo de forma diferente em cada região, dependendo da tradição sindical e partidária de cada país. Por exemplo, na Inglaterra, os sindicatos dos 
trabalhadores na indústria foi o veículo para estabelecer o Partido Trabalhista; na Alemanha, o partido social democrata dirigia as organizações sindicais e na França, socialismo e sindicalismo se desenvolveram paralelamente.

Apesar destas diferenças, na resolução aprovada constaram várias reivindicações e propostas que fizeram história como o apoio à jornada de oito horas, abolição do trabalho infantil e igualdade de oportunidade de trabalho e salário entre homens e mulheres. A Internacional também decidiu adotar o dia primeiro de maio como o "Dia dos Trabalhadores" em homenagem aos mártires da greve pela redução da jornada de trabalho em Chicago em 1886 e posteriormente adotou o dia 8 de março como o "Dia Internacional da Mulher". Por fim, o congresso assinalou que os capitalistas governavam porque possuíam o poder político e diante disto, os trabalhadores deveriam disputá-lo nos países aonde possuíam o direito ao voto apoiando os candidatos dos partidos socialistas e onde não o tivessem, deveriam lutar por todos os meios para obter o sufrágio (Sassoon, 1996).

Alguns ativistas sindicais do setor metalúrgico, madeireiro e têxtil que eram delegados a um congresso da II Internacional em Bruxelas em 1891 aproveitaram a ocasião para se reunir e definir alguns acordos básicos que transcendiam as ações nacionais. Estes foram muito modestos e implicaram basicamente no tratamento igual de seus membros pelos sindicatos de outros países quando eles se empregavam em empresas no estrangeiro, criação de fundos para financiar o intercâmbio internacional de sindicalistas e medidas para evitar que os patrões trouxessem trabalhadores de outros países para "furar as greves". Este foi o embrião dos primeiros secretariados profissionais internacionais (SPIs) que se estruturaram verticalmente filiando sindicatos dos mesmos setores profissionais de vários países, primeiramente europeus e posteriormente de outros continentes (Bendt, 1996).

Em 1914 havia 33 SPIs e hoje eles são apenas dez, a partir da fusão entre várias delas e a tendência é que isto prossiga. Atualmente se denominam Federações Sindicais Internacionais (FSI) e na indústria temos a Federação Internacional de Trabalhadores na Indústria de Metal (FITIM), Federação Internacional de Sindicatos de Trabalhadores da 
Química, Energia, Mineração e Indústrias Diversas (ICEM), Federação Internacional de Trabalhadores de Têxteis, Vestuário e Couro (FTTVC), União Internacional de Trabalhadores da Alimentação, Agricultura, Hotéis, Restaurantes, Tabaco e Afins ${ }^{20}$ (UITA) e a Federação Internacional da Construção e Madeira (FITCM). No setor de serviços públicos e privados há a Internacional de Serviços Públicos (ISP), Internacional da Educação (IE), a "Rede Sindical Internacional"21 (UNI), a Federação Internacional dos Trabalhadores em Transporte (ITF) e a Federação Internacional de Jornalistas (FIJ).

Os objetivos básicos das FSI podem ser resumidos em três aspectos gerais: fomentar a solidariedade internacional, reivindicar e monitorar a vigência de direitos humanos e sindicais e lutar por justiça econômica e social (Bendt, 1996). Embora cada uma delas tenha sua cultura, inclusive derivada dos sindicatos das categorias profissionais que representam, a busca dos objetivos se apóia em medidas de ajuda e proteção aos sindicatos filiados; intercâmbio de experiências, estudos, publicações e produção de informações; representação diante das EMNs do setor em questão; representação diante de organizações e instituições internacionais e desenvolvimento de cooperação internacional (Bendt, 1996).

Em relação aos arranjos do regime trabalhista internacional, citados no segundo capítulo, as FSI atuam principalmente junto a OIT desde sua fundação em 1919 em função do seu caráter tripartite e papel normativo. Particularmente, a Federação Internacional dos Trabalhadores em Transportes teve um papel importante nas discussões sobre as convenções e recomendações dos direitos dos trabalhadores marítimos. Algumas FSI somente começaram a ampliar seu trabalho junto a outras Organizações Internacionais

\footnotetext{
${ }^{20}$ A Federação Internacional de Trabalhadores em Plantações, Agricultura e Similares (FITPAS) se uniu a UITA em 1994.

${ }^{21}$ A UNI engloba os trabalhadores do setor de comunicações, serviços financeiros, entretenimento e técnicos em geral.
} 
como o FMI e Banco Mundial quando estas começaram a promover os ajustes estruturais neoliberais dos anos 1980 ou junto ao GATT quando, na mesma época, os acordos de liberalização comercial se ampliaram e na década de 1990 todas se envolveram na demanda pela "Cláusula Social" na OMC. Nos dias de hoje se preocupam sobremaneira com a aplicação das Diretrizes para EMNs da OCDE e com a negociação dos Acordos Marco Globais. Algumas como a ICEM se dedicam também à verificação da aplicação do "Pacto Global da ONU", pois algumas EMNs de importância no setor químico aderiram a este esquema.

Sobre a organização sindical internacional horizontal temos que voltar ao início do século XX, pois a primeira iniciativa de criar uma "Central Sindical Internacional" partiu de algumas centrais sindicais nacionais de origem européia que em 1902 fundaram um "Escritório Internacional das Centrais Sindicais Nacionais" cuja denominação foi substituída em 1913 por: Federação Sindical Internacional (FSI). No entanto, o incipiente sindicalismo internacional composto basicamente por organizações da Europa e Estados Unidos, entrou em crise com o início da primeira guerra mundial e tanto a II Internacional Socialista quanto a FSI se extinguiram, pois o nacionalismo superou o internacionalismo operário e colocou socialistas e trabalhadores da Tríplice Aliança (Alemanha, ÁustriaHungria e Império Otomano) contra os da Entente (França, Inglaterra e Rússia).

O fim da guerra possibilitou a reativação da FSI sob a denominação Federação Internacional de Sindicatos, que se tornou mais conhecida como a "Internacional de Amsterdam", onde estabeleceu sua sede. Embora a II Internacional Socialista tivesse encerrado suas atividades, a maioria dos dirigentes da nova federação era composta por integrantes de partidos socialistas que haviam participado dela. 
Em contraposição ao sindicalismo influenciado pela social-democracia foram estabelecidas na mesma época duas outras organizações sindicais internacionais: a Confederação Internacional de Sindicatos Cristãos (CISC), formada em 1920 por dirigentes sindicais influenciados pela doutrina social da Igreja Católica a partir da Encíclica Papal "Rerum Novarum" e a "Internacional Vermelha" em 1921 organizada por sindicatos influenciados pelos nascentes partidos comunistas e apoiada pela União Soviética.

Houve nova interrupção das atividades sindicais internacionais durante a segunda guerra mundial, mas as centrais sindicais nacionais social-democratas e as comunistas se uniram ao término da guerra em 1945 na Federação Sindical Mundial (FSM), pois, afinal de contas, seus respectivos países haviam sido aliados durante o conflito. No entanto, se dividiram novamente em 1948 devido ao início da guerra fria e à formação dos dois blocos geopolíticos, o capitalista hegemonizado pelos EUA e o socialista pela URSS, quando as centrais sindicais social-democratas e outras mais conservadoras criaram a Confederação Internacional das Organizações Sindicais Livres (CIOSL) e as centrais sindicais de tendência comunista permaneceram na FSM.

Este quadro sofreu algumas alterações posteriores. A CISC mudou o nome para Confederação Mundial do Trabalho (CMT) em 1968 e em 2006 fundiu-se com a CIOSL estabelecendo a Confederação Sindical Internacional (CSI). A FSM se manteve mesmo após o fim dos regimes do "socialismo real" do Leste Europeu, porém com um número ínfimo de membros, em sua maioria, provenientes de países asiáticos e do Oriente Médio, pois muitas de suas ex-filiadas se reciclaram e se filiaram a CSI.

Ambas, CSI e FSM possuem organizações regionais nos diferentes continentes, além de manterem relações estreitas com as organizações sindicais verticais. As que são ligadas a FSM se chamam "Uniões Sindicais Internacionais" (USI), mas atualmente 
existem poucas em exercício. Em 1951, a CIOSL estabeleceu um acordo com os SPIs para regular o status e os procedimentos da cooperação mútua, uma vez que os secretariados são entes autônomos, mas que estão no mesmo "campo político" da "Confederação", assim como o já mencionado órgão consultivo dos trabalhadores junto a OCDE, a TUAC.

A CSI é de longe a organização hegemônica no cenário sindical internacional. Possui quatro organizações regionais: a Confederação Sindical das Américas (CSA), a CSI - África, a CSI - Ásia e Pacífico e a Confederação Sindical Pan-Européia (PERC). Há ainda três organizações regionais autônomas e que cooperam com a CSI: a Organização para a Unidade Sindical Africana (OUSA) criada em 1973 quando a Organização da Unidade Africana (OUA) decidiu que somente seria admitida a existência de uma central sindical por país e a relação da OUA com elas seria intermediada pela OUSA; a Confederação Internacional de Sindicatos Árabes (CISA) e a Confederação Européia de Sindicatos (CES) também criada em 1973 para, de forma pluralística, lidar com o desenvolvimento da integração européia.

Para lidar com os processos de integração de outros continentes também há redes e coalizões sindicais. São igualmente autônomas, mas compostas majoritariamente por entidades filiadas a CSI, como a Coordenadora de Centrais Sindicais do Cone Sul (CCSCS) que envolve as centrais sindicais da Argentina, Bolívia, Brasil, Chile, Paraguai e Uruguai para atuar junto ao Mercosul, ocorrendo o mesmo na América Andina frente a Comunidade Andina de Nações CAN) ou na região sul da África frente a "South African Development and Economic Cooperation" (SADEC). No caso da "Asian and Pacific Economic Cooperation" (APEC), que envolve vários países do entorno do Oceano Pacífico, incluindo EUA, Canadá, Chile e Peru nas Américas, há uma rede sindical que acompanha e troca informações sobre o tema. 
Portanto, sobrou pouco espaço para a FSM neste conglomerado mundial. A CSI hegemoniza as relações sindicais transnacionais e também as relações com as OIs como a OIT, ONU, OCDE, FMI, Banco Mundial, entre outras. Na escolha dos representantes dos trabalhadores para o Conselho de Administração da OIT que ocorre tri-anualmente, é raro que a CSI não eleja todos os representantes.

Embora haja exemplos de mobilizações e campanhas onde essa super-estrutura sindical tenha cumprido um papel importante, normalmente, sua forma de operar é por intermédio de "lobby" junto às OIs e governos nacionais desde que haja anuência das centrais sindicais filiadas a CSI dos países em questão.

Sua agenda é a defesa da justiça social, defesa dos direitos humanos e sindicais, proteção ao emprego, combate ao trabalho infantil e escravo e combate à discriminação no mercado de trabalho com ênfase na situação da mulher trabalhadora e dos jovens. Ela também apóia as iniciativas das OIs como, por exemplo, a agenda do trabalho decente da OIT, os Objetivos de Desenvolvimento do Milênio da ONU e o combate a AIDS.

A CSI também tem se dedicado a defender a relação entre comércio e direitos, bem como intervir em relação à mudança climática e seu impacto sobre o mundo do trabalho. No entanto, sua estratégia para ações transnacionais sobre estes temas e os anteriores é inteiramente Estado-centrada, apesar de a violação de direitos partir das empresas. Dessa maneira também segue o mesmo sistema de "enforcement" das OIs para o regime trabalhista internacional, de "cima para baixo", pois sua expectativa é que as entidades sindicais nacionais façam a interação com as empresas até porque muitas delas não admitiriam que uma entidade externa viesse interferir em questões nacionais sem que fosse solicitado. 


\subsection{As empresas}

A mensuração do poder econômico e, conseqüentemente, político das empresas, principalmente as multinacionais, não deixa dúvida ${ }^{22}$ quanto a sua influência internacional, além de possuírem alta autonomia para definir suas políticas.

Porém, mesmo assim e mesmo considerando a existência de uma forte identidade de classe e de interesses entre as empresas em geral, também há contradições marcantes. Para começar, há empresas maiores e menores, parte ou não de uma mesma cadeia de valor, onde, normalmente, as empresas menores dependem das maiores. Se um empreendimento maior, por exemplo, decidir mudar sua linha produtiva, isso pode, no limite, levar fornecedores, isto é, empresas menores, à falência. Por isso, muitas vezes pequenas e médias empresas ficam no meio termo em relação a quem deveriam se aliar politicamente no momento de certas decisões, se aos de sua classe ou a outros setores sociais. Embora as empresas envidem grandes esforços em constituir oligopólios, ainda assim, há concorrências entre elas que muitas vezes implicam no desaparecimento de algumas.

Também é comum verificar que empresas com origem no mesmo país e submetidas às mesmas leis, adotam políticas administrativas diferenciadas, muitas vezes determinadas pela sua origem, por exemplo, se é uma empresa de caráter familiar ou se é uma sociedade limitada e da mesma forma existem tradições e teorias diferenciadas de administração, como a americana, a européia, japonesa, entre outras, que implicam em diferentes comportamentos por parte das empresas, principalmente, quanto às relações de trabalho.

Por fim, a relação com o Estado também é ambígua, pois as empresas privadas querem a menor interferência estatal possível no desenvolvimento de seus negócios e ao

\footnotetext{
${ }^{22}$ Ver página 33.
} 
mesmo tempo dependem da regulação favorável do Estado, em nível nacional e internacional, para que possam se estabelecer ou progredir (Estanque, 2005).

Estas observações demonstram que, independentemente do poder econômico que possam dispor as empresas também "jogam" politicamente e além do caráter de ator transnacional das EMNs, há espaços para relações transnacionais de empresas em moldes semelhantes aos que o movimento social e sindical utiliza junto às OIs. Embora elas prefiram a discussão da regulação econômica em OIs como a $\mathrm{OMC}$, normalmente se dispõem também a participar de negociações de (des)regulação social na OIT, OCDE e outras instituições, até para tentar limitar o alcance dos custos das suas resoluções.

O grupo de empresários da OIT é composto por representantes de organizações empresariais nacionais, normalmente as mais representativas e que também são membros da BIAC que acompanha a OCDE, bem como da Câmara Internacional de Comércio e da Organização Internacional de Empregadores (OIE) que acompanham as atividades das OIs em geral.

No caso dos EUA, é freqüente que os empregadores sejam representados por funcionários de grandes empresas como, por exemplo, a Coca Cola; mas não é sempre que as organizações nacionais de empregadores são consideradas representativas pelas grandes empresas multinacionais. Tampouco é incomum encontrar um presidente de uma EMN acompanhando uma Conferência Anual da OIT, pois a maioria dos representantes das associações empresariais é composta por assessores ou diretores profissionalizados.

No caso das atividades da OCDE, é mais freqüente a presença de donos de grandes empresas ou diretores de grandes multinacionais pela temática normalmente envolvida. No caso da União Européia há uma organização empresarial chamada União de Confederações da Indústria e Empresários Europeus (UNICE) que é a representante deste setor nas 
negociações frente a União Européia. Quando as negociações da Alca ainda estavam em andamento, conformou-se uma "Coalizão Empresarial das Américas" (CEAL) que acompanhava as discussões, inclusive, como organismo reconhecido oficialmente pelos governos.

No entanto, a impressão geral é que as OIs e esses espaços transnacionais são mais importantes para o movimento sindical do que para as EMNs. Embora as atividades ensejem encontros entre as partes elas não costumam proporcionar espaços para negociações além daquelas decorrentes das atividades em si.

Ocorrem muitos entendimentos entre o grupo de trabalhadores e de empregadores durante as atividades da OIT sobre temas e procedimentos, como, por exemplo, a definição da lista de países e violações que serão debatidos na reunião anual do Comitê de Aplicação de Normas, o conteúdo das novas convenções, a definição e programação de estudos temáticos e reuniões especiais, etc. Porém, verifica-se que os empregadores têm endurecido suas posições nos últimos anos, principalmente, na tentativa de evitar resoluções sobre certos temas ou novas normatizações. Recentemente, o Conselho de Administração aprovou a discussão sobre a elaboração de uma convenção para regular o trabalho subcontratado, mesmo com a manifestação de muitas reservas de parte do grupo dos empregadores e quando o assunto foi para debate na Conferência, eles se retiraram da reunião que tratava do mesmo para prejudicar o quórum. Há vários anos a Colômbia tem sido objeto de avaliação no Comitê de Aplicação de Normas da OIT pela violação da liberdade sindical prevista na Convenção 87 devido aos constantes assassinatos de dirigentes sindicais. Contudo, em cada reunião adotava-se, por consenso, alguma medida para aumentar a pressão sobre o governo colombiano para garantir o respeito à vida e integridade dos sindicalistas, embora com os limites da OIT, assinalados no segundo 
capítulo da dissertação ${ }^{23}$. No entanto, na Conferência de 2008, o grupo de empregadores, a pedido de seus membros colombianos, se opôs fortemente à aprovação da nomeação de uma comissão especial da organização para verificar a situação in loco no país e esta resolução não passou. Portanto, o espaço de contatos e negociações existe, mas da mesma forma que o regime de trabalho Estado-centrado, a existência deste espaço, por si só, não garante eficácia e também requer iniciativas de "baixo para cima".

\subsection{As interações entre os atores sociais e sindicais}

As atuações conjuntas do movimento social e do movimento sindical são um fenômeno também relativamente novo apesar da longa existência de ambos. Ocorre que o espaço institucional que o movimento sindical conquistou nos países centrais, expressa por meio da influência sobre os partidos políticos aliados que sucessivamente governaram estes países depois da segunda guerra mundial, e de negociações coletivas rotineiras com as empresas gerou uma grande acomodação ou pelo menos a imagem dela. Segundo Avritzer, as associações de natureza conflitiva como os sindicatos e outras, além de se institucionalizarem em torno de objetivos específicos, "se burocratizaram com temas fixos no passado". Ele vai além ao afirmar que "as transformações históricas recentes mostram a indiscutível redução da influência da vida sindical na vida coletiva, bem como o fortalecimento de outros movimentos formadores de opinião, como, por exemplo, o de direitos humanos". (apud, Vieira, 2001). Hobsbawn que já considerava o movimento operário dividido entre revolucionários e reformistas, afirmou que o mesmo entrou em declínio a partir dos anos 1960 (1994).

\footnotetext{
${ }^{23}$ Ver item 2.1 .1 e em especial a página 56.
} 
Porém, o movimento operário não declinou porque surgiu um novo movimento social, mas sim porque o paradigma de acumulação capitalista mudou. Quando isso ocorreu, o movimento sindical não conseguiu responder adequadamente à nova realidade $\mathrm{e}$ tampouco foi visto pela maioria das sociedades como o instrumento para dar as respostas. Segundo Khagram, Riker e Sikkink, a "globalização enfraqueceu os sindicatos domesticamente" (2002: 20). Para Gallin, o declínio da densidade sindical na maioria dos países industrializados nos anos 1980 e 1990 deve-se principalmente à "desconstrução do setor formal e a desregulamentação do mercado de trabalho no 'heartland' do sindicalismo industrial"' (2001: 231).

O "novo movimento social" tem o mérito de tratar de temas que são de fato novos, como as mudanças climáticas, por exemplo, ou antigos, como os direitos humanos, a ecologia, o feminismo, entre outros, que não eram devidamente tratados no passado pelo movimento social e que tampouco faziam parte da agenda sindical. Portanto, este "novo movimento" é posterior ao declínio sindical assinalado e freqüentemente atua em consonância com o movimento sindical. As manifestações de Seattle em 1999, consideradas o grande marco da "resistência à globalização" foi um destes momentos. O movimento social introduziu a agenda de transformação da realidade nas manifestações ao se opor ao "livre comércio" e a OMC, o mote para chamar a atenção da opinião pública, mas a ampla maioria dos manifestantes eram trabalhadores sindicalizados e ativistas sindicais. Muitos denominaram a mobilização em Seattle de aliança "verde-vermelha" ou a aliança entre "tartarugas e caminhoneiros" ("turtles and teamsters") por unir sindicatos e organizações ambientalistas.

As referências à institucionalização, burocratização, enfraquecimento doméstico e declínio têm sua razão de ser, mas é necessário ponderar o alcance real destas afirmações, 
pois o movimento sindical não se estabeleceu mundialmente de forma homogênea e nem sob as mesmas circunstâncias. Por exemplo, Silver e Arrighi mencionam que a expansão das indústrias de produção em massa, particularmente, de automóveis e eletrônicos, para países do Terceiro Mundo como a África do Sul, Brasil e Coréia do Sul engendrou a expansão de uma classe trabalhadora nova, militante e com poder significativo. Estes movimentos trabalhistas no Sul, não apenas conseguiram melhorar salários e condições de trabalho, como também jogaram papéis proeminentes nos movimentos pró-democracia (2005: 277).

O movimento sindical é parte do movimento social mais amplo, mas possui algumas características que o difere de outros parceiros do movimento social e das ONGs, pois a sua relação com o Estado é normalmente mais próxima do que outras organizações sociais e, além disso, os sindicatos possuem constituintes e hierarquia. Isso produz uma dinâmica onde os dirigentes sindicais buscam defender os interesses dos trabalhadores filiados aos seus sindicatos e prestam conta disso para se manterem na posição de dirigentes na hierarquia. Esta defesa de interesses passa pela interação com o Estado e empresas por meio de uma atuação constante, pois sempre há demandas a serem defendidas, além da gestão dos serviços que eventualmente os sindicatos prestam a seus membros.

Atualmente o movimento social incorporou uma série de temas que não faziam parte de sua agenda tradicional de defesa do salário, emprego e direitos sociais como os direitos humanos, as questões ambientais, igualdade de oportunidades entre os gêneros, entre outros. Da mesma forma, uma parte importante do movimento social assumiu o regime trabalhista internacional na sua agenda.

Entretanto, as diferenças existentes entre movimento social e outras organizações sociais e ONGs, estabeleceram viés de preconceitos de todos os lados. O movimento 
sindical via o "novo movimento social" como uma composição de ONGs sem representatividade e o "novo" via o movimento sindical como o "velho movimento social" burocratizado e acomodado, o que gerava muitas tensões (Spooner, 2005: 18 - 20).

Essa dicotomia começou a ser rompida recentemente, pois o aprofundamento do neoliberalismo tornou a conjuntura difícil para todos, "velhos" e "novos". Ao mesmo tempo, alguns processos como, por exemplo, a União Européia, estabeleceram espaços transnacionais compartilhados por sindicatos, empresas, organizações sociais e ONGs por meio do Conselho Econômico e Social. Embora as organizações sindicais internacionais reajam com muita força contra qualquer menção de transformar o tripartismo em quadripartismo cresceu o seu respeito pela atuação, principalmente de ONGs, junto às OIs que lidam com direitos humanos e com o meio ambiente, pois elas em geral possuem grande especialização para tratar destes temas.

O tema que possivelmente mais favoreça a atuação conjunta do "novo movimento social" e o movimento sindical é o relacionado a gênero, pois muitas ativistas sindicais se encontram numa situação única de se envolverem ao mesmo tempo na luta pelos direitos das mulheres no local de trabalho como a não-discriminação por razões de gênero, salário igual para trabalho igual, direito a creches, ampliação da licença maternidade, entre outros e também atuarem no movimento feminista contra a violência doméstica, bem como em defesa de políticas públicas e mudanças culturais. Desta forma se constitui na prática um “feminismo sindical” (Fonow e Franzway, 2007: 165). Há uma série se movimentos sociais recentes que puseram as questões de gênero, inclusive relacionadas às questões sociais e de trabalho, no centro de sua atuação como a Marcha Mundial de Mulheres que atua desde 2000 (Gohn, 2008). 
Por fim, a participação conjunta em algumas campanhas como as de oposição ao Cusfta e Nafta quando se formaram amplas coalizões sociais, primeiramente no Canadá e depois nos EUA, também provocou aproximações. Em vários países da América Latina existe uma tradição de cooperação entre os diferentes movimentos sociais desde a campanha pela redemocratização do país iniciada na segunda metade dos anos 1970. Além disso, as organizações sindicais nacionais e transnacionais participam ativamente do Fórum Social Mundial desde sua segunda edição em 2002 compondo, inclusive, seu comitê organizador internacional. No próximo capítulo veremos como esta aproximação foi importante na luta pela implementação de direitos trabalhistas no plano internacional.

\section{AS INICIATIVAS PARA MUDAR A POLÍTICA TRABALHISTA DAS}

\section{EMPRESAS}

\subsection{Introdução}

Apontados os principais problemas nas relações de trabalho decorrentes do presente paradigma de acumulação capitalista e alguns dos instrumentos existentes no regime trabalhista internacional para lidar com eles, cabe agora avaliar o desempenho dos atores sociais na esfera transnacional.

Contudo, no âmbito dos milhares de EMNs e subsidiárias e seus milhões de fornecedores não existem dados estatísticos que permitam realizar comparações quanto a seus progressos ou regressões no respeito aos regimes internacionais de caráter social como os direitos humanos, trabalhista e ambiental. O único dado concreto é o aumento do número de relatos sobre violações, no entanto, como observa Ruggie, isso só prova que aumentou o número de atores que acompanham este tema, bem como aumentou a transparência das empresas nos dias atuais em comparação com o passado (2006a).

Uma pesquisa conduzida por Ruggie na sua função de "Representante Especial do Secretário Geral da ONU para Direitos Humanos e Empresas Transnacionais e Outros 
Negócios" sobre a política de direitos humanos das 500 maiores empresas no mundo, assim classificadas pela "Forbes Magazine", quanto aos direitos humanos obteve 102 respostas. Estas revelaram que nove entre dez empresas possuem um conjunto explícito de princípios ou normas gerenciais quanto à consideração dos direitos humanos nas suas operações. Todas as empresas que responderam positivamente afirmaram que as políticas de nãodiscriminação, bem como de saúde e segurança no local de trabalho, eram parte deste conjunto de princípios ou normas. Quanto ao referencial em instrumentos internacionais de proteção dos direitos humanos para aplicar suas políticas, 75\% responderam que eram convenções ou declarações da OIT, 62\% mencionaram a "Declaração Universal de Direitos Humanos" da ONU, 50\% o "Global Compact da ONU" e 40\% diziam se referenciar nas "Diretrizes para EMNs" da OCDE. Nove de cada dez empresas que responderam, afirmaram que possuem sistemas internos de acompanhamento de suas políticas de direitos humanos e sete de cada dez relataram que o colocam à disposição pública por meio de publicações ou internet. A maioria destas empresas indicou que atua em conjunto com as partes interessadas identificadas em primeiro lugar como ONGs, seguidas, pela ordem, por associações empresariais, ONU ou outras OIs, sindicatos e, por último, os governos (2006b).

Outra pesquisa realizada pela OCDE em conjunto com o GRI, envolvendo 89 empresas européias e 281 de outras origens detectou que $92 \%$ aplicavam políticas de RSE com base no conteúdo do Pacto Global da ONU, 64\% da Declaração Tripartite da OIT sobre EMNs e Políticas Sociais e 55\% das Diretrizes para EMNs da OCDE (OCDE, 2009).

São todos dados importantes, no mínimo, porque demonstra que um número significativo de empresas multinacionais de grande porte conhece e afirma aplicar os instrumentos de direitos humanos e do regime trabalhista internacional. No entanto, isso não nos dá segurança de que efetivamente cumprem o que afirmam e tampouco significa que as empresas que não responderam às pesquisas não tenham também políticas de responsabilidade social. O quadro fica ainda mais difuso se extrapolarmos esse raciocínio para o conjunto de EMNs, subsidiárias e fornecedores.

Diante disso, a avaliação que consta neste quarto capítulo da dissertação está baseada em alguns exemplos qualitativos de iniciativas em prol do efetivo cumprimento do regime 
trabalhista internacional, tanto das tentativas de utilização dos arranjos "Estado-centrados" contra as violações de direitos, quanto da utilização dos arranjos com caráter mais privado.

\subsection{Os limites da coerção estatal}

A OIT por mais de sessenta anos foi o único fórum a administrar a aplicação do regime trabalhista internacional do modo descrito no segundo capítulo da dissertação. Atualmente, de certa maneira, compartilha esta tarefa com várias outras organizações internacionais - OCDE e ONU - bem como, com instituições regionais - UE, Nafta, Mercosul e outras.

Esta ampliação dos fóruns internacionais que lidam com o regime trabalhista, contribuiu para ampliar a percepção da sociedade sobre estes direitos e assim fortaleceu a vontade política para que sejam devidamente respeitados, mas não criou mecanismos de coerção para que isto ocorresse de maneira mais eficiente e dificilmente criará. A tentativa mencionada no Capítulo 2 de introduzir uma "Cláusula Social" na OMC para utilizar seu poder coercitivo por meio das sanções comerciais foi amplamente rechaçada e a tentativa de dispor o Conselho de Direitos Humanos da ONU de um instrumento com capacidade de punir empresas que violarem suas 23 normas relacionadas a direitos humanos, trabalho e meio ambiente, por meio de indenizações financeiras aos prejudicados, tampouco arregimentou grandes apoios e também repousa em "berço esplêndido". Segundo Ruggie, "se as normas internacionais simplesmente reproduzem princípios jurídicos internacionalmente estabelecidos, não podem então obrigar diretamente as empresas a cumpri-las, com raras exceções". Para ele, a única instituição internacional que lida com a violação de direitos humanos e que possui "Hard Law" é o "Tribunal Penal Internacional”, que possui o poder de punir cidadãos com penas de prisão nos casos de participação em 
genocídios e determinados crimes de guerra. Ele, no entanto, considera positivos os atuais mecanismos internacionais para lidar com os direitos humanos e trabalhistas, mesmo com base na "Soft Law",24, pois considera que "as iniciativas voluntárias no presente poderão se transformar em regras vinculantes no futuro" (2006a). Esta posição foi criticada por muitas organizações sociais e ONGs, bem como por outros estudiosos do tema por negar a responsabilidade penal de pessoas jurídicas no caso de qualquer violação de direitos humanos ou do regime trabalhista (Teitelbaum, 2006).

De fato, a expectativa geral da sociedade e dos movimentos sociais é que o Estado cumpra sua obrigação de proteger os cidadãos, inclusive em nível internacional. Por isso, no que tange o regime trabalhista internacional, aumentaram as reivindicações por maior "enforcement". Porém, o esforço empreendido pelo movimento sindical e social ao longo dos anos 1990 para obtê-lo por intermédio de tratados vinculantes, conforme já mencionado, somente resultou em maior cobertura das OIs quanto às Normas Fundamentais de Trabalho e sempre com caráter voluntário.

Do ponto de vista preventivo e de conscientização sobre a existência de direitos trabalhistas fundamentais isso foi importante, mas do ponto de vista do remédio jurídico diante de danos ocorridos o efeito foi limitado, não apenas pela ausência de poder coercitivo das OIs, mas também porque os procedimentos que elas normalmente exigem para apresentar queixas e dar atendimento a elas são burocráticos e lentos. Por exemplo, qualquer sindicato, organização social ou ONG pode encaminhar uma queixa a OIT sobre violação da liberdade sindical com base nas Convenções 87 ou 98 ou, ainda, da "Declaração de Princípios e Normas Fundamentais" por uma determinada empresa. A reação da OIT será, em primeiro lugar, solicitar esclarecimentos do governo do país em questão e após o posicionamento deste, analisará o caso à luz das alegações apresentadas na queixa e na resposta governamental. Isso levará, na melhor das hipóteses, quatro meses que é o intervalo entre uma reunião e outra do seu Comitê de Liberdade Sindical e o parecer deste, por mais que seja favorável ao queixoso, pode ser no máximo uma orientação ou

\footnotetext{
${ }^{24}$ O termo "Soft Law" é comum no direito internacional e são leis com ausência de responsabilização e de mecanismos de coerção (Nasser, 2002: 10). É o oposto de "Hard Law".
} 
recomendação para o governo do Estado-Nacional adotar determinadas providências de ordem legal para evitar que problemas semelhantes se repitam e para que a empresa em questão corrija seu comportamento. A OIT não se dirigirá à empresa em nenhum momento.

Este procedimento diplomático e cuidadoso se aplica até mesmo em situações extremamente graves como no caso do governo militar de Myanmar que costuma recrutar a população local para trabalhar compulsoriamente em obras de infra-estrutura básica, como abrir estradas e aplainar terrenos, para facilitar a instalação de indústrias multinacionais e assim atrair investimentos diretos externos. Após mais de dez anos de discussões e reprimendas sobre esta prática que caracteriza trabalho escravo, o Comitê de Aplicação de Normas da OIT suspendeu o direito a voto deste país na OIT. Estas condenações por si mesmas não levaram a mudanças de atitudes, mas forneceram uma base moral e política para a campanha internacional lançada para convencer uma série de EMNs a não investirem em Myanmar ou retirarem seus investimentos como forma de pressão sobre a Junta Militar que governa o país para restabelecer a democracia e cessar com a violação dos direitos humanos e sindicais. A divulgação em nível mundial de uma "lista suja" de empresas que faziam negócios em Myanmar e o lobby realizado por organizações sindicais, ONGs e um Fundo de Investimento Ético dos EUA (Franklin Research and Development Corporation) convenceu várias delas como as cervejarias Carlsberg e Heineken, a indústria de vestuário Levis Strauss, as cadeias de comércio Liz Claiborne e Macy’s, entre outras, a cancelá-los. (Burma Campaign, 2009).

Em algumas ocasiões na década de 1990, o governo brasileiro foi também chamado a prestar contas de suas iniciativas de promoção da igualdade racial no mercado de trabalho, no mesmo Comitê de Aplicação de Normas em função de uma denúncia apresentada pela Confederação Latino Americana de Trabalhadores (CLAT) com base na Convenção 111 que pró́be qualquer tipo de discriminação no local de trabalho. A base desta denúncia eram os dados de renda levantados pelo IBGE e que demonstravam que um trabalhador branco no Brasil tinha um salário médio duas vezes superior ao de uma trabalhadora branca, três vezes ao de um trabalhador negro e quatro vezes ao de uma trabalhadora negra, bem como a existência de uma série de ações judiciais pedindo a reintegração ao emprego de trabalhadores que alegavam demissões por discriminação racial. $\mathrm{O}$ debate gerado 
anualmente nas Conferências em torno do tema e que inicialmente não foi provocado por nenhuma organização sindical brasileira levou a dois resultados interessantes:

- ampliou a ação do Estado sobre o tema, levando à criação de critérios mais precisos do Ministério do Trabalho e Emprego para monitorar a discriminação e culminando na aprovação de uma lei específica de repressão á discriminação racial no local de trabalho de autoria da Senadora Benedita da Silva;

- ampliou o engajamento da base sindical brasileira em torno do assunto e as três centrais sindicais brasileiras na época tomaram a iniciativa em 1995 de criar uma ONG para lidar com a promoção da igualdade racial no mercado de trabalho com a participação da Organização Interamericana de Trabalhadores (ORIT) (precursora da CSA) e uma entidade americana chamada "Coalition of Black Trade Unionists" (CBTU), por sua vez apoiada pela central sindical dos EUA, a AFL-CIO. Esta ONG possui uma dimensão internacional, embora atue basicamente no Brasil. Chama-se "Instituto Sindical Interamericano pela Igualdade Racial” (INSPIR) e em 1999 causou uma grande repercussão ao publicar um estudo sobre o desemprego no Brasil que demonstrou seu viés racial por afetar mais os trabalhadores negros do que os não-negros, mesmo na região metropolitana de Salvador onde $80 \%$ da população são afro-descendentes.

A OIT afirma ainda que seus procedimentos geram impactos positivos como, por exemplo, as atividades do Comitê de Liberdade Sindical:

Durante um período de 25 anos, mais de 60 países de cinco continentes, num momento ou outro, adotaram medidas recomendadas pelo Comitê de Liberdade Sindical ou prestaram informações sobre mudanças positivas em relação à liberdade sindical concernentes a queixas examinadas pelo Comitê (Gravel, Duplessis e Gernignon, 2001: 23).

Como este exemplo, há outros, mas que somente reforçam a avaliação geral de que os resultados da atuação da OIT são de lenta maturação e que o organismo não é eficaz diante de demandas trabalhistas imediatas. Por exemplo, um dirigente sindical que tenha seu contrato de trabalho suspenso arbitrariamente por uma empresa não pode aguardar meses por um parecer da OIT que lhe favoreça, ainda mais porque o parecer por si só não resolve o problema, já que ela não tem poder para obrigar a empresa a reverter sua atitude.

No entanto, há pelo menos um exemplo interessante da utilização de um regime internacional para favorecer o resultado imediato de uma ação sindical. Foi em 1997, 
quando o governo sul-coreano promoveu uma reforma na legislação trabalhista limitando sobremaneira a liberdade de organização sindical e a negociação coletiva, além de extinguir uma série de outros direitos dos trabalhadores. Em reação, as duas centrais sindicais da Coréia do Sul convocaram uma greve geral que obteve grande adesão nacional, além de forte solidariedade internacional expressa através da presença de delegações sindicais estrangeiras para acompanhar a greve desde seu início. Neste momento, a Coréia do Sul estava prestes a se tornar membro da OCDE. Porém, é de praxe que os membros desta organização sejam países governados democraticamente e que respeitem a Declaração Universal de Direitos Humanos da ONU e as Normas Fundamentais de Trabalho da OIT. Como a reforma trabalhista promovida pelo governo coreano violava flagrantemente as Convenções 87 e 98 da OIT, foi possível aos dirigentes da TUAC e CIOSL convencer as altas autoridades da OCDE a recusar o ingresso da Coréia do Sul naquelas condições e o governo deste país acabou recuando quanto à reforma pretendida.

Nos casos mencionados de Myanmar e Coréia do Sul a velocidade e a eficiência da reação contra a violação de normas fundamentais da OIT, dependeram em grande medida dos atores sociais ou até da ação de outras OIs. Além disso, a interação entre movimentos sociais, sindicais e a OIT pode assumir formatos diversos, como na iniciativa proveniente do movimento social e sindical que não tinha a intenção de fazer respeitar determinada norma fundamental da OIT, mas sim de provocar a criação de uma delas que foi a Convenção 182 que visa a "Abolição das Piores Formas de Trabalho Infantil”.

O tema trabalho infantil começou a sensibilizar a opinião pública, principalmente a partir dos anos 1980, quando os consumidores europeus tomaram conhecimento da participação de crianças na fabricação de tapetes, roupas e outros produtos importados da Ásia, produtos estes que viam seu consumo crescer nos países desenvolvidos devido à liberalização comercial. Tornou-se público que o trabalho infantil estava presente também em atividades desgastantes até para adultos, como a mineração, produção de fogos de artifício, entre outras, sem mencionar atividades intoleráveis como tráfico de drogas, prostituição, atividades paramilitares, etc.

Surgiram então, algumas das primeiras denúncias e também as primeiras campanhas para promover um "consumo consciente" de produtos socialmente corretos, que, no entanto, não afetavam as atividades que agravavam a violação dos direitos humanos 
infantis. O governo holandês, em cooperação com a OIT, organizou uma conferência em 1997 sobre as formas mais intoleráveis de trabalho infantil e neste mesmo ano iniciou-se a "Marcha Mundial Contra o Trabalho Infantil", organizada por uma série de ONGs e organizações sindicais que reuniu participantes em todos os continentes que se deslocavam - "marchavam" - de um país a outro, organizando eventos para chamar a atenção da opinião pública sobre o tema e que culminou com a sua chegada em Genebra durante a conferência anual da OIT em 1998, quando foi iniciada a discussão sobre uma nova convenção para abolir as piores formas de trabalho infantil e que foi aprovada por unanimidade no ano seguinte sob o número 182. Ela entrou em vigor em 2000 e rapidamente ultrapassou uma centena de ratificações nacionais. Apesar de a medida ter sido avaliada na época como uma articulação bem sucedida entre o movimento social, empresários - pois o grupo de empregadores da OIT foi favorável à Convenção - e instituições governamentais, surgiu uma preocupação de que muitos países poderiam adotar a Convenção 182 e relegar a Convenção 138, que define a idade mínima para o trabalho, a um segundo plano. Isso seria muito contraproducente, pois apesar da gravidade das situações intoleráveis, ainda assim havia milhões de crianças entre cinco e 14 anos trabalhando no mundo, principalmente nos países em desenvolvimento e sob más condições de trabalho danificando sua saúde e sem oferecer outra perspectiva, a não ser, reproduzir sua própria pobreza e trabalho. No entanto, a preocupação não se justificou e a coalizão social que organizou a "Marcha Mundial contra o Trabalho Infantil" manteve esta denominação e transformou-se numa rede permanente de organizações sociais, sindicais e ONGs. Hoje ela investiga e denuncia a ocorrência das piores formas de trabalho infantil, inclusive as situações combinadas de trabalho infantil com escravidão que ocorrem em certos países do sudeste asiático. Os membros da rede chegam até a libertar crianças que se encontram nesta situação, pois mesmo com todo o consenso gerado em torno da aprovação da Convenção 182, ela padece dos mesmos problemas de eficácia das demais.

\subsection{Os limites das iniciativas privadas unilaterais}

Ironicamente, enquanto os diplomatas norte-americanos discursavam em Marrakesh na Conferência de Encerramento da Rodada Uruguai em 1994, a favor de uma "Cláusula Social" na OMC para impedir a competição comercial desleal de manufaturados baratos 
devido à violação de direitos trabalhistas, em particular, das Normas Fundamentais da OIT, executivos de empresas multinacionais dos EUA continuavam instalando fábricas em países onde pudessem exatamente minimizar seus custos trabalhistas devido à legislação trabalhista frouxa ou inexistente ou ainda se empenhavam em subcontratar empresas locais que pudessem supri-los da forma mais barata possível mesmo que isso implicasse na violação de direitos. Esta constatação é somente para registrar que a mudança do comportamento das empresas é talvez a chave principal para solucionar o problema do descumprimento do regime trabalhista internacional, pois, afinal de contas, é no local de trabalho que as violações dos direitos acontecem. O regime trabalhista internacional, como já vimos, tem a capacidade limitada para exigir que os Estados se comprometam a assegurar essa mudança de comportamento por parte das empresas. No entanto, cabe ainda discutir o alcance de eventuais iniciativas unilaterais das próprias empresas, bem como a influência do movimento social e sindical sobre elas para impulsionar o funcionamento do regime trabalhista internacional, enquanto um "bem comum",

Para a teoria econômica marxista sempre haverá a exploração dos trabalhadores pelos empresários, mesmo que esta eventualmente não implique na violação dos direitos trabalhistas fundamentais, pois eles dependem da extração da mais-valia dos operários para acumular capital e a única forma de os trabalhadores defenderem seus interesses e direitos é por meio da luta de classes (Marx, 2008). Cox reforça esta opinião ao afirmar que Karl Marx era cético sobre a "emersão do bem comum a partir da perseguição de interesses individuais" (2005: 105).

Alguns socialistas utópicos que antecederam Marx como Charles Fourier e Robert Owen eram críticos como ele ao industrialismo que se desenvolvia no início do século XIX. Owen, que inclusive era um empresário inglês afirmou:

[...] por pior e mais insensata que seja a escravidão existente na América, a escravidão branca das fábricas inglesas era, nesse período em que tudo era permitido, coisa muito pior que os escravos domésticos que posteriormente vi nas Índias ocidentais e nos Estados Unidos, e sob muitos aspectos, tais como saúde, alimentação e vestuário, os escravos viviam em melhor situação do que as crianças e os trabalhadores oprimidos e degradados das fábricas da Grã Bretanha (Wilson, 2006: 110).

\footnotetext{
${ }^{25}$ Este é um conceito oriundo do pensamento católico e que atribui aos indivíduos buscar solidariamente os fins comuns. Tem sido utilizado mais recentemente na análise econômica dos bens coletivos ou públicos e na concepção neocontratualista (Bobbio, Matteucci e Pasquino, 2004: 106).
} 
Porém, eles acreditavam que a produção industrial poderia funcionar de outra maneira e o mesmo Owen introduziu uma série de mecanismos de gestão na sua indústria têxtil que implicavam em melhores condições de trabalho e o pagamento de salários mais altos para os seus operários por meio de sociedades limitadas e independentes, uma espécie de gestão comunitária de suas fábricas, no interior da sociedade maior (Wilson, 2006).

$\mathrm{Na}$ atualidade, além das visões éticas que derivaram do socialismo utópico de Owen e outros, do socialismo científico de Marx e Engels ou da doutrina cristã, existem também concepções de economia de mercado que justificam a importância do cumprimento do regime trabalhista internacional como os argumentos neo-institucionalistas e até os neoclássicos. Para os neo-institucionalistas que defendem uma perspectiva de crescimento econômico orientado pela demanda do mercado, a alta concentração de renda nas mãos de poucos gera três problemas:- impede a criação de um mercado de consumo massivo; provoca um alto nível de poupança que impede os investimentos necessários ao crescimento econômico e a utilização de mão de obra extensiva, exatamente por ser barata, não amplia a produtividade. Portanto, a promoção dos direitos trabalhistas é fundamental para aumentar salários e distribuir a renda, alavancar investimentos produtivos e provocar o uso de mão de obra mais intensiva e qualificada para gerar maior produtividade. Para promover os direitos, se faz necessária a aplicação de regulações internacionais e domésticas (Scherrer e Greven, 2001).

$\mathrm{Na}$ teoria neoclássica, a eficiência econômica depende da menor interferência possível de fatores estranhos ao mercado, mas o respeito pelas Normas Fundamentais de Trabalho pode ser justificado como uma forma de corrigir suas eventuais falhas. Por exemplo, a liberdade sindical é um meio para os trabalhadores se contraporem ao poder dos empregadores no mercado, pois o poder de negociação de um trabalhador individualmente é muito limitado diante de uma corporação empresarial. O mercado é definido como a troca de bens entre pessoas livres e assim se justifica a proibição do trabalho escravo e infantil. A eventual discriminação no local de trabalho por razões de gênero, etnia, religião ou outras implicará em que as oportunidades de emprego e renda não serão relacionadas ao bom desempenho dos trabalhadores e trabalhadoras. Portanto, o respeito às Normas 
Fundamentais de Trabalho, grosso modo, pode promover a eficiência do mercado (Scherrer e Greven, 2001).

No entanto, quanto a promoção do regime trabalhista internacional como um "bem comum", a teoria econômica neoclássica afirma que há uma tendência de nem todos arcarem com os custos do "bem" e alguns assumirem o papel de "carona", pois uma empresa voltada para exportações, por exemplo, estará pouco preocupada com a eficiência do mercado nacional. Isto poderia ser resolvido por meio do poder coercitivo do Estado, mas de acordo com a análise, também neoclássica, de Samuelson, um bem comum é nãorival quando o consumo de um não depende dos benefícios derivados de outros e, portanto, o "carona" pode ser induzido a cooperar, tanto por intermédio do Estado, quanto por meio da ação privada coletiva. Entretanto, Olson, autor da mesma escola, argumenta que a ação coletiva tende a fracassar quando o interesse particular se sobrepõe, embora admita que alguns grupos possam ter sucesso, principalmente se forem pequenos. Esta dimensão não significa necessariamente que o número de membros do grupo tenha que ser pequeno, mas requer que a dimensão do benefício que cada membro individual venha a receber do "bem comum" seja maior do que o investimento realizado. A indução para participar da ação coletiva pode ser feita por meio de incentivos seletivos, que induzirão outros a cooperar e os grupos organizados podem também ser estimulados a cooperar coletivamente como um produto colateral (Drazen, 2000: 373 - 391). Por fim, para medir o sucesso do empreendimento e detectar "caronas" é necessário dispor de algum tipo de monitoramento ou acompanhamento, aceito pelos membros do grupo.

Estes princípios neoclássicos têm sido aplicados de alguma forma em certos tratados ambientais internacionais. Por exemplo, a Convenção Internacional de Prevenção de 
Poluição de $\operatorname{Navios}^{26}$ que, entre outros objetivos, visa impedir que os navios petroleiros derramem excesso de óleo no mar quando limpam seus compartimentos de carga, é uma convenção que tem sido razoavelmente respeitada pelo setor privado, particularmente, porque as empresas marítimas sentem, em primeiro lugar, que não há desvantagem competitiva em cumpri-la. Ela funciona por meio de uma combinação de estímulo através da introdução de uma nova tecnologia que tornou a limpeza mais eficaz e barata com a sanção indireta de negação da emissão de certificados de não-poluidores e de seguros para os que não respeitarem a convenção, o que impede as embarcações de participar do comércio mundial. Isso substituiu as tradicionais multas e tornou a convenção mais eficaz e para garantir a transparência foi criado um sistema de monitoramento com o qual as empresas cooperam (Mitchell, 1994: 143 e 153).

Por analogia, as empresas que respeitam as normas fundamentais de trabalho e utilizam isto para aprimorar sua imagem diante do consumidor poderiam ser um fator de indução para outras empresas fazerem o mesmo e realmente existem algumas iniciativas neste sentido. Uma das mais conhecidas é a utilização dos "selos de qualidade" ou "Labeling" por empresas que assumiram determinado compromisso ético como, por exemplo, não produzir ou vender tapetes que tenham sido fabricados com mão de obra infantil. Neste caso, o selo tornou-se conhecido como "Rugmark" e passou a ser utilizado intensamente na Europa a partir dos anos 1980 como resultado de uma campanha do movimento social e sindical contra o comércio de tapetes provenientes da Ásia onde eram produzidos com intensa participação de trabalho infantil. Esta campanha gerou vários desdobramentos positivos como a criação da "Rugmark Foundation" que certifica os produtores asiáticos de tapetes e monitora se de fato respeitam o compromisso de não

\footnotetext{
${ }^{26}$ Sua sigla em inglês é MARPOL e entrou em vigor em 1983.
} 
empregarem crianças. A campanha contribuiu, por exemplo, para que a rede sueca de comércio de mobiliário IKEA se tornasse mais cuidadosa com a origem dos produtos que vende. A IKEA e a FITCM assinaram um Acordo Marco Global em 1998 onde esta se comprometeu a garantir o respeito pelas Normas Fundamentais de Trabalho em toda sua cadeia internacional de valor, o que beneficiaria em torno de um milhão de trabalhadores (Scherrer e Greven, 2001). A Fundação ABRINQ no Brasil, uma associação de origem empresarial, também adotou a estratégia de distribuir o selo "Empresa Amiga da Criança" para apoiar a campanha nacional contra o trabalho infantil que foi forte na segunda metade da década de 1990, embora as empresas que utilizam o selo não sejam monitoradas e o seu compromisso na verdade ser com a realização de qualquer medida de RSE em favor das crianças, pois muitas delas nem teriam como empregá-las pela natureza de sua atividade econômica.

Há muitas iniciativas internacionais de "Labeling" como a da ONG holandesa "Instituto Max Havelaar" que vende pó de café e de chocolate na Europa por um preço ligeiramente superior à média de mercado e utiliza esta diferença para custear a orientação e o monitoramento dos produtores de café e cacau em países da América Central e África para garantir que eles adotem padrões ambientais e trabalhistas adequados. Ou ainda o selo "Forest Stewardship Council", de uma entidade internacional que surgiu no bojo da Conferência de Meio Ambiente da ONU em 1992 e que certifica o manejo ético e ambiental da exploração de florestas e plantações para produção de madeira.

O relatório de John Ruggie mencionado anteriormente aponta, a partir de um recorte de 65 denúncias de violações de direitos humanos apresentadas recentemente por ONGs contra EMNs, que a maior parte delas se referia a atividades no setor de mineração e extração de petróleo, seguido de longe pelo setor de agricultura e alimentação e em terceiro 
lugar pelo setor de vestuário e calçados. Várias empresas de mineração têm aderido a iniciativas voluntárias criadas pelo setor para combater a corrupção ou o comércio de diamantes oriundos de zonas de conflito, bem como para garantir o respeito pelos direitos humanos das comunidades locais confrontadas pela segurança empresarial das minas (2006a).

$\mathrm{Na}$ agricultura, pecuária e processamento de alimentos também há várias iniciativas para gerar certificações de boa origem de grãos, algodão, carne e outros produzidos sem danificar o meio ambiente e utilizando boas práticas no campo trabalhista. Há inclusive uma iniciativa de "Labeling" para a produção de flores em alguns países da América Latina e África que são comercializadas na Europa. Uma comissão de sindicalistas, ONGs e empresários se reúnem anualmente e definem quais são as empresas produtoras a receber a certificação a partir de indicadores sobre o respeito à liberdade sindical, negociação coletiva e salário mínimo (Scherrer e Greven, 2001).

No setor de calçados destaca-se a "Fair Labor Association" que apesar de lançada pelo governo dos EUA em 1996 é administrada por 18 empresas, um grupo de ONGs e cerca de 200 lojas de calçados situadas em universidades americanas. A associação criou um programa de padrões trabalhistas, com conteúdo mais amplo do que as normas fundamentais da OIT, que pretende implementar em aproximadamente 4.000 plantas produtivas, dentro e fora dos EUA, através da adesão delas ao programa e colaboração com seu monitoramento.

A maioria das grandes empresas de vestuário atualmente terceirizou a produção das roupas com suas marcas e somente administra a sua qualidade. A americana Levis Strauss é uma delas e que adotou um código de conduta para a operação de suas empresas subcontratadas em 1991 com aspectos ambientais e, principalmente, trabalhistas. A C\&A é 
uma empresa holandesa do setor de varejo, mas que vende roupas com sua marca também produzidas por intermédio de empresas terceirizadas que são constantemente denunciadas por violarem as normas fundamentais de trabalho, inclusive no Brasil pela exploração de imigrantes em situação irregular. Ela evita ao máximo se relacionar com os sindicatos e criou sua própria empresa de auditoria social para monitorar seus fornecedores. $\mathrm{Na}$ Índia onde não possui lojas, mas produz grande parte de suas peças de vestuário, ela implantou alguns programas assistencialistas para melhorar sua imagem.

Atualmente cresce o número de empresas que utilizam instrumentos de mercado como estratégias de responsabilidade social empresarial e surgiram inclusive várias empresas de consultoria especializadas em RSE a partir destas abordagens. A base desta estratégia é "Accountability", termo que não tem equivalente em português, mas que está relacionado a "assumir responsabilidade" e "prestar contas". Uma vez que uma empresa se engaja e adota uma estratégia de RSE, ela deve saber como preparar o relatório sobre o desempenho de sua estratégia cujo processo é chamado de "Assurance" (segurança) e que possui inclusive um padrão internacional conhecido como AA1000AS. De acordo com uma destas empresas de consultoria, "CsrNetwork", atualmente há cerca de 2.800 empresas, a maioria EMNs, que produzem relatórios anuais sobre suas políticas de RSE (Csrnetwork, 2009). De posse deste instrumento a empresa pode fazer "Benchmarking" com seu desempenho de RSE que é uma técnica de administração onde se compara produtos, serviços e práticas empresariais entre empresas líderes ou entre os concorrentes mais fortes de determinado setor, cujo resultado, uma vez favorável, se torna peça de marketing. O mesmo pode gerar "Accountability Rankings" - classificações da qualidade das prestações de contas - de RSE de empresas ou do seu desempenho na área ambiental, social e trabalhista para fins de marketing. Algumas instituições financeiras utilizam o "Ranking" 
como critério para concessão de créditos bancários ou para realizar "Investimentos Éticos". Alguns Fundos de Investimentos criados a partir dos anos 1970 somente adquirem ações de empresas com bom "Ranking" social e ambiental cujos critérios, no entanto, são definidos pelos próprios fundos. Somente nos EUA há 144 deles que administram uma carteira de aproximadamente US\$2,3 trilhões. Há bancos que atuam internacionalmente como o holandês ABN-AMRO que agora pertence ao Banco Santander, espanhol, que também possui um fundo de "investimentos éticos" e faz alguns anos a CIOSL (atual CSI) criou uma comissão para tentar orientar as centrais sindicais dos países desenvolvidos a aplicarem o "capital dos trabalhadores", isto é, seus recursos e os dos Fundos de Pensão que controlam em empresas que respeitam o regime trabalhista internacional.

Portanto, há inúmeros exemplos de engajamento empresarial na promoção de condutas que adotem o regime trabalhista internacional integralmente ou parcialmente, mas cujas motivações são diferenciadas e que variam desde convicções éticas até razões pragmáticas. Há casos de engajamento real a partir da convicção de que respeitar direitos humanos e trabalhistas, bem como o meio ambiente é a melhor maneira de dirigir um negócio e há as empresas que se engajam como estratégia para enfrentar concorrentes e conquistar mercados. Nesta segunda situação, o respeito pelas normas internacionais de direitos humanos, trabalho e meio ambiente pode se transformar numa vantagem comparativa, principalmente, quando se trata de produtos sensíveis para os consumidores como, por exemplo, a relação da fabricação de brinquedos e material escolar com a coibição de trabalho infantil ou a relação da fabricação e venda de perfumes com a preservação do meio ambiente. Podemos mencionar ainda, as empresas que apenas declaram boas intenções, mas que na prática nada fazem e aquelas que são "convencidas" a mudar de atitude em função de pressões e campanhas organizadas pelo movimento social. 
Entretanto, também não faltam os empresários que simplesmente remetem o regime trabalhista internacional ao segundo plano afirmando que as interferências para "artificialmente" mudar as vantagens comparativas dos países em desenvolvimento do Sul, embasadas nos baixos custos de mão de obra, na verdade prejudicarão a participação destes países no comércio mundial e afirmam ainda que a promoção das normas fundamentais de trabalho depende do crescimento e do desenvolvimento econômico somente assegurado por maior crescimento do comércio que, todavia, depende de maior liberalização comercial. Esta visão que parte principalmente de empresas que produzem para a exportação ou que comercializam internacionalmente a produção de terceiros, dificulta a discussão sobre a adoção de padrões trabalhistas mínimos em nível internacional, pois na verdade este tipo de empresas se beneficia da ausência delas, principalmente, ao sub-contratarem sua produção e vendas.

A possibilidade da adoção de padrões trabalhistas em acordos comerciais ou OIs como a OMC com caráter mandatório é rejeitada internacionalmente pelos empregadores por quase unanimidade, enquanto os arranjos voluntários têm maior aceitação. Porém, eles se dividem até mesmo com relação a esta possibilidade. Enquanto alguns empresários aceitam a promoção de arranjos voluntários, como o "Labeling" talvez como forma de evitar outras regras mais vinculantes, outros os rejeitam, pois temem que se transformem em avaliações negativas de outros produtos e produtores, como afirmou um empresário do setor têxtil: "um tapete com selo de qualidade coloca em descrédito todos os outros que não o tiverem" (Scherrer e Greven, 2001).

De qualquer maneira, além da rejeição às normas fundamentais de trabalho que necessita ser enfrentada, há muitas alegações empresariais de respeito a elas por meio da adoção de medidas unilaterais onde não se tem qualquer segurança para reconhecer sua 
validade, o que também demanda acompanhamento social, até para assegurar às empresas de boa fé que suas iniciativas geram efeitos ou ainda para convencê-las que o envolvimento das partes interessadas pode melhorar seus resultados.

\subsection{As ações do movimento social em defesa do regime trabalhista}

\section{internacional}

Antes da mudança do paradigma de acumulação capitalista não se conhecia outros mecanismos de incidência do movimento social sobre os comportamentos empresariais, salvo a tradicional interação dos sindicatos com as empresas em níveis nacionais para negociar contratos de trabalho em nome de seus representados ou de sua participação na OIT. Como exposto no terceiro capítulo, o envolvimento dos atores sociais nas relações transnacionais para transformar realidades tinha como alvos principais os Estados Nacionais e as OIs. Aqui também serão explorados alguns exemplos de incidência do movimento social - entendido como organizações sindicais, sociais e não-governamentais atuando em separado ou em conjunto diretamente sobre o setor privado em nível internacional, o que representa um salto de qualidade no campo das lutas sociais em função dos limites do Estado já mencionados anteriormente na dissertação. Trata-se, no entanto, de um recorte, pois como afirma Amoore "os entendimentos dos sentidos da resistência global junto com a percepção do foco e das possibilidades de resistências concretas são moldados por visões de mundo competitivas" (2005: 2).

A origem das iniciativas exemplificadas neste capítulo serão os três níveis de ativismo transnacional apresentados por Khagram, Riker e Sikkink, a saber, redes sociais, coalizões sociais e movimentos sociais (2002: 7-8) e elas visarão os arranjos Estadocentrados e os arranjos privados de acordo com o próximo quadro. 
Tabela 2. Interação dos três níveis de ativismo sindical com o regime trabalhista internacional

\begin{tabular}{|c|c|c|c|c|c|c|c|c|c|}
\hline \multirow{2}{*}{$\begin{array}{c}\text { Níveis de } \\
\text { ativismo }\end{array}$} & \multicolumn{5}{|c|}{ REGIME TRABALHISTA INTERNACIONAL } \\
\cline { 2 - 9 } transnacional & OIT & OCDE & Nafta & Mercosul & UE & RSE & AMGs & Campanhas & PG \\
\cline { 2 - 9 } & & $\mathrm{X}$ & & & & $\mathrm{X}$ & & $\mathrm{X}$ & $\mathrm{X}$ \\
\hline Redes & & $\mathrm{X}$ & $\mathrm{X}$ & $\mathrm{X}$ & & & & $\mathrm{X}$ & \\
\hline Coalizões & $\mathrm{X}$ & & & $\mathrm{X}$ & $\mathrm{X}$ & & $\mathrm{X}$ & $\mathrm{X}$ & $\mathrm{X}$ \\
\hline Movimentos & $\mathrm{X}$ & $\mathrm{X}$ & & $\mathrm{X}$ & & & & & \\
Sociais & & & & & & & & & \\
\hline
\end{tabular}

Fonte: Elaboração própria.

Obs. (*) Nas colunas dos arranjos privados não foi incluída a SA 8000 por haver pouco acompanhamento social em relação ao mesmo e tampouco a ISO 26.000 por não estar em vigor ainda. No entanto, foi incluído o Pacto Global da ONU sob a sigla PG nesta coluna devido à ausência do arranjo Estado-centrado na sua gestão.

A interação apresentada esquematicamente entre o ativismo transnacional e as primeiras cinco colunas representa a estratégia dos atores sociais para convencer as OIs em questão ou utilizar seus arranjos para pressionar empresas a mudarem de atitude em relação ao regime trabalhista internacional e a interação com as quatro últimas colunas representa a incidência diretamente sobre as EMNs.

As táticas utilizadas variam de caso a caso desde a possibilidade de negociações puras e simples, até mobilizações que implicam em greves, boicote de consumo, bloqueio de circulação de mercadorias, entre outras. Porém, usualmente qualquer iniciativa começa pela "Advocacy" ou advocacia que defende uma solução para determinado problema inserido na causa ou missão onde determinado ator social atua. Para ser mais eficiente, a 
"Advocacy" necessita de publicidade para que obtenha o apoio da opinião pública a seu favor, pois as empresas que servem diretamente os consumidores com seus produtos, normalmente, tem muito zelo pela sua imagem, o que pode se tornar uma arma poderosa a favor do movimento social. Um exemplo do que isto significa foi o dano que a imagem da Ford do Brasil sofreu no final de 1998 quando às vésperas do Natal tentou demitir 2.800 empregados em São Bernardo do Campo de um total de 7.000. O movimento contrário desencadeado pelo sindicato teve total simpatia da opinião pública e as vendas da empresa despencaram.

Além da boa "Advocacy", comunicação eficiente e capacidade de mobilização é importante que os atores sociais que conduzem determinada causa também consigam constituir aliados na sociedade e nas esferas institucionais, bem como saber aproveitar determinada conjuntura favorável como a fórmula mencionada anteriormente por $\operatorname{Tarrow}^{27}$ para alcançar os resultados esperados.

Quanto a exemplos de redes de organizações sindicais e sociais que lidam com a promoção do regime trabalhista internacional podemos mencionar a "OECD Watch", a Rede Puentes, SIGTUR, Fundo de Greve da Toshiba, "Burma Campaign" e o "Global Compact Critics". A “OECD Watch" é uma rede de ONGs e organizações sociais de vários continentes que acompanham a política de investimentos promovida pela OCDE e o monitoramento das "Diretrizes para EMNs". A sua agenda neste sentido abarca direitos humanos, ambientais e também as Normas Fundamentais de Trabalho inseridas nas Diretrizes. A facilitação desta rede é feita por uma ONG holandesa conhecida como SOMO ("Centre for Research on Multinational Companies") e pelo acompanhamento feito até 2008 verificou-se que das 153 queixas recebidas pelos diferentes Pontos de Contatos

\footnotetext{
${ }^{27}$ Ver página 96.
} 
Nacionais 46 foram resolvidos, o que representa um índice de 30\% (SOMO, 2009). A mesma SOMO também coordena outra rede social chamada "Global Compact Critics" que como o nome sugere acompanha o comportamento trabalhista de algumas empresas que aderiram ao PG, mas que não cumprem algumas das normas previstas no Pacto. A elaboração da ISO 26.000 teve a participação de várias centrais sindicais de diferentes continentes, além da própria CSI e atualmente existe pelo menos uma rede de organizações sociais e sindicais que acompanha e promove a troca de informações sobre o tema responsabilidade social empresarial que é a Rede Puentes composta por organizações européias e latino-americanas. Este tema, na verdade ainda é pouco discutido pelo movimento sindical.

Por sua vez as redes que atuam nas campanhas em defesa do regime trabalhista são basicamente compostas por entidades sindicais como o Fundo de Greve da Toshiba organizado pela FITIM que regularmente coleta recursos financeiros de entidades filiadas a ela em diversos países e que representam trabalhadores desta empresa como forma de manter uma leve pressão permanente sobre a mesma. A "Burma Campaign" é uma rede de organizações sindicais, sociais e ONGs com sede na Inglaterra e que levanta recursos financeiros para sustentar a campanha pela democratização de Myanmar, troca informações sobre a situação política e social neste país e no campo sindical apóia a luta pela liberdade de associação, bem como o combate ao trabalho escravo mencionado anteriormente.

$\mathrm{O}$ "Southern Initiative on Globalization and Trade Union Rights" (SIGTUR) é uma iniciativa eminentemente sindical inaugurada no início dos anos 1990 quando houve uma greve nacional dos trabalhadores portuários na Austrália contra a reforma neoliberal da legislação trabalhista que afetaria o setor. Esta greve contou com a solidariedade prática dos portuários sul-africanos que se recusaram a carregar ou descarregar navios australianos 
enquanto ela durou e que terminou com o recuo do governo australiano em relação à reforma. Daí nasceu a iniciativa de se criar uma rede de centrais sindicais de países do Oceano Índico para trocar informações e promover campanhas de solidariedade geralmente nesta região. Hoje participam centrais sindicais da África do Sul, Austrália, Índia, Coréia do Sul, Filipinas, Indonésia, Tailândia, Hong-kong, entre outras (Webster e Lambert, 2005: 100).

É difícil apontar resultados concretos de transformação da realidade somente a partir da ação das redes, mas elas são fundamentais para alimentar atividades em níveis nacionais, dar publicidade internacional aos acontecimentos de determinado local e para romper o isolamento físico e psicológico de seus participantes. Já as coalizões normalmente vão mais longe como o já mencionado caso da Marcha Mundial Contra o Trabalho Infantil que levou à criação da Convenção 182 da OIT. Aliás, não se registram muitas incidências de atores sociais que não sejam de origem sindical ou empresarial sobre a OIT. As tentativas de coalizões sociais de influenciar processos Estado-centrados se ampliam um pouco em relação aos acordos de integração como o Nafta e o Mercosul. Quanto ao Nafta, o espaço buscado é basicamente o dos acordos paralelos e as centrais sindicais dos três países que nunca estabeleceram uma relação mais orgânica como, por exemplo, a Confederação Européia de Sindicatos, apresentaram algumas queixas contra EMNs com base no Acordo Trabalhista Paralelo, porém sem que isto gerasse soluções concretas, a não ser a má publicidade para algumas empresas em função das audiências públicas que foram promovidas. A Coalizão pela Justiça nas "maquillas" (CJM), uma coalizão com mais de cem membros entre sindicatos, ONGs, igrejas, entre outras organizações sociais do Canadá, EUA e México também atua por intermédio do Acordo Paralelo, além de se envolver diretamente na organização de trabalhadores neste tipo de empresas localizadas na fronteira 
do México com os Estados Unidos e que são isentas do pagamento de impostos e tampouco respeitam a legislação mexicana ambiental e trabalhista. Além da CJM existem outras iniciativas do gênero e algumas também atuam junto às "Maquillas" na América Central. A organização e mobilização dos trabalhadores em "maquillas" é muito difícil, pois um dos princípios de seu funcionamento é a ausência da gestão de relações regulares de trabalho que possam provocar o aumento do custo de mão de obra. Por isso, qualquer ativismo sindical ou social é reprimido pelas autoridades e pelas próprias empresas. Mesmo assim, chegam a ocorrer greves, como em 2001, numa "maquilla" da empresa americana Alcoa que montava rodas de automóveis em Ciudad Acuña no México, por aumento de salários e cumprimento da legislação trabalhista do país. Estes trabalhadores recebiam apoio internacional da central sindical americana AFL-CIO (Informação pessoal).

Existem comitês mundiais de sindicatos em várias EMNs, alguns deles reconhecidos como contrapartes pelas empresas para efeito de discussões de suas políticas globais como é o caso das multinacionais alemães Volkswagen e Mercedes Benz que inclusive bancam financeiramente as reuniões anuais dos membros dos respectivos comitês. No entanto este status é minoritário e em muitas empresas é necessário realizar duras e longas campanhas para obter reconhecimento e respeito aos direitos. A EMN brasileira Gerdau comprou recentemente algumas plantas siderúrgicas nos Estados Unidos e adotou uma postura totalmente anti-sindical recusando-se a renovar os contratos coletivos em algumas destas usinas e só mudou de atitude após a realização de uma campanha de denúncias públicas destas atitudes no Brasil, organizada pelo sindicato dos metalúrgicos dos EUA e Canadá e pelos metalúrgicos da CUT. Algo semelhante foi realizado na EMN gigante do setor de mineração, a Rio Tinto, com a participação de sindicatos da Austrália, Brasil, Canadá, Chile, Estados Unidos, Namíbia e Noruega para que ela reconhecesse todos os sindicatos e 
aceitasse negociar a renovação dos acordos coletivos de boa fé. A atitude das duas empresas mudou depois de algum tempo de pressão e passaram a negociar os contratos coletivos com os respectivos sindicatos normalmente.

Um dos casos mais emblemáticos ocorreu na indústria de calçados esportivos NIKE. Em 1996, uma ONG americana chamada "Global Exchange" começou a denunciar a NIKE nos EUA pelo uso de empresas subcontratadas na Indonésia que fabricavam os produtos desta empresa sob péssimas condições de trabalho e sem sequer pagar o salário mínimo local. A NIKE já havia retirado toda sua produção dos Estados Unidos alguns anos antes em busca de mão de obra mais barata e operava em Taiwan e na Coréia do Sul, mas na medida em que estes dois países se democratizaram e os sindicatos começaram a atuar livremente ela buscou outros nichos onde não enfrentasse este tipo de "problemas" e escolheu principalmente a Indonésia, Vietnã e China. Porém, as imagens mostradas ao público americano sobre a situação do trabalho na NIKE nestes países asiáticos repercutiu profundamente na opinião pública americana e a empresa começou a perder mercado para seus concorrentes. A partir de 1997 ela mudou de atitude, corrigindo vários dos problemas denunciados, como os baixíssimos salários e péssimas condições de saúde e segurança no trabalho. No entanto, tem sido necessário manter um acompanhamento permanente para que a situação não se deteriore novamente. O resultado positivo da campanha contra a NIKE inspirou a organização de uma coalizão permanente de organizações sindicais e ONGs para monitorar empresas do setor de calçados e vestuário que se chama "Clean Clothes Campaign" e que tem focado empresas como a C\&A, Adidas, Levi Strauss e outras (Werner e Weiss, 2006).

A campanha contra a NIKE também ensinou ao movimento social como as empresas quase sempre enfrentam da mesma maneira estas situações. Primeiramente negando que 
existe o problema e tentando provar que é uma boa empregadora. Quando não há como negar a realidade elas culpam terceiros como os fornecedores, os governos locais que não fiscalizaram, os empregados que não reclamaram e assim por diante, passando em seguida a acusar os denunciantes de terem uma agenda oculta de ordem política ou trabalhista e até ameaçando-os de processos judiciais. O quarto passo é tentar recuperar o controle da situação apresentando um código de conduta ou contratando assessoria especializada para, por fim, apresentar alguma coisa que aparente que a situação mudou. Esta última parte pode inclusive dividir a opinião do movimento social a depender da perspectiva de resultados que cada organização possuía. A NIKE chegou a contratar o ex-representante do governo Clinton junto a ONU, Andrew Young, para coordenar uma auditoria nas fábricas asiáticas. O seu parecer foi positivo à empresa, mas depois se verificou que sequer visitou as plantas pessoalmente. (IOS, 2003). O fato é que, mesmo alcançando mudanças nestas campanhas, é necessário manter a atenção sobre as empresas, pois o retrocesso é fácil.

O movimento sindical considerado a partir da perspectiva de terceiro nível de ativismo sindical mantém uma atitude mais de interação permanente e rotineira junto a OIs como a OIT por meio da CSI e das Federações Sindicais Internacionais e junto a União Européia e Mercosul, respectivamente por meio da CES e CCSCS. No que tange à interação com os arranjos privados, as FSIs apóiam as campanhas das coalizões quando estas se realizam como a CCC e também procuram ampliar o número de Acordos Marco Globais. Algumas ainda tentam monitorar as EMNs que aderiram ao Pacto Global da ONU como a ICEM em relação a empresa alemã BASF. No caso específico da União Européia há os Conselhos de Trabalhadores Europeus que envolvem aproximadamente 40.000 conselheiros atuando em aproximadamente 1.400 empresas que empregam em torno de 15 milhões de trabalhadores. Estes Conselhos são formalmente autônomos em relação aos 
sindicatos, mas em muitos casos trabalham juntos, o que aumenta o poder de negociação dos trabalhadores com as empresas, pois um dos direitos que os Conselhos possuem é o acesso às informações relacionadas à gestão empresarial. O Estatuto de funcionamento dos Conselhos é, no entanto, definido através de negociação com as empresas quando sua instalação é conquistada (Wills, 2001: 189).

Embora tenha havido muitas atuações conjuntas do movimento sindical com organizações sociais e ONGs frente às EMNs, isso não significa que as perspectivas de todos sejam atingidas, mesmo na hipótese de construção de boas práticas por parte de uma empresa. Por exemplo, a Stora Enso é uma EMN sueca/finlandesa do setor de papel e celulose e que tem demonstrado boa vontade para melhorar o cumprimento do regime trabalhista internacional, o que, no entanto, não é suficiente para algumas organizações de camponeses e ambientalistas porque estes querem a erradicação desta produção sob os argumentos da concentração de terra devido à plantação de eucaliptos e dos danos causados ao meio ambiente.

Existe uma atuação transnacional crescente do movimento social para assegurar maior respeito pelo regime trabalhista internacional. Percebe-se pelos exemplos utilizados neste capítulo (Tabela 2) que as organizações sindicais ainda seguem a tendência de ação preferencial junto às OIs ou então diretamente junto às empresas, neste caso, por intermédio dos Acordos Marco Globais e das campanhas dirigidas às EMNs, enquanto as organizações sociais e ONGs diversificam mais a sua atuação junto aos arranjos Estadocentrados e de algumas oportunidades que têm surgido nos arranjos privados, incluindo as campanhas junto às empresas.

\section{CONCLUSÃO}


Os dados apresentados nesta dissertação, mesmo com seu caráter não-exaustivo nos permite arriscar algumas afirmações. A primeira delas é que existe um regime internacional de trabalho basicamente Estado-centrado, que inclusive se ampliou ao envolver novas Organizações Internacionais no seu acompanhamento, e que é tanto mais forte na medida em que é acionado pelas organizações da sociedade como ONGs, sindicatos e empresas. No entanto, não se identifica quanto ao regime trabalhista internacional, a mesma percepção de importância e urgência junto à opinião pública que possuem os regimes de direitos humanos e o ambiental. Por exemplo, o acidente de vazamento de gás da empresa Union Carbide em Bhopal na Índia em 1984 causou entre 4 e 8 mil mortes e talvez seqüelas posteriores em outras 30 mil pessoas. Entre as primeiras vítimas, fatais ou não, do acidente estavam os trabalhadores da empresa, mas eles nunca são mencionados como tal.

Além disso, as tentativas dos empregadores para reduzir o alcance das normas na OIT ou para convencer outras OIs a estimular a flexibilização de direitos trabalhistas em nível nacional como ocorria intensamente por intermédio dos programas de ajuste estrutural do FMI, Banco Mundial e Bancos Regionais, principalmente, nos anos 1990 é outra comprovação que o regime trabalhista internacional existe e tem suas utilidades para os trabalhadores. Ninguém perderia tempo tentando desmontar ou neutralizar alguma coisa que fosse inócua. Quando a Convenção 177 sobre trabalho à domicílio foi adotada na Conferência Anual da OIT em 1996, no momento em que os representantes dos trabalhadores aplaudiam a sua aprovação na plenária final de delegados, a representante dos empregadores brasileiros indignada ironizava: “Isso! Engessa mais!” (Informação pessoal).

O aspecto privado do regime internacional de trabalho também está em processo de estabelecimento, embora ainda com muita deficiência quantitativa e qualitativa. $\mathrm{O}$ número de EMNs que desenvolvem arranjos de responsabilidade social empresarial para promover 
o respeito, no mínimo, pelas Normas Fundamentais de Trabalho nas suas cadeias produtivas ainda é pequeno diante do total mundial. Portanto, a incidência de uma política de garantia de direitos no PIB mundial é também pequena e aplicada ainda, na maioria das vezes, de forma unilateral. Se fosse mais discutida e negociada com as partes interessadas poderia ampliar sua qualidade e gerar processos de "spillover" (contágio) junto a outras empresas que não possuem políticas de RSE ainda, bem como da própria opinião pública.

Uma segunda afirmação decorrente das fontes da dissertação é a que da mesma forma que existe um regime trabalhista internacional, há um movimento sindical internacional, no entanto, de atuação cíclica com menos momentos de alta intensidade e vitórias e mais momentos de baixa atuação e posturas quando muito, defensivas. Apesar do declínio assinalado anteriormente em função das consequiências da globalização, percebe-se que há tentativas sérias de transitar do atual modelo de sindicalismo industrial para também incorporar os trabalhadores que pela natureza de suas relações de trabalho estão excluídos dos formatos tradicionais de contratação, bem como para ampliar as relações transnacionais, inclusive visando conquistar negociações coletivas em âmbitos supranacionais, conforme apresentado no terceiro capítulo.

No entanto, particularmente a mudança de paradigma de organização sindical nas bases nacionais, é um parto difícil e doloroso, mas não é a primeira vez que ocorre. Quando houve a mudança do paradigma de produção artesanal em fábricas ou oficinas relativamente pequenas para o modelo "Taylorista e Fordista" nas grandes indústrias, os sindicatos da época também tiveram dificuldades para se adaptar. Por exemplo, muitos dirigentes da "American Federation of Labor" (AFL) não acreditavam que os milhares de trabalhadores sem qualificação profissional, dos quais muitos sequer falavam inglês, trancados dentro das fábricas da indústria automobilística americana pudessem ser 
organizados e, por conseqüência, não permitiam que se sindicalizassem provocando uma cisão entre os sindicatos tradicionais e os sindicatos que se propuseram a organizar os trabalhadores inseridos no novo paradigma e que criaram outra central sindical na época, a “Confederation of Industrial Organizations". (Liechenstein, 1995). No entanto o modelo de organização sindical industrial é o que prevalece desde os anos 1930 até hoje e no caso do sindicalismo americano, a AFL e a CIO se unificaram em 1955, formando a atual AFLCIO.

Entretanto, já há iniciativas em vários países para organizar os trabalhadores informais e os que trabalham sob relações atípicas de trabalho como os imigrantes latinoamericanos em Los Angeles, os trabalhadores na construção civil da Holanda, os trabalhadores têxteis à domicílio na Austrália e no Canadá, os trabalhadores em empresas auto-gestionadas na Argentina, os trabalhadores na agricultura em Ghana, as mulheres que trabalham por conta própria na Índia e que possuem um dos maiores sindicatos do país, o "Self Employed Women Association - SEWA", entre outras experiências (Gallin, 2001: 234 $-237)$.

A mudança de paradigma produtivo demanda igualmente a mudança do paradigma organizativo, o que ainda não ocorreu, pelo menos, na dimensão necessária. Porém, existe a busca por novas formas de organização sindical, além das iniciativas em relação aos trabalhadores informais mencionadas acima, como, por exemplo, os "sindicatos comunitários" na Europa e Estados Unidos que envolvem toda uma comunidade com o trabalho sindical ao identificar e estabelecer uma agenda comum de trabalhadores e cidadãos (Early, 1998: 85 - 88).

Quanto ao novo paradigma de trabalho também já existem internacionalmente algumas iniciativas para lidar com isto no formato de redes de organizações sociais como o 
"Street Net" com sede na África do Sul que proporciona troca de informações, inclusive de experiências bem sucedidas de organização de associações, cooperativas e outras formas para que os trabalhadores na informalidade possam defender seus direitos e interesses.

Embora os sindicatos jamais aceitem ceder ou até mesmo compartilhar seu papel de negociador de contratos e relações de trabalho com outras organizações sociais ou ONGs há fartura de exemplos de cooperação e alianças com as mesmas. No caso mencionado dos trabalhadores indonésios da NIKE, quem assumiu em primeiro lugar a sua defesa foi uma ONG ("Global Exchange") até porque não havia sindicato local que pudesse ser cobrado a fazê-lo durante a ditadura do General Suharto naquele país. De qualquer maneira, embora os sindicatos possuam seu papel reconhecido institucionalmente, ninguém tem monopólio da defesa dos direitos humanos e trabalhistas.

Por fim, recuperando a discussão sobre o "bem comum" e os estímulos para as empresas cooperarem coletivamente ${ }^{28}$ percebe-se que isso abre uma janela de oportunidades, pois para as EMNs não há custos adicionais para cumprir o regime trabalhista e aquelas que trabalham diretamente para o público têm interesse em promover seu marketing, pois há faixas importantes dos consumidores que se importam com a "qualidade social" dos bens que adquirem. Porém, os consumidores necessitam de referências para confiar na informação de que esta qualidade efetivamente está sendo respeitada. Se as empresas aceitarem se submeter a monitoramento ou acompanhamento externo permanente, isto poderia ser a solução para garantir transparência. Num balanço feito pelo Instituto Observatório Social sobre o comportamento trabalhista de 40

\footnotetext{
${ }^{28}$ Ver página 123.
} 
subsidiárias de EMNs no Brasil pesquisadas por esta entidade ${ }^{29}$, bem como uma pesquisa especial que realizou em seis empresas onde estava garantida de antemão a cooperação das mesmas, verificou-se que quando os sindicatos souberam aproveitar a oportunidade nos casos em que as empresas se dispuseram a participar da pesquisa oferecendo informações, assegurando acesso aos locais de trabalho e discutindo os resultados foi possível progredir no cumprimento do regime de trabalho e estabelecer mecanismos mais perenes de monitoramento em quase metade delas (Barbosa, Veiga e Vilmar, 2006: 27).

O Estado possui a legitimidade para realizar este monitoramento pelos seus canais tradicionais de funcionamento como a fiscalização do trabalho, poder judicial, entre outros, mas o desafio é como estender isso para ser realizado também pelas partes interessadas. Os dados da avaliação acima representam uma amostra ínfima e imprecisa demais para se tornar um indicador quantitativo desta possibilidade, mas qualitativamente aponta para a existência de um potencial mínimo para a construção de relações de trabalho mais avançadas diante dos novos paradigmas econômicos e sociais por meio de um concerto envolvendo empresas e movimento social e sem depender exclusivamente dos arranjos de “cima para baixo" que são importantes, mas limitados.

\section{REFERÊNCIAS BIBLIOGRÁFICAS}

ALVES, J. A. L. Relações Internacionais e Temas Sociais: A Década das Conferências. Brasília: IBRI, 2001.

\footnotetext{
${ }^{29}$ A metodologia desta pesquisa é participativa envolvendo os sindicatos, bem como as empresas quando estas se dispõem a isso.
} 
AMOORE, L. Introduction: global resistance - global politics. In AMOORE, L. (Ed). The Global Resistance Reader. London: Routledge, 2005. p. 1 - 11.

ARRIGHI, G.; SILVER, B. Workers North and South. In AMOORE, L. (Ed). The Global Resistance Reader. New York: Routledge, 2005. p. 273 - 288.

BARBOSA, A. F.; JAKOBSEN, K. A. e BARBOSA, M. OMC, Desigualdade Norte/Sul e a Geopolítica do Desenvolvimento: As negociações do NAMA e os impactos sobre a América Latina e o Brasil. São Paulo: IOS, Mimeo, 2005.

BARbOSA, A. F.; VEIGA, J. P. C.; VILMAR, Maria Lúcia. O Monitoramento de Empresas Multinacionais no Brasil: um modelo de análise comparada. São Paulo: Mimeo, 2006.

BENDT, H. Um Mundo Uma Voz Solidaridad: Los Secretariados Profesionales Internacionales. Bonn: Friedrich Ebert Stiftung, 1996.

BOBBIO, N.; MATEUCCI, N.; PASQUINO, G. Dicionário de Política. Brasília: Editora UNB, 2004.

BRAVERMAN, H. Trabalho e capital monopolista: A Degradação do Trabalho no Século XX. Rio de Janeiro: Zahar Editores, 1981.

BRECHER, J.; COSTELLO, T.; SMITH, B. Globalization from below: the power of solidarity. Cambridge: South End Press, 2000. 
CASTELLS, M. A era da informação: Economia, sociedade e cultura Vol. 1 - A sociedade em Rede. São Paulo: Paz e Terra, 1999.

CHESNAIS, F. A mundialização do capital. São Paulo: Xamã, 1996.

CLAPP, J.; UTTING, P. Corporate Responsibility, Accountability and Law: an introduction. In CLAPP, J.; UTTING, P. (Org). Corporate Accountability and Sustainable Development. Oxford: University Press, 2008. p. 1 - 33.

COMPA, L. El Acuerdo de Cooperación Laboral del TLCAN: dimensión social o decepción social? In CASTRO, M. S. P. \& WACHENDORFER, A. (Org). Sindicalismo y globalización: la dolorosa inserción en un mundo incierto. Caracas: Editorial Nueva Sociedad, 1998. p. $59-86$.

COX, R. Civil society at the turn of the millenium: prospects of an alternative world order. In AMOORE, L. (Ed). The Global Resistance Reader. London: Routledge, 2005. p. $103-123$.

DOFNY, J. Os Sindicatos Americanos e a Automação. In RODRIGUES, L. M. Sindicalismo e sociedade. São Paulo: DIFEL, 1968. p. 159 - 177.

DRAZEN, A. Political economy in macroeconomics. New Jersey: Princeton University Press, 2000. 
DUPAS, G. Economia Global e Exclusão Social: Pobreza, Emprego, Estado e o Futuro do Capitalismo. São Paulo: Paz e Terra, 1999.

EARLY, S. Membership-based organizing. In MANTSIOS, G. (Ed.). A New Labor Movement for the New Century. New York: Monthly Review Press, 1998. p. 82 - 103.

ESTANQUE, E. A reinvenção do sindicalismo e os novos desafios emancipatórios: do despotismo local á mobilização global. In SANTOS, B. S. (Org.). Trabalhar o mundo: Os caminhos do novo internacionalismo operário. Rio de Janeiro: Civilização Brasileira, 2005. p. $357-401$.

FONOW, M. M.; FRANZWAY, S. Transnational union networks and labour advocacy. In SCHMIDT, V. (Ed). Trade Union Responses to Globalization. Genebra: OIT, 2007. p. 165 -175 .

GALLIN, D. Propositions on Trade Unions and Informal Employment in Times of Globalization. In WATERMAN, P.; WILLS, J. (Ed). Place, Space and the New Labour Internationalisms. Oxford: Blackwell Publishers Inc., 2001. p. 227 - 245.

GOHN, M. G. Teorias dos Movimentos Sociais: Paradigmas clássicos e contemporâneos. São Paulo: Edições Loyola, 1997.

GOHN, M. G. Novas Teorias dos Movimentos Sociais. São Paulo: Edições Loyola, 2008. 
GORZ, A. O despotismo de fábrica e suas conseqüências. In GORZ, A. (Org). Crítica da Divisão do Trabalho. São Paulo: Martins Fontes, 2001. p. 79 - 89.

GRAVEL, E.; DUPLESSIS, I.; GERNIGON, B. EI Comitê de Libertad Sindical: impacto desde su creación. Genebra: OIT, 2001.

HARVEY, D. La condición de la posmodernidad: Investigación sobre los orígenes des cambio cultural. Buenos Aires: Amorrortu editores, 2004.

HARVEY, D. A brief history of neoliberalism. Oxford: Oxford University Press, 2005.

HAAS, E. B. Words can hurt you; or, who said what to whom about regimes in KRASNER, S. D. (Org). International regimes. Ithaca: Cornell University Press, 1983. p. $23-59$.

HERON, C. The Canadian labour movement: a short story. Toronto: Lorimer, 1996.

HOBSBAWN, E. A era das revoluções. São Paulo: Paz e Terra, 1982.

HOBSBAWN, E. Mundos do trabalho. São Paulo: Paz e Terra, 1987.

HOBSBAWN, E. A Era dos Extremos: a história do mundo de 1914 a 1991. São Paulo: Companhia das Letras, 1994. 
IOS. Responsabilidade Social Empresarial: Perspectivas para a atuação sindical. São Paulo: Revista, 2004.

IRELA. A Sociedade Civil na América Latina e Caraíbas. Bruxelas: Relatório, 1999.

JAKOBSEN, K.; MARTINS, R.; DOMBROWSKI, O. O Mapa do Trabalho Informal: perfil sócio-econômico dos trabalhadores informais de São Paulo. São Paulo: Fundação Perseu Abramo, 2000.

JAKOBSEN, K. O monitoramento de empresas multinacionais. Montevidéu: FESUR, 2006.

KHAGRAM, S.; RIKER, J. V.; SIKKINK, K. From Santiago to Seattle: Transnational Advocacy Groups Restructuring World Politicas. In KHAGRAM, S.; RIKER, J. V.; SIKKINK, K. (Ed.). Restructuring World politics: Transnational Social Movements, networks and Norms. Minneapolis: University of Minnessota Press, 2002. p. 3 - 23.

KEOHANE, R. O.; NYE, J. S. Transnational relations and world politics. Cambridge: Harward University Press, 1971.

KRASNER, S. D. Structural causes and regime consequences: regimes as intervening variables. In KRASNER, S. D. (Org). International regimes. Ithaca: Cornell University Press, 1983. p. 1 - 21. 
KYLOH, R.; O’NEILL, F.; WHELTON, C. Los sindicatos y la economia global: una historia inconclusa. Genebra: Educación Obrera 2001/3-4, No. 124 - 125, OIT, 2001.

LICHTENSTEIN, N. Walter Reuther: The most dangerous man in Detroit. New York: Basic Books, 1995.

LINK, A. S.; CATTON, W. B. História moderna dos Estados Unidos. Rio de Janeiro: Zahar, 1965.

MARCUSSE, H. Estudos sobre a ideologia da sociedade industrial: o homem unidimensional. Rio de Janeiro: Zahar Editores, 1967).

MARGLIN, S. Origem e funções do parcelamento das tarefas (Para que servem os patrões?). In GORZ, A. (Org). Crítica da Divisão do Trabalho. São Paulo: Martins Fontes, 2001. p. $37-77$.

MARTIN, H. P.; SCHUMANN, H. A armadilha da globalização: O assalto à democracia e ao bem estar social. São Paulo: Editora Globo, 1996.

MARTINEZ, L. M. H. Comercio justo y derechos sociales: La condicionalidad social en el comercio internacional. Madrid: Tecnos, 2002.

MARX, K. O Capital: Crítica da economia política. Livro Primeiro, O processo de produção do capital. Rio de Janeiro: Civilização Brasileira, 2008. 
MASI, D. O futuro do trabalho: Fadiga e ócio na sociedade pós-industrial. Rio de Janeiro: José Olympio, 1999.

MENESCAL, A. K. História e Gênese das Organizações Não-Governamentais. São Paulo: estação Liberdade, 1996.

MITCHELL, R. B. Regime design matters: International Oil Pollution and Treaty Compliance. In KRATOCHWIL, F.; MANSFIELD, E. D. (Org). International organization and global governance: a reader. New York: HarperCollins College Publishers, 1994.

MUNCK, R. Globalisation and Labour: The new "Great Transformation". Londres: Zed Books, 2002.

NAPOLEONI, C. Smith, Ricardo, Marx. Rio de Janeiro: Graal, 2000.

NASSER, S. H. Desenvolvimento, Costume Internacional e Soft Law. São Paulo: Mimeo, 2002.

OFFE, C. La sociedad del trabajo: Problemas estructurales y perspectivas de futuro. Madrid: Alianza Universidad, 1984. 
OIT. Las normas internacionales del trabajo: Manual de educación obrera. Genebra: Oficina Internacional del Trabajo, 1998.

OLIVEIRA, M. F. Mercosul: atores políticos e grupos de interesse brasileiros. São Paulo: Editora UNESP, 2003.

PEASE, K. K. S. International Organizations: Perspectives on Governance in the twenty - first century. New Jersey: Prentice Hall, 2003.

POCHMANN, M. O emprego na globalização: A nova divisão do trabalho e os caminhos que o Brasil escolheu. São Paulo: Boitempo Editorial, 2001.

POCHMANN, M.; BORGES, A. “Era FHC”: A Regressão do Trabalho. São Paulo: Anita Garibaldi, 202.

POLANYI, K. La gran transformación. México: Juan Pablos Editor, 2009.

PINTO, G. A. A organização do trabalho no século 20: Taylorismo, Fordismo e Toyotismo. São Paulo: Editora Expressão Popular, 2007.

RATHGEBER, T. UN Norms on the Responsabilities of Transnational Corporations. Genebra: Revista Dialogue on Globalization da Friedrich Ebert Stiftung, No 22, 2006. 
RIFKIN, J. Fim dos empregos: O declínio inevitável dos níveis dos empregos e a redução da força global de trabalho. São Paulo: Makron Books, 1995.

RISSE, T. Transnational Governance and Legitimacy. Den Haag: Mimeo, 2004.

RISSE-KAPPEN, T. Bringing transnational relations back in: introduction. In Bringing transnational relations back: Non-state actors, domestic structures and international institutions. RISSE-KAPPEN, T (Ed.). New York: Cambridge University Press, 1995. p. 3 -33 .

ROSENAU, J. N. Governança, ordem e transformação na política mundial. In ROSENAU, J. N. e CZIEMPEL, E. O. (Org). Governança sem governo: ordem e transformação na política mundial. Brasília: Editora UNB, 2000. p. 11 - 46.

ROSENAU, J. Governance in the Twenty First Century. In WILKINSON, R. The Global Governance Reader. London: Routledge, 2005. p. 45 - 67.

RUGGIE, J. G. International regimes, transactions, and change: embedded liberalism in the postwar economic order. In KRASNER, S. D. (Org). International regimes. Ithaca: Cornell University Press, 1983. p. 195 - 231. 
RUGGIE, J. G.. Interim Report of the Special Representative of the Secretary-General on the Issue of Human Rights and Transnational Corporations and Other Business Enterprises. Minneapolis: Mimeo, 2006 (a). p. 21. U.N. Doc. E/CN.4/2006/97.

RUGGIE, J. G. Human Rights Policies and Management Practices of Fortune Global 500 Firms: Results of a Survey. Cambridge: Mimeo, 2006(b). p. 25. A/HRC/4/74.

SASSOON, D. One Hundred Years of Socialism: The West European Left in the Twentieth Century. Londres: Fontana Press, 1997.

SANTANIELLO, R. El Mercado único europeo. Madri: Acento Editorial, 1999.

SCHERRER, C.; GREVEN, T. Global rules for trade: codes of conduct, social labeling, workers rights clauses. Münster: Westfälisches Dampfboat, 2001.

SPOONER, D. Labor Unions and NGOs: The Need for Cooperation. In EADE, D.; LEATHER, A. Development NGOs and Labor Unions: Terms of Engagement. Bloomfield: Kumarian Press. Inc., 2005.

TEITELBAUM, A. Observaciones al Informe del Señor John Ruggie Representante Especial del Secretario general sobre la Cuestión de los Derechos Humanos y las Sociedades Transnacionales. Lyon: Mimeo, 2006. 
TARROW, S. The New Transnational Activism. New York: Cambridge University Press, 2005.

TUAC. Diretrizes da OCDE para Empresas Transnacionais: Guia do Usuário. Paris: TUAC, 2002.

YOUNG, O. R. Regime dynamics: the rise and fall of international regimes. In KRASNER, S. D. (Org). International regimes. Ithaca: Cornell University Press, 1983. p. $93-113$.

VIEIRA, L. Os argonautas da cidadania: A sociedade civil na globalização. Rio de Janeiro: Editora Record, 2001.

WEBSTER, E.; LAMBERT, R. Emancipação social e o novo internacionalismo operário: uma perspectiva do Sul. In SANTOS, B. S. (Org.). Trabalhar o mundo: Os caminhos do novo internacionalismo operário. Rio de Janeiro: Civilização Brasileira, 2005. p. $79-133$.

WERNER, K.; WEISS, H. El libro negro de las marcas. Barcelona: DeBolsillo, 2006.

WILLS, J. Uneven Geographies of Capital and Labour: The lessons of European Works Councils. In WATERMAN, P.; WILLS, J. (Ed). Place, Space and the New Labour Internationalisms. Oxford: Blackwell Publishers Inc., 2001. p. 180 - 205. 
WILSON, E. Rumo à Estação Finlândia. São Paulo: Companhia das Letras, 2006.

\section{Websites:}

ABONG,

2009.

Disponível

em:

<http://www2.abong.org.br/final/livros/php?cd_materia=18034\#0\%20que\%20é> visitado em 15/07/2009.

Burmacampaign, 2009. Disponível em: <http://www.burmacampaign.org.uk> visitado em $15 / 07 / 2009$

Csrnetwork, 2009. Disponível em: <http://www.csrnetwork.com/story.asp?id=112> visitado em 15/07/2009.

OCDE,

2009.

Disponível

em:

<http://www.oecd.org/findDocument/0,3354en_2649_34889_1_1_1_1_1,00.html> visitado em 20/07/2009.

OIT, 2008. Disponível em: <http://www.ilo.org> visitado em 03/12/2008.

OIT, 2009a. Disponível em: <http://www.ilo.org> visitado em 03/07/2009.

OIT, 2009b. Disponível em: <http://www.ilo.org> visitado em 03/07/2009.

OMC, 2009. Disponível em: <http://www. wto.org> visitado em 03/07/2009. 
SAI, 2009a. Disponível em: <http://www.sa-intl.org> visitado em 20/07/2009.

SAI, 2009b. Disponível em: <http://www.saasaccreditation.org/certfacilitieslist.htm> visitado em 20/07/2009.

Unctad, $2008 . \quad$ Disponível em: <http://www.unctad.org/Templates/Webflyer.asp?intItemID=4629\&lang=1> visitado em $8 / 12 / 2008$. 